RICARDO BASILE PUCCI

\title{
LOGÍSTICA DE RESÍDUOS DA CONSTRUÇÃO CIVIL ATENDENDO À RESOLUÇÃO CONAMA 307
}

\author{
Dissertação apresentada à Escola \\ Politécnica da Universidade de São \\ Paulo para a obtenção do Título de \\ Mestre em Engenharia.
}




\title{
LOGÍSTICA DE RESÍDUOS DA CONSTRUÇÃO CIVIL ATENDENDO À RESOLUÇÃO CONAMA 307
}

\author{
Dissertação apresentada à Escola \\ Politécnica da Universidade de São \\ Paulo para a obtenção do Título de \\ Mestre em Engenharia \\ Área de Concentração: \\ Engenharia de Sistemas Logísticos \\ Orientador: \\ Prof. Dr. Nicolau Dionísio Fares Gualda
}

São Paulo

2006 
Este exemplar foi revisado e alterado em relação à versão original, sob responsabilidade única do autor e com a anuência de seu orientador.

São Paulo, 18 de junho de 2006.

Assinatura do autor

Assinatura do orientador

FICHA CATALOGRÁFICA

Pucci, Ricardo Basile

Logística de resíduos da construção civil atendendo à resolução CONAMA 307 / R.B. Pucci. -- ed.rev. -- São Paulo, 2006.

$137 \mathrm{p}$.

Dissertação (Mestrado) - Escola Politécnica da Universidade de São Paulo. Departamento de Engenharia de Transportes.

1.Logística (Adminsitração de materiais) 2.Simulação 3.Resíduos de cosntrução 4.Reciclagem de resíduos urbanos I.Universidade de São Paulo. Escola Politécnica. Departamento de Engenharia de Transportes II.t. 
AUTORIZO A REPRODUÇÃO E DIVULGAÇÃO TOTAL OU PARCIAL DESTE TRABALHO, POR QUALQUER MEIO CONVENCIONAL OU ELETRÔNICO, PARA FINS DE ESTUDO E DE PESQUISA, DESDE QUE CITADA A FONTE. 
Ao meu pai e minha irmã 


\section{AGRADECIMENTOS}

Agradeço a todos meus colegas da Escola Politécnica, pelas numerosas horas de estudo e dedicação que passamos juntos.

Aos meus professores, que participaram de uma formação que se mostrou muito mais do que acadêmica. Em especial ao meu orientador, Prof. Dr. Nicolau D. F. Gualda, que desde a graduação até hoje sempre ofereceu seu conhecimento, compreensão e apoio.

Ao Prof. Dr. Vanderley M. John, que me auxiliou muito nas partes do trabalho que envolviam Construção Civil, bem como fazendo sempre questionamentos pertinentes sobre a logística envolvida.

Ao Sinduscon SP, em especial Lilian Sarrouf, pelo imenso apoio e por permitir minha presença no Grupo de Trabalho de Gestão de Resíduos.

A Élcio Carelli, pelo ensinamento prático passado.

A Ricardo Pina, pelas discussões sempre produtivas e por fornecer, sempre de forma ágil, todos os dados que solicitei.

Por fim, a minha família, futura esposa e amigos, que sempre entenderam meus exílios de estudo e que sempre me incentivaram quando esse apoio era o mais necessário. 
"Os homens tropeçam por vezes na verdade, mas a maior parte torna a levantar-se e continua depressa o seu caminho, como se nada tivesse acontecido".

Sir Winston S. Churchill (1874 - 1965) 


\section{RESUMO}

O Resíduo de Construção e Demolição (RCD), devido ao seu volume, gera um alto impacto ambiental, social e econômico, trazendo assim a preocupação crescente sobre sua gestão.

Essa gestão sempre foi responsabilidade do poder público. Porém, com a Resolução 307 do Conselho Nacional do Meio Ambiente (CONAMA), de 05 de julho de 2002, ela foi transferida para os geradores de resíduos, que devem segregar o resíduo em quatro classes diferentes e encaminhá-las para reciclagem ou deposição final.

Assim, este trabalho propõe uma metodologia, baseada no enfoque sistêmico e em técnicas de pesquisa operacional, para tratar o problema de gestão de resíduos da Construção Civil, em conformidade com a Resolução CONAMA 307.

A metodologia proposta compreende a elaboração de um Plano de Gestão de Resíduos que contemple a fase de projeto, minimizando a geração de resíduos; a segregação e o transporte do resíduo gerado dentro da obra; e a sua destinação final, incluíndo o controle da segregação e deposição do resíduo gerado.

No trabalho são comparadas duas obras, uma onde não houve nenhuma forma de gestão sobre o resíduo e outra onde o Plano de Gestão proposto foi aplicado. Além disso, foi feito um modelo de simulação utilizando o programa de computador Arena 7.0, utilizado para avaliação do impacto do Plano em diversos cenários de geração, segregação e transporte dos resíduos.

Como resultado do trabalho apresenta-se um Plano de Gestão de Resíduos que possui viabilidade econômica, social e ambiental, além de ser legalmente adequado, para ser usado por profissionais do setor público e privado no tratamento e gestão do resíduo gerado em suas obras. 


\section{ABSTRACT}

The Construction and Demolition Waste (C\&DW), because of its high volume, brings high environmental social and economical impacts, therefore the worries about its management has grown.

This management has always been responsibility of the governments. But with the Resolution 307 of CONAMA (Brazilian Environmental National Council) of July $22^{\text {nd }}$, 2002 , it was transferred to the waste producer, which has to segregate it in four different categories and ship it to be recycled or disposed properly.

The proposal is to create a method, based on system approach and operations research, to deal with C\&DW management, respecting Resolution 307 guidelines.

The proposed method encompasses the creation of a Waste Management Plan, which considers the aspects of the project, to minimize waste generation; the segregation and transport within the construction site; and the final destination of the waste, including a method to control its segregation and shipping.

Two construction sites were considered, one that did not have any kind of waste management and one on which the Management Plan was implemented. In addition, it was developed a simulation model using the computer software Arena 7.0, to analyze the Plan under different scenarios of generation, segregation and shipping of construction waste.

As a result, a Plan of C\&DW Management was proposed and validated, which is economic, social and environmental feasible and legally adequate, to be used by public and private professionals when dealing with the C\&DW of their constructions. 


\section{LISTA DE FIGURAS}

Figura 2.1. Comparação entre Logística Reversa e Logística "Verde” 22

Figura 3.1. Possibilidades de separação do resíduo 35

Figura 3.2. Ciclo de transporte do resíduo 36

Figura 3.3. Blocos de encaminhamento dos resíduos no modelo 37

Figura 4.1. Bombonas $\quad 52$

Figura 4.2. Bags $\quad 52$

Figura 4.3. Baias $\quad 52$

Figura 4.4. Duto para Classe A 53

Figura 4.5. Separação e transporte dos resíduos dentro da obra 54 Figura 6.1. Representação da preparação do terreno e fundações do
Edifício Piloto

Figura 6.2. Representação de um andar do Edifício Piloto 71

Figura 6.3. Representação da retirada de resíduos 78

Figura 6.4. Representação dos contadores $\quad 81$

Figura 6.5. Representação dos gravadores read write 83

Figura 6.6. Visualizadores Intermediários $\quad 84$

Figura 6.7. Visualizadores finais $\quad 85$ 


\section{LISTA DE GRÁFICOS}

Gráfico 5.1. Avaliação de Limpeza e Segregação 62

Gráfico 7.1. Geração diária de madeira no Modelo 90

Gráfico 7.2. Geração diária de mineral no Modelo $\quad 91$

Gráfico 7.3. Geração diária de terra no Modelo 91

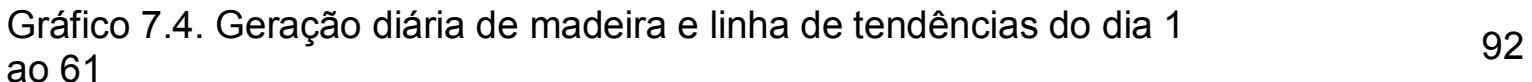

Gráfico 7.5. Geração diária de madeira e linha de tendências do dia 6293 ao 251

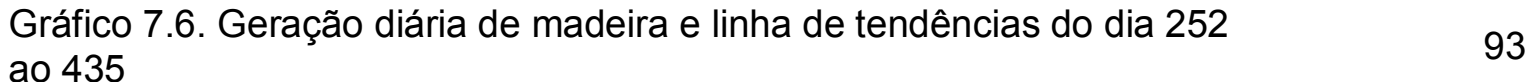

Gráfico 7.7. Geração diária de madeira e linha de tendências do dia 436 ao 615

Gráfico 7.8. Geração diária de mineral e linha de tendências do dia 62 ao 251

Gráfico 7.9. Geração diária de mineral e linha de tendências do dia 252 ao 435

Gráfico 7.10. Geração diária de mineral e linha de tendências do dia 436 ao 615

Gráfico 7.11. Geração diária de terra e linha de tendências do dia 1 ao 61

Gráfico 7.12. Geração diária de terra e linha de tendências do dia 62 ao 245

Gráfico 7.13. Geração acumulada de papel Real X Modelo 100

Gráfico 7.14. Geração acumulada de plástico Real X Modelo 100

Gráfico 7.15. Geração acumulada de metal Real X Modelo 101

Gráfico 7.16. Geração acumulada de madeira Real X Modelo 101

Gráfico 7.17. Geração acumulada de mineral Real X Modelo 102

Gráfico 7.18. Geração acumulada de terra Real X Modelo 102 


\section{LISTA DE TABELAS}

Tabela 4.1. Divisão de Procedimentos na Construtora 49

Tabela 5.1. Resíduos no Edifício Piloto $\quad 57$

Tabela 5.2. Conversão de quilo para metro cúbico 58

Tabela 5.3. Resíduos do Edifício Piloto em metros cúbicos 58

Tabela 5.4. Resíduos no Edifício Controle 58

Tabela 5.5. Comparativo de densidades de parede e área molhada 59

Tabela 5.6. Comparativo de geração de resíduos por volume 60

Tabela 5.7. Conversão de metros cúbicos para quilo 60

Tabela 5.8. Cálculo da geração de resíduos em $\mathrm{kg} / \mathrm{m}^{2}$ - Ed. Controle 60

Tabela 5.9. Cálculo da geração de resíduos em $\mathrm{kg} / \mathrm{m}^{2}-$ Ed. Piloto 61

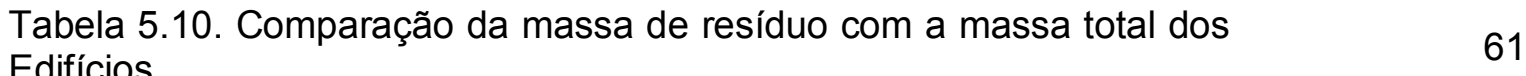

Tabela 5.11. Valores de venda dos resíduos recicláveis 63

Tabela 5.12. Custos do Edifício Piloto 64

Tabela 5.13. Comparação de notas de limpeza e segregação 65

Tabela 7.1. Dados de entrada para verificação 88

Tabela 7.2. Dados de entrada da Simulação 2

Tabela 7.3. Dados de entrada da Simulação $3 \quad 89$

Tabela 7.4. Dados de entrada da Simulação 4

Tabela 7.5. Resultado da verificação do modelo 99

Tabela 7.6. Resultado das simulações 103

Tabela 7.7. Resultado do agendamento para madeira - política 1

Tabela 7.8. Resultado do agendamento para madeira - política 2

Tabela 7.9. Resultado do agendamento para mineral - política 1

Tabela 7.10. Resultado do agendamento para mineral - política $2 \quad 106$

Tabela 7.11. Resultado do agendamento para terra 107 


\section{SUMÁRIO}

INTRODUÇÃO

CAPÍTULO 1. CARACTERIZAÇÃO DA CADEIA LOGÍSTICA DO RESÍDUO DE CONSTRUÇÃO E DEMOLIÇÃO

1.1. Introdução

1.2. Subsistema Interno à Obra 2

1.3. Subsistema Externo à Obra 3

1.4. Abordagem à Cadeia Logística do RCD 4

1.5. Conclusão do Capítulo 5

CAPÍTULO 2. REVISÃO BIBLIOGRÁFICA 6

2.1. Introdução 6

$\begin{array}{ll}\text { 2.2. Revisão da Legislação } & 7\end{array}$

2.2.1. Enfoque Logístico da Legislação 9

2.3. Perdas e Produtividade na Construção Civil 11

2.3.1. Perdas na Construção Civil 12

2.3.2. Produtividade na Construção Civil 14

2.4. Práticas Anteriores 15

2.5. Experiências Internacionais 17

2.6. Enfoque ao Problema 19

2.6.1. Enfoque Sistêmico 19

2.6.2. Logística Reversa e Logística "Verde" 21

2.6.3. Técnicas de Pesquisa Operacional 23

2.6.4 Simulação e a Utilização do Programa Arena 7.0 24

2.7. Conclusão do Capítulo 26

CAPÍTULO 3. METODOLOGIA ADOTADA 27

$\begin{array}{ll}\text { 3.1. Introdução } & 27\end{array}$ 
$\begin{array}{ll}\text { 3.2. Enfoque Sistêmico } & 27\end{array}$

3.2.1. Objetivo e Medidas de Efetividade $\quad 27$

3.2.2. Ambiente e Recursos do Problema 29

3.2.3. Componentes do Problema e sua Administração 29

3.3. Geração e Avaliação de Alternativas 30

3.4. Caracterização do Problema 33

3.4.1. Redução do Resíduo 33

3.4.2. Tratamento Dentro da Obra 34

3.4.3. Destinação Final do Resíduo 36

3.5. Modelo de Simulação 37

3.6. Conclusão do Capítulo 39

CAPÍTULO 4. APLICAÇÃO EM UM CASO 40

4.1. Introdução 40

4.2. Nível Estratégico $\quad 41$

$\begin{array}{ll}\text { 4.3. Nível Tático } & 42\end{array}$

4.3.1. Alterações no Projeto 43

4.3.2. Métodos Construtivos 44

4.3.3. Determinação de Responsabilidades $\quad 47$

4.3.4. Conscientização dos Funcionários 49

4.4. Nível Operacional

4.5. Controle de Adequação dos Procedimentos 54

4.6. Materiais sem Destinação Definida 55

4.7. Conclusão do Capítulo 56

CAPÍTULO 5. RESULTADOS DA APLICAÇÃO EM UM CASO 57

5.1. Introdução $\quad 57$

5.2. Resultados $\quad 57$

5.3. Análise dos Objetivos $\quad 59$ 
$\begin{array}{ll}\text { CAPÍTULO 6. MODELAGEM } & 67\end{array}$

6.1. Introdução $\quad 67$

6.2. Modelo do Edifício Piloto $\quad 67$

6.2.1. Modelagem da Preparação do Terreno e Fundações e dos 68 Pavimentos

6.2.2. Modelagem dos Pavimentos 70

6.2.3. Modelagem da Retirada de Resíduo dos Andares 73

6.2.4. Modelagem da Retirada de Resíduos da Obra 76

6.2.5. Sistema de Contadores 80

6.2.6. Gravadores de Dados read write 82

6.2.7. Visualizadores Intermediários 84

6.2.8. Visualizadores Finais 85

6.3. Conclusão do Capítulo 86

CAPÍTULO 7. SIMULAÇÕES DO EDIFÍCIO PILOTO 87

$\begin{array}{ll}\text { 7.1. Introdução } & 87\end{array}$

7.2. Simulação 1: Verificação da Simulação com Dados da 88

7.3. Simulação 2: Ed. Piloto sem Redução nem Segregação do 89

7.4. Simulação 3: Ed. Piloto sem Redução e com Segregação do 89

Resíduo

7.5. Simulação 4: Ed. Piloto com Redução e sem Segregação do 90

7.6. Simulação 5: Novo Modelo de Retirada de Resíduos 90

7.6.1. Retirada da Madeira 92

7.6.2. Retirada do Mineral 94

$\begin{array}{ll}\text { 7.6.3. Retirada da Terra } & 97\end{array}$

7.7. Resultado das Simulações da Efetividade do Plano de Gestão 99

7.8. Resultado das Simulações do Novo Modelo de Retirada de
Resíduos 
7.8.1. Retirada da Madeira

104

7.8.2. Retirada da Mineral

106

7.8.3. Retirada da Terra

107

7.9. Conclusão do Capítulo

CAPÍTULO 8. CONCLUSÃO, COMENTÁRIOS E RECOMENDAÇÕES

ANEXOS

Anexo I

113

Anexo II

126

Anexo III

128

Anexo IV

129

Anexo V

130

Anexo VI

131

BIBLIOGRAFIA 


\section{INTRODUÇÃO}

A preocupação no Brasil com resíduos sólidos tem crescido nos últimos anos. Ela tem sido tratada por diversas leis, projetos de lei e resoluções que definem, classificam e dão diretrizes para a gestão dos resíduos sólidos. Dentre esses resíduos, está o gerado pela indústria da construção civil, classificado como resíduo urbano especial (CARDOSO, 2003). Nesse aspecto, além de cumprir a legislação referente aos resíduos sólidos, os resíduos de construção e demolição (RCD) estão sujeitos a legislações específicas no âmbito federal, estadual e municipal.

Historicamente, o RCD sempre foi depositado em aterros públicos ou, de forma muito mais danosa à sociedade, em bota-foras ilegais, ou mesmo em canteiros de avenidas, praças e ruas. O volume de RCD pode representar $67 \%$ dos resíduos sólidos urbanos (JOHN, 2000b). A responsabilidade de destinar corretamente essa massa sempre foi da administração pública, que era responsável não só pelos aterros regulamentados, como também pela limpeza do RCD depositado ilegalmente em canteiros, avenidas e praças.

Nos últimos anos, a consciência de que essa responsabilidade seria do poder público transformou-se, sendo hoje considerado que o gerador é responsável pelo RCD, enquanto a responsabilidade do poder público se resume em regulamentar, fiscalizar e possibilitar seu destino correto. Essa mudança fica clara, e é regulamentada, pela Resolução 307 do Conselho Nacional do Meio Ambiente, de 5 de julho de 2002, que estabelece diretrizes, critérios e procedimentos para a gestão dos resíduos da construção civil.

Dessa forma, o objetivo desse trabalho é propor uma metodologia para a Gestão de Resíduos de Construção Civil em canteiros, adequando-se à nova Resolução CONAMA 307. Essa metodologia será baseada em ferramentas e conhecimentos de Logística, no enfoque sistêmico, técnicas de pesquisa operacional e simulação, com o objetivo de analisar, quantificar e simular diferentes cenários para otimizar essa Gestão. 


\section{CAPÍTULO 1. CARACTERIZAÇÃO DA CADEIA LOGÍSTICA DO RESÍDUO DE CONSTRUÇÃO E DEMOLIÇÃO}

\subsection{INTRODUÇÃO}

A cadeia logística do RCD pode ser dividida em dois subsistemas distintos, que merecem tratamentos específicos, já que incluem diferentes participantes e etapas em cada um deles. Esses dois subsistemas podem ser divididos fisicamente entre a parte da cadeia logística que acontece internamente à área da obra, e aquela que ocorre externamente à mesma.

\subsection{SUBSISTEMA INTERNO À OBRA}

O primeiro subsistema é o interno à obra, que trata do resíduo gerado por uma tarefa específica, sua segregação, seu acondicionamento no local da tarefa, seu transporte até o local de armazenagem da obra e armazenagem até a sua retirada.

Qualquer influência ou ação que seja necessária nesse subsistema é responsabilidade da Construtora, através de sua equipe, ou então de subempreiteiros contratados por ela. Os fatores externos que podem afetar esse subsistema são principalmente dois: o legal e a armazenagem para retirada do resíduo.

O aspecto legal não determina diretamente como o resíduo deve ser tratado nesse subsistema, porém indica, de forma indireta, como ele deve ser processado. Mudanças na legislação, como a Resolução CONAMA 307, que será detalhada no próximo capítulo, alteram a forma de reaproveitamento e deposição final do RCD, o que acaba interferindo no tratamento e no transporte dentro da obra.

A forma de armazenagem também tem influência externa, já que cada resíduo tem seu modo específico de ser retirado, e a quantidade de equipamentos de armazenagem é definida pela freqüência de retirada do resíduo. Essa etapa funciona como o ponto de 
intersecção entre os dois subsistemas, sendo a última etapa do primeiro e a primeira do segundo.

\subsection{SUBSISTEMA EXTERNO À OBRA}

O subsistema externo à obra compreende as etapas de armazenagem do resíduo para retirada, o transporte do resíduo e sua deposição final. Esse subsistema se apresenta de forma muito mais complexa que o primeiro, já que a responsabilidade por cada etapa pertence a diferentes interlocutores.

A etapa de armazenagem para retirada, como dito no item anterior, é de responsabilidade da Construtora, porém sujeita a definições legais e de transporte.

Já a etapa de transporte tem como interlocutores as empresas removedoras de resíduos. Apesar desse mercado ser regulado pelas prefeituras através do cadastramento das empresas, existe uma alta taxa de informalidade no setor, além de alta rotatividade, com um grande índice de fechamento e abertura de novas empresas. Como exemplo, na cidade de São Paulo, existem cadastradas 370 empresas no Limpurb (Departamento de Limpeza Urbana da Secretaria de Serviços e Obras), que oferecem aproximadamente 13.000 caçambas (LIMPURB, 2005a). Porém, a estimativa é que mais de 700 empresas atuam no município (BARBOSA, 2003), o que significa um índice de informalidade de quase cinqüenta por cento.

A deposição final dos resíduos deve ser feita necessariamente em locais que possuam licença para receber resíduos de construção e demolição. Esse é outro aspecto que agrega dificuldade ao processo, já que existem poucas áreas regularizadas. Usando novamente o município de São Paulo como exemplo, existem apenas três áreas com licença de funcionamento cadastradas na Limpurb (LIMPURB, 2005b), que teoricamente devem atender a todo o município. Na prática, existem diversos aterros ilegais espalhados pela Grande São Paulo, que acabam suprindo a necessidade de espaços para a deposição desse material. 
Apesar do município ser responsável por legalizar essas áreas, atualmente existe um grande entrave burocrático nesse processo que acaba desestimulando a regularização de áreas ilegais utilizadas atualmente como aterro.

\subsection{ABORDAGEM À CADEIA LOGÍSTICA DO RCD}

Analisando as características dos subsistemas da cadeia logística do Resíduo de Construção e Demolição, fica claro que uma Construtora deve concentrar seus esforços no primeiro subsistema. Isso porque é nesse subsistema que sua margem de atuação sofre menos interferência de outros agentes.

Dessa forma, a Construtora deve estabelecer metodologias para tratar internamente o resíduo por ela gerado da forma mais racional possível. De preferência, iniciando com um processo de diminuição da geração, diminuindo assim o tamanho do problema a ser gerenciado. Após isso, ela deve buscar formas de tratar esse resíduo e transportá-lo dentro de sua obra de forma que ele fique em condições que sejam condizentes com a legislação. Só depois disso é que agentes externos à obra participam da cadeia.

Apesar desse foco, o segundo subsistema não pode ser esquecido. É obrigação da Construtora contratar empresas removedoras legalizadas e depositar seu resíduo também de forma legal.

Para o transporte, existem os cadastros municipais de empresas legalizadas, como no município de São Paulo (LIMPURB, 2005a). Além disso, existem sindicatos dessa categoria, como o SIERESP (Sindicato da Empresas Removedoras de Entulho do Estado de São Paulo).

No quesito deposição, a atuação da Construtora pode se concentrar em três pontos: exigir que sua empresa removedora deposite o resíduo em local licenciado; tentar localizar pontos alternativos de recebimento, principalmente para o resíduo reciclável; atuar em conjunto ao sindicato patronal, no caso o Sinduscon (Sindicato da Indústria da Construção Civil), para exigir do poder público incentivo para regularização de novos pontos de deposição. 


\subsection{CONCLUSÃO DO CAPÍTULO}

Nesse Capítulo foi feita a caracterização da cadeia logística do RCD, dividindo-a em dois subsistemas: o interno e o externo à obra.

Como foi exposto, a abordagem de uma Construtora deve ocorrer no primeiro subsistema, o interno à obra, pois é nele que detém maior possibilidade de controle, com menor interferência de agentes externos.

Apesar disso, a Construtora deve estar ciente sobre as necessidades referentes ao subsistema externo. Entre elas, está a utilização de empresas de transporte e pontos de deposição regulamentados. 


\section{CAPÍTULO 2. REVISÃO BIBLIOGRÁFICA}

\subsection{INTRODUÇÃO}

A abordagem ao problema da Gestão de Resíduos da Construção Civil deve ser feita conforme indicado no Capítulo anterior, no subsistema interno à obra. Isso, porém, não exclui o conhecimento e a caracterização do problema como um todo, que é o objetivo deste Capítulo.

A bibliografia desse tema no Brasil é bastante restrita, já que esse é um assunto relativamente novo. O material disponível, apesar de sua ótima qualidade, possui um enfoque voltado, principalmente, para o tratamento do RCD por parte dos governos ou então para sua caracterização. Dessa forma, por maior complementação que exista, não corresponde ao objetivo deste trabalho, que é o de propor um Plano de Gestão de Resíduos para Construtoras. Ao mesmo tempo, as experiências internacionais, apesar de diversas, possuem um nível de sofisticação muito maior que o necessário no Brasil, tanto por questões legais como por custos elevados relacionados a material, mão-deobra e deposição final. De qualquer forma, essas experiências devem ser citadas e merecem um estudo específico posterior, devido ao seu volume, de como adequá-las a realidade brasileira.

Assim, essa Revisão Bibliográfica possui seu foco no Estudo da Legislação e seu impacto logístico, passando para o Estudo das Perdas e Produtividade da Construção Civil, onde se analisam os principais fatores de influência nesses itens; segue depois com os seguintes tópicos: Práticas Anteriores do Mercado, onde é feito um pequeno resumo das ações tomadas anteriormente pela Indústria da Construção Civil no tratamento do resíduo; Experiências Internacionais, que resume algumas experiências para o tratamento de resíduos no mundo; e o Enfoque ao Problema, onde serão apresentadas as ferramentas a serem utilizadas para enfrentar os desafios logísticos da Gestão do RCD. 


\subsection{REVISÃO DA LEGISLAÇÃO}

A principal revisão bibliográfica necessária é no assunto que, na verdade, influencia todo o estudo: a legislação. Pelo fato da Gestão de Resíduos ser motivada, acima de tudo, por uma imposição legal, surge a necessidade de entender em detalhes a resolução CONAMA 307 (2002) e as demais legislações relacionadas a resíduos sólidos. A legislação que trata especificamente do RCD é muito recente, aparecendo somente em 2002. Antes disso, o tratamento do RCD estava submetido à legislação que trata dos resíduos sólidos em geral.

Essa legislação se concentra principalmente no Estado de São Paulo e em sua capital, apesar de existir também em outras capitais do país, como Rio de Janeiro, Belo Horizonte e Curitiba. Isso se deve ao fato que o Município de São Paulo, assim como o Estado, possuem a maior geração de resíduos sólidos do país. Dessa forma, essa legislação serve como base para outros pontos do país. Serão analisadas, em específico, as legislações do Município de São Paulo (1987, 2002a, 2002b, 2005), do Estado de São Paulo (1999, 2003a, 2003b, 2003c), (SMA 2002), (CETESB, 2002) e a legislação federal (CONAMA, 2002, 2003, 2004).

A Resolução 307 do CONAMA (2002) (complementada pela Resolução CONAMA 348, de 2004, que inclui os resíduos de amianto como Classe D), serve como base para a definição da legislação de todo país, apresenta como grande mudança o fato que, pela primeira vez, o gerador é o responsável pelo resíduo por ele gerado. Dessa forma, a preocupação da indústria da Construção Civil volta-se não apenas para contratar um caçambeiro, e sim para todo o desenvolvimento de uma logística na geração, gestão e transporte desses resíduos até seu destino final. Além disso, existe a divisão do resíduo em quatro Classes diferentes, dependendo de suas características. Essas Classes são:

Classe A: são os resíduos reutilizáveis ou recicláveis como agregados, tais como:

a) De construção, demolição, reformas e reparos de pavimentação e de outras obras de infra-estrutura, inclusive solos provenientes de terraplanagem;

b) De construção, demolição, reformas e reparos de edificações: componentes cerâmicos (tijolos, blocos, telhas, placas de revestimento, etc.), argamassa e concreto; 
c) De processo de fabricação e/ou demolição de peças pré-moldadas em concreto (blocos, tubos, meios-fios, etc.) produzidas nos canteiros de obras;

Classe B: são os resíduos recicláveis para outras destinações, tais como: plásticos, papel/papelão, metais, vidros, madeiras e outros;

Classe C: são os resíduos para os quais não foram desenvolvidas tecnologias ou aplicações economicamente viáveis que permitam a sua reciclagem/recuperação, tais como os produtos oriundos do gesso;

Classe D: são os resíduos perigosos oriundos do processo de construção, tais como: tintas, solventes, óleos e outros, ou aqueles contaminados oriundos de demolições, reformas e reparos de clínicas radiológicas, instalações industriais e outros, bem como telhas e demais objetos e materiais que contenham amianto ou outros produtos nocivos à saúde.

Conforme a Resolução 307, todo município deve criar um Programa Municipal de Gerenciamento de Resíduos da Construção Civil, que deve conter o cadastramento de áreas públicas ou privadas aptas para receber o resíduo conforme sua classificação, o estabelecimento de processos de licenciamento dessas áreas, os critérios de cadastramento de transportadores e ações de orientação, fiscalização e controle dos agentes envolvidos. Enquanto isso, o grande gerador, a partir de janeiro de 2005, deve apresentar um Projeto de Gerenciamento de Resíduos da Construção Civil, que estabeleça os procedimentos a serem tomados para o correto manejo e destinação do resíduo gerado em seu empreendimento. Esse Projeto deverá ser apresentado juntamente ao trâmite de obtenção da licença de construção.

Uma das principais falhas dessa Resolução é que dá tratamento diferenciado a gerador de pequeno e grande porte, mas não estabelece critérios para diferenciá-los. Assim, utiliza-se a determinação do Município de São Paulo (1987), onde o pequeno gerador é aquele que gera menos de $50 \mathrm{~kg}$ de resíduo, uma quantidade ínfima perto do peso próprio dos materiais de construção. Isso leva ao não cumprimento da legislação, já que qualquer pequena reforma, feita sem nenhum auxílio técnico (e, assim, sem uma 
empresa responsável) tem potencial de gerar pelo menos uma caçamba $\left(4 \mathrm{~m}^{3}\right.$ ou aproximadamente 5 toneladas de material).

Outra crítica é que não diferencia os municípios por tamanho e/ou capacidade de aplicação da resolução. Grande quantidade de municípios não possui sequer aterro sanitário, quanto mais a capacidade de estabelecer pelo menos quatro destinos diferentes, um para cada Classe.

No Estado de São Paulo, a principal legislação é a Resolução 41 da Secretária Estadual do Meio Ambiente (SMA, 2002). Ela dispõe sobre procedimentos para licenciamento de aterros de resíduos inertes e da construção civil no Estado de São Paulo, o que regulamenta, no Estado, a criação das áreas previstas no Programa Municipal de Gerenciamento de Resíduos da Construção Civil.

No Município de São Paulo, a legislação caracteriza o conceito de pequeno gerador. Ele é o gerador que é responsável por não mais que $50 \mathrm{~kg}$ de entulho, e sua remoção é de responsabilidade da Prefeitura, conforme a Lei $n^{\circ} 10.315$ (1987) e o Decreto $n^{\circ} 46.594$ (2005). Dessa forma, qualquer obra ou reforma que gere mais que essa quantidade deve seguir a resolução CONAMA 307. Prevendo a dificuldade de um gerador informal dispor de forma correta seu resíduo, a Prefeitura, através do Decreto 42.217 (2002a), regulamenta a Lei n’ 10.315 ("Lei do Lixo”, de 1987), no que se refere ao uso de áreas destinadas ao transbordo e triagem de resíduos de construção civil e resíduos volumosos (ATTs), criando os Pontos de Entrega de pequenos volumes, que serão gerenciados pelo poder público.

Segue, no Anexo I, como complemento, um resumo da legislação mais relevante, com comentários.

\subsubsection{Enfoque Logístico da Legislação}

A mudança da legislação, principalmente com a Resolução CONAMA 307, traz impacto direto na logística do RCD nos dois subsistemas apresentados no Capítulo 1. 
No subsistema interno à obra, cria-se a necessidade de segregar o resíduo gerado nas quatro Classes apresentadas pela Resolução CONAMA 307 (2002). Tem-se aí o desafio logístico de segregação, armazenagem e transporte interno desse resíduo, que antes era tratado de uma forma mais simples, sem a necessidade de segregação. Como citado no Capítulo 1, é nessa fase que a Construtora pode atuar de forma mais independente, assim essas alternativas serão detalhadas mais à frente, no Capítulo 3.

No subsistema externo à obra, a mudança de responsabilidade (do poder público para a Construtora) da deposição final do RCD traz um novo desafio logístico às Construtoras. Com a nova legislação, a Construtora responde legalmente pelo controle da cadeia logística de transporte externo e deposição final e/ou reciclagem do RCD. Dessa forma, torna-se obrigatória a necessidade de garantir que o resíduo seja transportado e depositado de forma legal, bem como providenciar a documentação necessária para comprovar isso perante uma fiscalização.

Porém, a Resolução CONAMA 307 não trata esse problema de forma específica, no tocante a incentivar a expansão dos fornecedores, públicos ou privados, dessa cadeia. Apesar de exigir que todo município crie um Programa Municipal de Gerenciamento de Resíduos da Construção Civil, ela não diferencia o porte de cada um deles. Com isso, exige-se dos municípios de pequeno porte uma estrutura que acaba se tornando sofisticada demais para os baixos volumes de RCD gerados. Conforme a Resolução CONAMA, municípios que não possuem sequer aterro sanitário são obrigados, desde janeiro de 2005, a manter os custos de uma estrutura logística que garanta diferentes formas de deposição para cada Classe de resíduo. Além disso, devido aos custos e à baixa demanda, é muito difícil incentivar a iniciativa privada a criar empresas de transporte e de reciclagem ou deposição do resíduo.

O incentivo à formação dessa rede de locais de disposição final pode ser observada na Resolução 41 da Secretária Estadual do Meio Ambiente (SMA, 2002), de São Paulo. Esse incentivo se dá na forma da distinção dos aterros de acordo com sua capacidade, diminuindo assim a burocracia para regulamentar aterros de pequeno porte. Além disso, permite que terrenos de até $1.000 \mathrm{~m}^{2}$ sejam nivelados com resíduos Classe A sem necessidade de autorização, bem como permite a utilização de cavas de mineração 
como aterro. Com isso, contribuí-se para a disseminação de pontos de deposição, facilitando a logística do RCD.

Já na legislação do município de São Paulo, o Decreto 42.217 (2002a) também possui uma boa iniciativa na determinação dos locais dos Pontos de Entrega e ATTs, determinando que eles devem estar localizados preferencialmente em locais já degradados pelo depósito de entulho. Com o cumprimento disso, é possível legalizar áreas que foram, de forma informal, escolhidas pela facilidade logística de acesso. Por outro lado, o município de São Paulo determina, através da Lei n 10.315 (1987), que é considerado pequeno gerador aquele que gera no máximo $50 \mathrm{~kg}$ diários de resíduos. Isso foi confirmado através do Decreto 46.594 (2005), onde se exige que estabelecimentos que gerem acima de $50 \mathrm{~kg}$ diários de resíduo devem se cadastrar na AMLURB (Autoridade Municipal de Limpeza Urbana). Para analisar esse coeficiente de geração, vale citar Pinto (1999), que informa que uma caçamba de resíduo (muito comumente distribuídas pelas grandes cidades) tem uma carga típica entre 3,6 e 6 toneladas. Esse baixo coeficiente de geração acaba incluindo obras de porte muito pequeno no escopo da legislação, que muitas vezes não possuem sequer acompanhamento técnico e que se vêem obrigadas a participar da cadeia logística sem possuir conhecimentos nem recursos para fazer isso de forma legal.

\subsection{PERDAS E PRODUTIVIDADE NA CONSTRUÇÃO CIVIL}

O objetivo de um Plano de Gestão de Resíduos deve ser, em primeiro lugar, reduzir a quantidade de resíduo gerado, com o objetivo de minimizar a quantidade que deve ser gerenciada. Assim, é importante levantar quais conceitos estão relacionados às perdas de material na Construção Civil. Da mesma forma, é importante que este Plano não tenha impacto (ou tenha impacto irrisório) na produtividade da execução dos trabalhos. O impacto na produtividade afeta diretamente os custos da obras e, se existir de forma relevante, torna-se um obstáculo para a aplicação do Plano. 


\subsubsection{Perdas na Construção Civil}

O conceito de perdas é normalmente associado ao desperdício de materiais. Porém, deve-se entender como perda a ineficiência causada pelo uso de equipamentos, materiais, mão-de-obra e capital em quantidades superiores àquelas necessárias (BOGADO, 1998).

Em qualquer processo, devido à variabilidade natural, é inevitável que ocorra um determinado volume de perdas. A fração das perdas que excede a este limite mínimo característico da tecnologia é considerada desperdício (JOHN, 2000a).

As perdas podem ser classificadas de acordo com a possibilidade de serem controladas e com sua natureza. Os critérios de perdas constam nos trabalhos de Shingo (1981) e Skoyles (1987), conforme compilados abaixo:

1 - Perdas segundo seu controle:

- Perdas inevitáveis: são aquelas onde o investimento para sua redução ultrapassa a economia gerada por ela, correspondendo assim a uma perda aceitável;

- Perdas evitáveis: são conseqüência de um processo de baixa qualidade, onde os recursos são empregados de forma inadequada.

2 - Perdas segundo sua natureza:

- Perdas por superprodução: são aquelas que ocorrem quando é produzida uma quantidade maior que a necessária; por exemplo: produzir gesso em quantidade acima da consumida em um dia de trabalho;

- Perdas por substituição: ocorre quando é utilizado um material de desempenho superior ao necessário, como um concreto com resistência maior que a especificada em projeto; 
- Perdas no transporte: refletem-se em perdas de tempo, exemplo: grande distância entre o estoque e a grua; ou então perdas de materiais, por manuseio incorreto ou pelo uso de equipamentos de transporte inadequados;

- Perdas no procedimento: têm origem nas falhas de procedimento ou no não cumprimento destes. Além disso, estão relacionadas à falta de treinamento da mão-de-obra, ineficiência dos métodos construtivos ou, então, à falta de detalhamento dos projetos. Como exemplo pode-se citar a quebra da alvenaria para passagem dos sistemas prediais;

- Perdas de estoque: ocorrem quando existe estoque excessivo, causado pela programação inadequada da entrega dos materiais ou erros no quantitativo físico da obra, gerando falta de local adequado para estoque. Também pode ocorrer quando o estoque é feito em condições inadequadas como, por exemplo, armazenagem de areia diretamente sobre o solo;

- Perdas pela elaboração de produtos defeituosos: essas perdas estão relacionadas com falta de treinamento, materiais inadequados, problemas de planejamento ou falta de controle do processo construtivo. Causam redução do desempenho final ou retrabalho, como falhas em impermeabilizações ou erros em prumadas;

- Outras: englobam perdas por roubo, vandalismo, acidentes e outros eventos extraordinários.

Outra característica que colabora com as perdas é o atraso da construção civil em relação à indústria de transformação. Farah (1992) apud Scardoelli (1995) indicam algumas dessas características, sendo elas:

- Processo produtivo com predomínio de trabalho manual, baixo grau de mecanização e uso intensivo de mão-de-obra;

- Alta incidência de patologias e necessidade de refazer os serviços; 
- Ocorrência significativa de perdas ao longo da construção.

Assim, percebe-se que o Plano de Gestão de Resíduos deve abordar o desperdício, através da redução das perdas de materiais, de melhor planejamento na fase de projeto, de novos métodos construtivos e procedimentos sólidos de controle e avaliação da aplicação do Plano. Pinto (1999) define uma "taxa de geração de resíduos de construção" da ordem de 150 quilos por metro quadrado construído.

\subsubsection{Produtividade na Construção Civil}

A produtividade pode ser definida como uma relação entre as entradas (materiais e componentes ou mão-de-obra) necessárias para o estabelecimento do processo e as saídas (quantidade de serviço executada) do mesmo (SOUZA, 1997). Assim, pode-se distinguir a produtividade no uso de materiais da produtividade no uso da mão-de-obra.

A produtividade no uso dos materiais está intimamente ligada às perdas descritas no item anterior. Para avaliar a produtividade, pode-se determinar indicadores como o de consumo, que expressa a quantidade de material utilizado por unidade de serviço, ou ainda de perdas, comparando o consumo real versus o teoricamente necessário.

Esses indicadores podem ser utilizados para comparação relativa entre situações de obras diferentes, para comparação entre diferentes tecnologias e até mesmo para corrigir indicadores de orçamentos.

A mão-de-obra possui também grande importância na produtividade da construção civil. De acordo com Souza (2000), a mão-de-obra é o recurso mais precioso participante da execução de obras de construção civil, não somente porque representa alta porcentagem do custo mas, principalmente, em função de se estar lidando com seres humanos.

Para quantificar a produtividade da mão-de-obra, Souza (1997) sugere a utilização de um índice parcial, denominado Razão Unitária de Produção (RUP), que relaciona os homens-hora utilizados (entradas) com a quantidade de serviço executada (saídas). Considerando o Modelo dos Fatores, de Thomas (1987), a produtividade diária variaria 
apenas em função do aprendizado, se todos os outros fatores continuassem constantes durante o trabalho. Porém, a produtividade real varia devido a fatores, como o tipo de serviço sendo executado, as condições de como está sendo executado esse serviço e a metodologia aplicada, isto é, como está sendo executado o serviço.

Ao mesmo tempo, pode-se desmembrar o tempo do operário em três tipos. O primeiro é o improdutivo, que trata do tempo parado e em trânsito do funcionário. O segundo é o auxiliar, que compreende medições e nivelamentos, transporte de materiais e preparação dos mesmos. O último é o tempo produtivo, onde o operário está de fato produzindo o serviço que deve ser executado. Serpell (1993) apud Bogado (1998) afirma que os valores de referência internacional apontam para uma divisão de $33 \%$ para cada um desses três tipos.

Com isso, o Plano de Gestão de Resíduos deve prezar, como citado no item anterior, pela produtividade no uso dos materiais e atentar para que, nos novos procedimentos da mão-de-obra, a Razão Unitária de Produção não seja afetada, fazendo que esses procedimentos se encaixem como atividade auxiliar, reduzindo o tempo improdutivo e sem afetar o tempo produtivo.

\subsection{PRÁTICAS ANTERIORES}

A construção civil sempre foi acusada, muitas vezes com razão, de ter uma enorme taxa de desperdício de material. Na década de 70 e início de 80, havia uma grande demanda imobiliária, estimulada em grande parte pelos recursos disponibilizados pelo BNH (Banco Nacional da Habitação) (OLIVEIRA, 1998). Dessa forma, o mercado imobiliário aceitava empreendimentos executados com baixo investimento tecnológico e métodos construtivos arcaicos, que ainda assim geravam alto lucro. A concorrência era relativamente pequena e foi nessa fase que diversas construtoras surgiram, ao mesmo tempo em que várias pessoas tinham, como diversificação de investimento, aplicações na construção civil de pequeno porte.

A característica mercadológica começou a mudar na década de 90 , quando o mercado iniciou seu desaquecimento (BRASIL, 2004). Imediatamente, o lucro das construtoras 
caiu de próximo a $100 \%$ para $30 \%$ na média. Para manter-se na ativa, as construtoras precisaram diminuir o preço final de seus empreendimentos e o lucro vinha agora também da especulação financeira propiciada pela situação econômica da época. No fim dessa década, com o surgimento de diversas construtoras, houve a necessidade da diminuição dos custos construtivos para manter uma taxa de lucro minimamente atrativa nessa parte. Iniciaram-se, então, os processos de terceirização para redução de pessoal, qualificação da mão-de-obra própria remanescente, mudança dos processos construtivos e a introdução de novas tecnologias.

Essas mudanças foram consolidadas na década de 90 (BOAS, 1996), quando se tornaram condições obrigatórias para a existência de uma construtora. O mercado estava saturado com novas empresas e novos imóveis, ocorreu uma diminuição no poder aquisitivo da classe média, a estabilização econômica determinou o fim dos altos ganhos com especulação financeira e, assim, os investimentos começaram a ser feitos no processo produtivo. Com isso, as taxas de desperdício baixaram para em torno de $2 \%$. Esse processo de redução de custos construtivos foi muito eficiente durante esse período. Como existia imenso desperdício de recursos físicos e humanos, o investimento para uma grande redução inicial era comparativamente baixo.

Porém, no fim dos anos 90 e início da primeira década do século XXI, a redução "fácil e barata" desses desperdícios havia se esgotado. Seria necessário um alto investimento em tecnologia e pessoal para uma melhora mínima nos indicadores de desperdício de material. Ao mesmo tempo, o principal lucro das construtoras não estava mais relacionado ao processo construtivo (CBIC, 2005). A classe média havia se estabilizado financeiramente (apesar da queda no poder aquisitivo) e a economia apresentou as condições mínimas para que um investimento com pagamento a longo prazo pudesse ser planejado. Dessa forma, o lucro das construtoras voltou-se para a área financeira, porém agora através da aplicação de juros no pagamento a longo prazo de seus empreendimentos.

Agora, com a responsabilidade sobre o resíduo gerado, as construtoras novamente deverão investir em seus processos construtivos. Se o objetivo dessa nova legislação tem o cunho ambiental de diminuir a deposição final de resíduos e aumentar seu reuso e reciclagem, a primeira ação deve ser a redução da quantidade a ser tratada. 


\subsection{EXPERIÊNCIAS INTERNACIONAIS}

Como mencionado na Introdução deste Capítulo, as experiências internacionais no tratamento de resíduos de construção e demolição possuem em geral um alto nível de sofisticação. Essa sofisticação é alcançada devido ao acesso mais barato à tecnologia, bem como a necessidade de compensar altos custos de material e também de mão-deobra, que em compensação possui uma formação melhor que a de seus colegas brasileiros, estando assim mais apta a utilizar essa tecnologia. Além disso, existem limitações legais à deposição do RCD, bem como altas taxas para fazer essa deposição.

Um exemplo do uso da tecnologia é dado por Chen (2002), em Hong Kong. Devido à alta taxa de RCD nos resíduos sólidos de Hong Kong, ele estudou o assunto, inferindo que um método eficaz de reduzir os resíduos é a utilização de métodos construtivos mais modernos, como peças de concreto pré-moldadas, concreto de alta resistência, formas metálicas e utilização de gesso acartonado de forma bastante disseminada.

Além disso, ele propõe um programa de incentivo através de gratificação financeira de equipes pela redução do resíduo gerado. Para controlar o consumo de material, ele sugere o uso de etiquetação do material com utilização de códigos de barra para controlar o estoque do almoxarifado e quantificar quanto material cada equipe solicitou. Impressiona o fato do sistema de código de barras estar em uso em Hong Kong, para gerenciamento de material e ferramentas, desde 1987.

Também em Hong Kong, Poon (2001) sugere a separação do RCD em duas Classes: Inertes e Não inertes. Essa separação é motivada principalmente pela legislação local, de 1998 , que proíbe que resíduos que contenham mais de $20 \%$ de RCD inerte sejam depositados em aterros. Além disso, em seu trabalho ele afirma que em breve será cobrada uma taxa US\$7,00 por tonelada de material depositado.

Outro estudo de Poon (1997) sugere essa mesma separação, porém tratando somente o resíduo de demolição. Porém, ele estima que os custos com equipamentos (como separadores magnéticos para itens ferrosos e trituradores) podem aumentar os custos da demolição em até $20 \%$. Deve-se considerar, ainda, que esta tecnologia é pouco difundida no Brasil, em comparação com Hong Kong. 
Outra iniciativa vem de Klang (2003), que trata do gerenciamento de resíduos de demolição, com o objetivo de diminuir seu impacto ambiental através da reciclagem ou reuso desses resíduos. Esse trabalho foi desenvolvido em conjunto na Noruega e Suécia, e tinha também como objetivo reinserir no mercado de trabalho profissionais da Construção Civil que estavam há muito tempo desempregados. O foco do trabalho era o reuso de tijolos inteiros e peças metálicas e cerâmicas dos banheiros.

O resultado desse trabalho é interessante, pois possui um alto valor social (uma experiência que muitas vezes é seguida no Brasil, através de cooperativas de reciclagem). Além disso, o uso de tecnologia, com um equipamento que limpa os tijolos, não impacta muito nos custos. O maior impacto de custo está no preço da hora-homem. Provavelmente, se fosse implementado no Brasil, essa razão entre custos se inverteria, isto é, o custo com equipamentos suplantaria o custo com mão-de-obra.

Um exemplo de emprego de tecnologia na separação de resíduos de RCD é dado por Huang (2002), em Taiwan. Pelo fato de ser uma ilha, portanto com pouco espaço para aterros, e de ser freqüentemente atingida por terremotos, a preocupação de Taiwan com o RCD é bem justificada. O método de separação consiste em um processo com vários equipamentos, passando pelas fases de peneiramento grosso, médio e fino; separação magnética; classificação por ar comprimido (para retirada de papéis e plásticos) e finalmente uma separação manual, para retirada de madeira, materiais nãoferrosos e outros. O trabalho demonstra que o tempo de retorno do investimento para o equipamento, pessoal e manutenção, é de pelo menos três anos.

Porém, esse retorno não corresponde à realidade brasileira, já que ele considera o custo de deposição do resíduo não segregado variando entre US $\$ 20,00$ e US $\$ 28,00$ por tonelada, bem como existe um subsídio do governo de Taiwan de US\$10,00 por tonelada de resíduo tratado que deixa de ir direto para o aterro. 


\subsection{ENFOQUE AO PROBLEMA}

O problema do Resíduo de Construção Civil deve ser tratado considerando todos os aspectos de um empreendimento, não somente focar o tratamento ao resíduo que está sendo gerado. Dessa forma, o tratamento do problema deve ser feito observando alguns conceitos que auxiliam a investigação e tratamento do problema com um todo. São eles o Enfoque Sistêmico, a Logística Reversa, a Logística "Verde" e as Técnicas de Pesquisa Operacional.

\subsubsection{Enfoque Sistêmico}

Uma metodologia de trabalho para a abordagem de problemas é o enfoque sistêmico (Churchman, 1968; Gualda, 1995). O enfoque a ser dado ao problema pode ser caracterizado em quatro abordagens distintas:

1- Científico: determinação do problema, divisão em subsistemas passíveis de mensuração, modelagem, proposições e teste das alternativas;

2- Eficientista: mantém o foco na eficiência do sistema, isto é, considera a busca pelo maior lucro ou menor prejuízo;

3- Humanista: tem sua preocupação na qualidade e bem estar, assim possui parâmetros mais subjetivos, relacionados ao que é melhor para as pessoas;

4- Antiplanejador: acredita que, em face ao problema, ocorrerá sua solução sem a necessidade de intervenção.

$\mathrm{Na}$ metodologia científica, devem ser consideradas cinco etapas básicas para determinar como solucionar o problema:

1- Os objetivos e suas medidas de efetividade, ou seja, qual o objetivo do problema e como mensurar se ele foi atingido; 
2- O ambiente do sistema, isto é, o ambiente onde o sistema está inserido, que influencia o problema, porém, dentro do sistema proposto, não existe controle sobre esse ambiente;

3- Os recursos do sistema e suas restrições, disponíveis para solucionar o problema;

4- Os componentes do sistema, que são divisões do sistema para facilitar sua análise, onde são identificadas suas atividades, finalidade e medidas de desempenho;

5- A administração do sistema, responsável pela solução do problema e por manter as propostas de solução factíveis.

Ao mesmo tempo, existe como complemento (De Neufville, 1971) uma segunda definição de análise sistêmica, onde são levantados também cinco passos para a resolução do problema:

1- Definição de objetivos;

2- Formulação das medidas de efetividade;

3- Geração de alternativas;

4- Avaliação das alternativas;

5- Seleção da alternativa que melhor atende o problema.

Assim, como em Gualda (1995), se complementa a definição inicial com a análise e escolha das diferentes alternativas. Dessa forma, tem-se o modelo que será empregado no desenvolvimento deste trabalho. 


\subsubsection{Logística Reversa e Logística "Verde"}

A logística reversa pode ser definida como o processo de planejar, implementar e controlar de modo eficiente e eficaz o fluxo de matéria-prima, embalagens, estoque, bens acabados e suas respectivas informações do ponto de consumo para o ponto de origem, com o objetivo de agregar valor a esse material ou então dispor dele da forma correta (ROGERS, 1998). Outra forma de definir a Logística Reversa é através da comparação com Logística Direta. Rogers e Tibben-Lembke (1998) apud Biazzi (2002), fazem essa definição. Assim, se Logística é:

"O processo de planejamento, implementação e controle eficiente (inclusive em custos) de matérias-primas, materiais em processo, produtos acabados e informações relacionadas do ponto de origem para o ponto de consumo para atender às necessidades do cliente." Então:

"Logística Reversa é o processo de planejamento, implementação e controle eficiente (inclusive em custos) de matérias-primas, materiais em processo, produtos acabados e informações relacionadas do ponto de consumo para o ponto de origem para atender às necessidades de recuperação de valor e/ou obter o descarte correto/controlado."

A logística reversa é uma modalidade nova, principalmente no Brasil. Nos Estados Unidos e Europa ela já é implementada em alguns setores e, como exemplo, na Alemanha os fornecedores são obrigados por lei a recolher de volta suas embalagens.

No caso do Brasil, em particular na construção civil, essa modalidade não é aplicada, salvo raras exceções. Dessa forma, a definição de Logística Reversa apresentada acima merece uma variação, acrescentando que a função de agregar valor (no caso reciclagem) ou a deposição final depende, muitas vezes, do consumidor.

Vale aqui discutir, então, a diferença de Logística Reversa para a Logística "Verde", isto é, aquela onde existe a preocupação ambiental na cadeia logística. Como dito anteriormente, a Logística reversa se refere a agregar valor a produtos gerados no final de um processo, ao invés de simplesmente sua deposição. A Logística "Verde" se refere a entender e minimizar os impactos ambientais na cadeia, como consumo de 
energia, quantidade e tratamento do resíduo gerado ou modos de transporte (Corson, 1990).

Várias atividades de Logística "Verde" podem ser classificadas como Logística Reversa. A figura abaixo, de Biazzi (2002), esclarece o posicionamento de algumas atividades comuns entre Logística Reversa e "Verde":

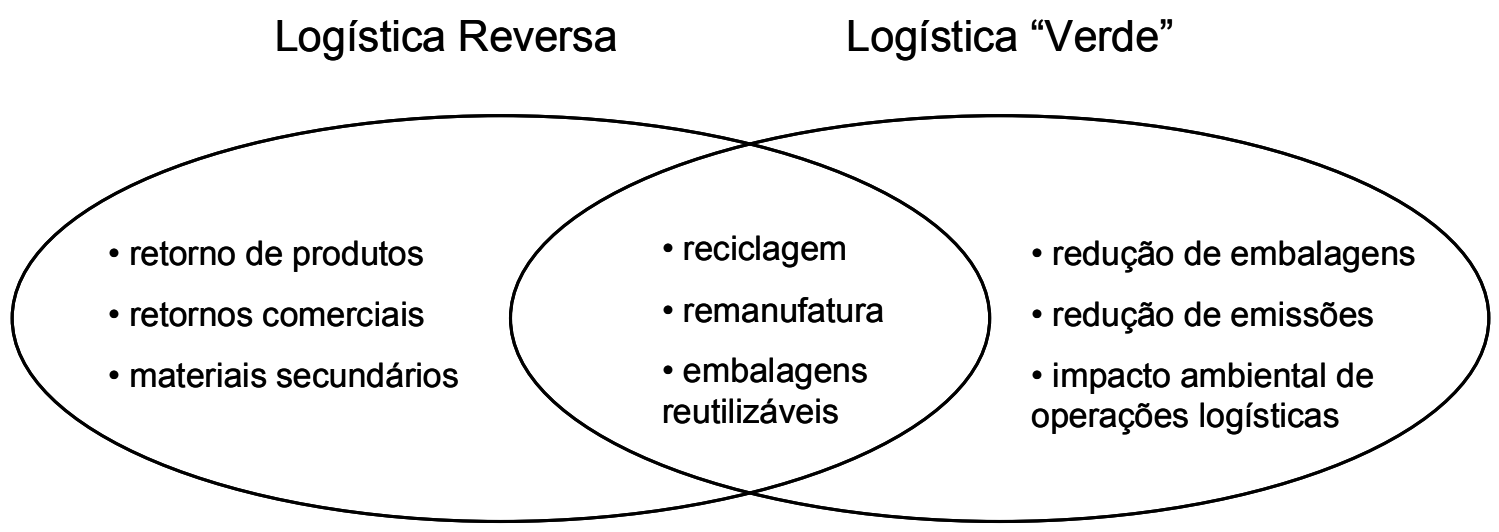

Figura 2.1. Comparação entre Logística Reversa e Logística "Verde".

Um exemplo que se aplica ao nosso caso é o do aço, onde seu resíduo é encaminhado ao próprio fornecedor (Logística Reversa), que assim se responsabiliza em reciclá-lo, diminuindo o consumo de recursos naturais e energia (Logística "Verde").

Ambas as categorias são de extrema importância no caso do RCD. Isso porque, hoje em dia, alguns fornecedores já aceitam os resíduos ou embalagens de volta. Aqueles que não o fazem, como será demonstrado posteriormente, estão em processo de negociação junto às construtoras, através do Sinduscon, para agirem observando os dois conceitos: diminuir o impacto ambiental dos resíduos provenientes de seus produtos e, junto a isso, aceitarem de volta esse resíduo para incorporá-lo novamente em sua cadeia produtiva, ou enviá-lo para reciclagem ou deposição final. Ballou (1993) pondera que alguns fatores se apresentam como entrave para o avanço da Logística Reversa, como a estrutura de intermediários pouco desenvolvida e ineficiente e os fretes mais caros devido aos volumes menores. 


\subsubsection{Técnicas de Pesquisa Operacional}

A Pesquisa Operacional trata da utilização de um modelo com o objetivo de solucionar um problema real. Essa modelagem pode ser feita de acordo com diversas técnicas disponíveis que, conforme Gualda (1995), podem ser divididas em duas classes:

- Modelos Determinísticos, como entre outras as Teorias de Programação Linear, de Programação Inteira, da Teoria dos Grafos e de Fluxo em Redes;

- Modelos Estocásticos, como a Teoria das Filas, dos Jogos, da Análise de Decisão e da Simulação.

Os Modelos Determinísticos podem ser divididos em dois tipos: estáticos e dinâmicos (BIANCHI, 2000). Os modelos estáticos são aqueles onde os parâmetros de entrada são conhecidos e obtidos a partir de uma base de dados de um período fixo. Como são baseados em uma dada posição de tempo, podem se tornar uma solução sub-ótima no futuro (BALLOU, 1993). Já os modelos dinâmicos assumem que certos parâmetros variam com o tempo, porém essa variação se dá sempre de forma determinística (OWEN, 1998). Dessa forma, com o conhecimento de todos os parâmetros, pode-se desenvolver o modelo para obter a solução ótima.

Já no caso de Modelos Estocásticos, considera-se que se tem um conhecimento limitado dos parâmetros do modelo. Neles, o objetivo é determinar uma solução com boa performance sob um número possível de parâmetros. Para analisar esse problema, podese adotar duas abordagens: modelos probabilísticos e planejamento de cenários (VALLIM, 2004). Os modelos probabilísticos consideram de forma explícita a distribuição probabilística das variáveis aleatórias, enquanto os modelos de planejamento de cenário consideram a geração de um grupo de possíveis valores futuros para as variáveis (OWEN, 1998).

A análise de um problema onde se objetiva alcançar uma solução ótima, nem sempre pode ser feita através de um Modelo Determinístico, que garante esse ótimo. Isso ocorre porque nem sempre é possível determinar um algorítmo que reflita de forma satisfatória a realidade e que, dessa forma, possa satisfazer a necessidade de fornecer um resultado ótimo como solução. 
Quando isso ocorre, utiliza-se o desenvolvimento de uma heurística, que é o seqüenciamento da evolução de fatos do problema que, em princípio, levam a solução deste problema. Com a utilização desse recurso ao invés do algorítmo, não se pode garantir que se obtenha a solução ótima. Porém, se esse seqüenciamento for representado de forma fiel ao que ocorre no problema real, pode-se obter uma solução próxima do ótimo, que atende a necessidade de resolução do caso.

\subsubsection{Simulação e a Utilização do Programa Arena 7.0}

A simulação é uma das técnicas de pesquisa operacional, que tem como objetivo utilizar métodos científicos para solucionar problemas complexos de decisão (SCHRIBER, 1991).

A simulação teve sua origem como extensão do Método de Monte Carlo, proposto por von Neumann e Ulam, no Laboratório de Los Alamos, durante a Segunda Guerra Mundial (SALIBY, 1989; GORDON, 1978). Inicialmente, esse Método era utilizado na avaliação de integrais múltiplas, usando-se amostragem aleatória para o estudo da difusão de nêutrons. No início da década de 50, com o advento dos primeiros computadores, a idéia do Método de Monte Carlo foi extendida para a solução de problemas probabilísticos em geral. Assim, viu-se que era possível simular um processo e estimar seus principais parâmetros de operação.

A modelagem por simulação permite uma descrição detalhada do sistema considerando um grande número de variáveis, possibilitando assim um tratamento mais realista de seu comportamento, mesmo que ele apresente características complexas. Como desvantagem, a simulação não oferece a solução ótima, porém um modelo que tenha uma boa descrição do problema real pode ser mais vantajoso que um modelo de otimização que necessite de simplificações devido à sua complexidade matemática (VALLIM, 2004).

Schriber (1991) indica quais são as principais vantagens e desvantagens da simulação. Algumas vantagens são: 
- Realismo: os modelos podem ser realistas, no sentido de capturar as verdadeiras características do sistema sendo modelado;

- Sistemas não existentes: o sistema a ser analisado não precisa, necessariamente, existir para ser simulado;

- Compressão do tempo: o tempo pode ser comprimido nos modelos de simulação. O equivalente a dias, semanas e meses de operação do sistema real pode ser simulado em segundos, minutos ou horas em um computador.

Algumas desvantagens da simulação são:

- Especificidade de resultados: os resultados de uma simulação só se aplicam para aquela simulação em específico, não podendo ser generalizados;

- Tratamento de dados: na simulação, o tratamento de dados é feito através das médias obtidas nos dados de entrada. Dessa forma, ela não capta variações pontuais que ocorrem na realidade;

- Falta de otimização: a simulação não é uma técnica de otimização. As alternativas consideradas são aquelas que de fato estão sendo investigadas; assim, a simulação não gera novas soluções, apenas avalia aquelas que foram propostas;

- Longos períodos de estudo: um estudo de simulação deve ser iniciado bem antes da necessidade de seu resultado, já que é necessário um grande período de tempo para acumular dados e construir, verificar e validar modelos.

Ainda segundo Schriber (1991), a simulação oferece grandes vantagens, porém suas desvantagens não podem ser ignoradas. Ainda assim, essas desvantagens estão diminuindo de importância com o tempo, graças ao desenvolvimento das ferramentas de simulação, metodologias, performance computacional e a diminuição do custo com computadores. 
A simulação por computador é usada em diversas áreas, como a meteorologia ou mesmo substituindo modelos reais, como os estudos aerodinâmicos feitos com maquetes. Isso é possível, pois se alimenta o computador com características do sistema real, criando um ambiente virtual onde ele efetua os cálculos necessários para a interação do objeto de estudo com esse ambiente.

Uma das áreas da simulação por computador é a simulação de processos, e é nessa categoria que o Arena 7.0 se encaixa. Por processos deve-se entender uma situação onde elementos estáticos, formando um ambiente bem definido com suas regras e propriedades, interagem com elementos dinâmicos, que fluem dentro deste ambiente (Paragon, 1998).

\subsection{CONCLUSÃO DO CAPÍTULO}

O problema da Gestão dos Resíduos de Construção Civil, na bibliografia, possui sua abordagem principalmente para o tratamento por parte dos governos ou então sua caracterização como resíduo. Da mesma forma, experiências internacionais são de difícil aplicação, devido aos seus altos custos e diferenças na legislação.

Cabe, dessa forma, focar o estudo na área legal, para entender como esse problema deve ser abordado devido às restrições, determinações e encaminhamentos tratados na legislação brasileira e estudar o impacto logístico dessa legislação. Da mesma forma, é necessário entender os itens que influenciam as perdas e a produtividade da Construção.

Para abordar o problema, se mostra interessante o enfoque sistêmico, com o objetivo de analisar o problema de forma estruturada, utilizando também conceitos de Logística Reversa e Logística "Verde".

A simulação poderá der utilizada como técnica de avaliação e busca da resolução do problema, através do programa Arena 7.0. Com isso, pode-se analisar diferentes resultados dependendo da abordagem a ser dada ao problema. 


\section{CAPÍTULO 3. METODOLOGIA ADOTADA}

\subsection{INTRODUÇÃO}

A metodologia será desenvolvida para a aplicação ao problema de gestão de resíduos gerados na construção de um edifício e, conforme demonstrado na Revisão Bibliográfica, será baseada na aplicação do enfoque sistêmico e modelagem através de simulação. Além disso, toda a Metodologia deve ser compatível com a legislação vigente, em especial a Resolução CONAMA 307.

Assim, a Metodologia proposta será calcada em dois passos: a utilização do enfoque sistêmico e a geração e avaliação de alternativas para a caracterização do problema; e modelagem através de simulação.

\subsection{ENFOQUE SISTÊMICO}

A caracterização do problema será feita através da utilização do Enfoque Sistêmico presente na Revisão Bibliográfica, conforme descrito por Churchman (1968) e Gualda (1995).

A aplicação do Enfoque Sistêmico na Gestão de Resíduos de Construção Civil deve ser feita para determinar, de forma objetiva, todos os componentes do problema, através da metodologia científica. Com isso, a explanação da caracterização a ser seguida segue em detalhe abaixo.

\subsubsection{Objetivo e Medidas de Efetividade}

O objetivo proposto é executar um Plano de Gestão de Resíduos de acordo com a nova legislação. Para considerar esse Plano funcional, dentro desse objetivo, devemos analisar quatro aspectos principais, que servem como medida da efetividade do Plano de Gestão de Resíduos: 
a) Redução do resíduo gerado, reduzindo tanto a massa a ser tratada como o consumo de materiais. Essa redução será avaliada considerando três diferentes parâmetros: volume de resíduo gerado por metro quadrado de construção $\left(\mathrm{m}^{3} / \mathrm{m}^{2}\right)$; massa de resíduo gerado por metro quadrado de construção $\left(\mathrm{kg} / \mathrm{m}^{2}\right)$; e massa total de resíduo em comparação com massa total da construção (\%);

b) Do resíduo gerado anteriormente, reduzir a quantidade encaminhada para deposição final, reduzindo assim o impacto ao meio ambiente. Isso é feito através da limpeza e conseqüente segregação do resíduo para reciclagem, cuja avaliação será feita pela porcentagem do volume de resíduo enviado para reciclagem em relação ao volume total de resíduo;

c) Rastreabilidade, através de documentação, que o envio de todo o resíduo para reciclagem ou deposição final foi feito cumprindo a legislação;

d) Redução do custo de tratamento do resíduo como um todo, mostrando a viabilidade financeira do Plano.

Tanto o controle de geração como o de destinação foram feitos através de documentos que garantem a rastreabilidade das informações. $O$ modelo do documento utilizado está no Anexo II.

Percebe-se que, dentro das medidas de efetividade, existem diferentes abordagens do Enfoque Sistêmico além do científico, representado pelo item ' $c$ '. Temos a complementação do enfoque eficientista nos itens ' $a$ ' e 'd' e do humanista, relacionado ao meio ambiente, também nos itens ' $a$ ' e ' $b$ '.

Isso é essencial para atingir o objetivo, pois para o mercado em geral, e para o da construção civil em particular, o critério eficientista, relacionado a custos financeiros, é de extrema importância, senão o mais importante. Apesar do objetivo ser o enquadramento à legislação, é notório que a fiscalização governamental possui diversas falhas, tanto de procedimento, como de abrangência e conduta, que levam o mercado a ponderar se o cumprimento à legislação, caso ocorra aumento de custos, 
deve ser de fato mantido. O aspecto humanista, relacionado ao meio ambiente, inserese na preocupação cada vez maior de esgotamento de áreas de deposição e de fontes de matéria-prima.

\subsubsection{Ambiente e Recursos do Problema}

O ambiente do problema, isto é, a parte relacionada ao problema que não se pode controlar, é a área governamental. A mudança no ambiente, com a criação da Resolução CONAMA 307, foi a força motriz que gerou, em primeira instância, o próprio problema. Da mesma forma, o governo municipal, em seu papel de ambiente, é responsável por garantir áreas para deposição final das diferentes Classes de resíduo, fato esse ainda não cumprido para os resíduos de Classes C e D. Dessa forma, tomase como premissa do sistema que o ambiente não alterará a legislação e cumprirá seu papel, como determinado na resolução CONAMA 307.

O recurso do sistema são os operários da edificação, isto é, a hora-homem disponível para o trabalho de classificação e transporte do resíduo. É também recurso do problema a disponibilidade de área no térreo para armazenagem dos resíduos e sua eventual triagem.

\subsubsection{Componentes do Problema e sua Administração}

Os componentes do problema estão associados, basicamente, a três funções: a redução da geração de resíduos, a segregação e transporte interno do resíduo e seu transporte externo para reciclagem ou deposição final. Assim, dividi-se o sistema em três subsistemas: o de redução, um interno à obra e outro externo.

O subsistema de redução de resíduo tem como atividade desenvolver, em projeto, execução ou junto a fornecedores, formas de diminuir a geração de resíduo, com a finalidade de existir uma menor massa a ser tratada nas etapas posteriores. Sua medida de efetividade será, como veremos na aplicação feita a um caso, a geração de resíduos, em $\mathrm{m}^{3} / \mathrm{m}^{2}$ e em $\mathrm{kg} / \mathrm{m}^{2}$ de construção. 
O subsistema interno tem como atividade limpar a área de trabalho, segregar o resíduo em suas diferentes Classes e transportá-lo até a área de espera para retirada, com a finalidade de preparar o resíduo para retirada do empreendimento, de forma que ele possa ser encaminhado corretamente no próximo subsistema. Sua medida de efetividade é a correta limpeza e segregação do resíduo.

O subsistema externo tem como atividade o transporte dos resíduos para reciclagem ou deposição final, cumprindo a legislação. Sua medida de efetividade é que toda a documentação referente a essa entrega esteja registrada e arquivada, mantendo a rastreabilidade das informações e garantindo que sua tarefa foi executada de acordo.

A administração do sistema, responsável pela execução do Plano de Gestão de Resíduos, pode ser dividida em três níveis: o estratégico, representado pela Diretoria da Empresa; o tático, representado pela engenharia, onde o Plano foi desenvolvido e aprimorado; e o operacional, onde figuram os operários envolvidos na construção do empreendimento e que foram responsáveis pela implementação do Plano de Gestão de Resíduos.

\subsection{GERAÇÃO E AVALIAÇÃO DE ALTERNATIVAS}

Como complemento ao Enfoque Sistêmico, a geração e avaliação de alternativas (De Neufville, 1971; Gualda, 1995) será utilizada para tratar das diferentes alternativas de abordagem possíveis ao problema.

Cada fase da obra pode necessitar de soluções diferentes, devido ao tipo de resíduo gerado. Dessa forma, foram propostas algumas soluções, que estão localizadas em pontos diversos do espectro total das soluções possíveis. As alternativas se complementam, também, a partir dos dois subsistemas do processo:

Subsistema interno: separação do resíduo: 
1- Separação de todas as Classes feita nos andares da obra, através de quatro recipientes distintos, sendo que quando cheios ou eles seriam descarregados em dutos de resíduo específicos, que descarregariam o material em caçambas no térreo, ou então transportados pelo elevador de carga até o térreo;

2- Separação total no térreo, sendo que os produtos desceriam misturados em um único duto até uma caçamba no térreo, e aí separados.

3- Retirada de todo o resíduo, sem segregação, para uma Área de Transbordo e Triagem (ATT).

Subsistema externo: transporte do resíduo separado:

1- Transporte direto para deposição final utilizando caminhões da construtora;

2- Transporte de todo o material através de contrato com empresa especializada;

3- Contato com cooperativas de reciclagem que retirariam o material da obra, e contato com fabricantes dos produtos de Classe $D$, que se responsabilizam pela retirada e destinação de seus recipientes. O restante do material é encaminhado por uma empresa especializada, ou pela própria construtora.

Avaliação das Alternativas:

Para a separação do material:

Alternativa 1: Separação de cada Classe nos andares, o que resultaria em maior organização no térreo, já que não seria executado nenhum serviço fora dos andares. Porém, todos os funcionários devem ser treinados para reconhecer e separar cada categoria de resíduo, e executariam uma tarefa que não é seu trabalho especializado. Além disso, devem ser instalados quatro dutos diferentes, o que aumenta o custo da movimentação vertical do resíduo, ou então, ocupar periodicamente o elevador de carga com a descida desse material. 
Alternativa 2: Separação total no térreo, sem que os funcionários necessitem separar o resíduo nos andares, o que tem como vantagem não ser necessário introduzir uma nova cultura em todos os funcionários. A desvantagem é que todo o resíduo viria misturado, sendo mais difícil de identificá-lo, além do aumento do trabalho realizado no térreo.

Alternativa 3: A remoção de todo o resíduo para uma Área de Transbordo e Triagem, sem segregação, tem como principal vantagem a continuação do modelo de tratamento existente, não sendo necessário introduzir a cultura da segregação junto aos operários. Isso, porém, anula os benefícios da segregação para a Construtora. Quando segregado, o resíduo reciclável pode ser retirado direto da obra por uma empresa de reciclagem, não havendo assim o custo de remoção para a Construtora.

Para o transporte do resíduo separado:

Alternativa 1: Transporte com caminhões da própria construtora, que tem como vantagem à possibilidade de evitar acúmulos de resíduo na obra, liberando espaço no canteiro, e a facilidade de documentação da deposição. Porém, é necessário que a construtora tenha recursos materiais e pessoais dedicados a esse serviço.

Alternativa 2: Transporte feito através de uma empresa especializada, que tem como vantagem que, através de um contrato pré-estabelecido, pode-se programar as retiradas, evitando um grande acúmulo de resíduo na obra, porém maior que na alternativa 1. Além disso, não é necessário mobilizar ativos da construtora para efetuar o transporte. Porém, fica mais difícil manter comprovação do destino do resíduo.

Alternativa 3: Retirada do resíduo reciclável por associações de reciclagem, ou pelas indústrias; tem-se a vantagem da documentação ser entregue diretamente na obra. Um exemplo são associações de catadores de papel, ferros-velhos, siderúrgicas que retiram pontas de aço e empresas de tintas e solventes, que se responsabilizam por recipientes de seus produtos. Além disso, existe a vantagem da diminuição do volume a ser transportado com ônus para a construtora, o que barateia o transporte, tanto no caso da utilização de transporte próprio ou contratado. A desvantagem está na necessidade de separar o resíduo reciclável em suas diversas categorias, e a falta de regularidade na 
retirada desses materiais, que devem ter um acúmulo mínimo para retirada, o que implica um maior espaço ocupado dentro do canteiro.

Além das alternativas apresentadas, existe ainda a opção da retirada de todo o resíduo, sem segregação, para uma Área de Transbordo e Triagem (ATT).

Dentre as alternativas apresentadas

Entre as alternativas apresentadas, não existe uma combinação imediata entre a melhor solução para cada subsistema. Isso porque a melhor combinação de alternativas dependerá muito dos aspectos individuais de cada obra e de cada construtora, havendo itens mais relevantes que custos financeiros, como a viabilidade de espaço no canteiro, por exemplo. Além disso, pode existir a dificuldade da conscientização dos operários, principalmente se na obra existirem muitas subempreiteiras com trabalhos pontuais e pouco prazo de permanência na obra.

\subsection{CARACTERIZAÇÃO DO PROBLEMA}

Com isso, pode-se aprofundar o modelo apresentado no Capítulo 1 , sendo que a metodologia para o tratamento do RCD passa a possuir três grandes abordagens: a redução do RCD gerado; as diferentes formas de tratar esse resíduo dentro da obra; e como destiná-lo para reuso, reciclagem ou deposição final.

\subsubsection{Redução do Resíduo}

Como citado anteriormente, a redução da geração de resíduos não ocorre mais através da solução de um problema localizado que proporciona, se solucionado, grandes economias. Assim, existe a necessidade de atuar de forma global no empreendimento, desde seu projeto até sua execução final, passando pelos fornecedores e serviços terceirizados contratados.

Preocupações simples na fase de projeto, como modulação de alvenaria e acabamentos, reaproveitamento de fôrmas e caminhamento de sistemas prediais 
podem reduzir bastante a geração de resíduos. Da mesma forma, através da conscientização dos fornecedores e equipes de trabalho, aliada a novos métodos construtivos, existe a possibilidade de reduzir ainda mais a geração de resíduos inerente à atividade.

A redução da quantidade de resíduo gerado assume três principais objetivos. Inicialmente, é a redução de custo do material, já que com essa diminuição necessariamente diminui a quantidade de material utilizada para executar a mesma tarefa. Quanto menos resíduo for gerado, menos trabalho será necessário para gerenciar e tratar esse passivo, o que leva ao critério relacionado ao ganho ambiental, pois diminui a quantidade de resíduo a ser depositado no meio ambiente.

\subsubsection{Tratamento Dentro da Obra}

A separação do resíduo na obra, nas diferentes Classes, é um processo dinâmico com o tempo. Dependendo da fase da construção, a geração de resíduo difere muito no que se refere às porcentagens de cada tipo de Classe.

Além da separação em Classe, ocorre a separação de materiais pertencentes à mesma Classe, principalmente aqueles pertencentes à Classe B. Um exemplo é que, por uma questão de reciclagem, plásticos, papéis, metais e madeiras são separados entre si, mesmo pertencendo a mesma Classe. A separação do resíduo pode ocorrer em dois momentos: durante a geração, em cada andar; ou no térreo, antes do transporte para fora da obra.

Na separação nos andares, são necessários recipientes específicos para cada tipo de resíduo, localizados em todos os andares. Esses recipientes são de pequeno volume, e devem ser esvaziados pelos funcionários da limpeza, que os verificariam durante o dia. O resíduo seria então transportado ao térreo, onde é colocado em caçambas ou baias para esperar sua retirada. Para esse procedimento, é necessária a conscientização de todos os funcionários que atuam na obra, já que todos devem saber identificar o resíduo que geram, e acondicioná-lo no recipiente apropriado. 
Na separação no térreo, todo o resíduo seria transportado misturado até uma área de triagem, onde um ou mais funcionários fariam a separação. Esse processo tem como vantagem a não necessidade do treinamento e fiscalização de todos os funcionários, porém é claro que a triagem de um grande volume é muito mais complexa.

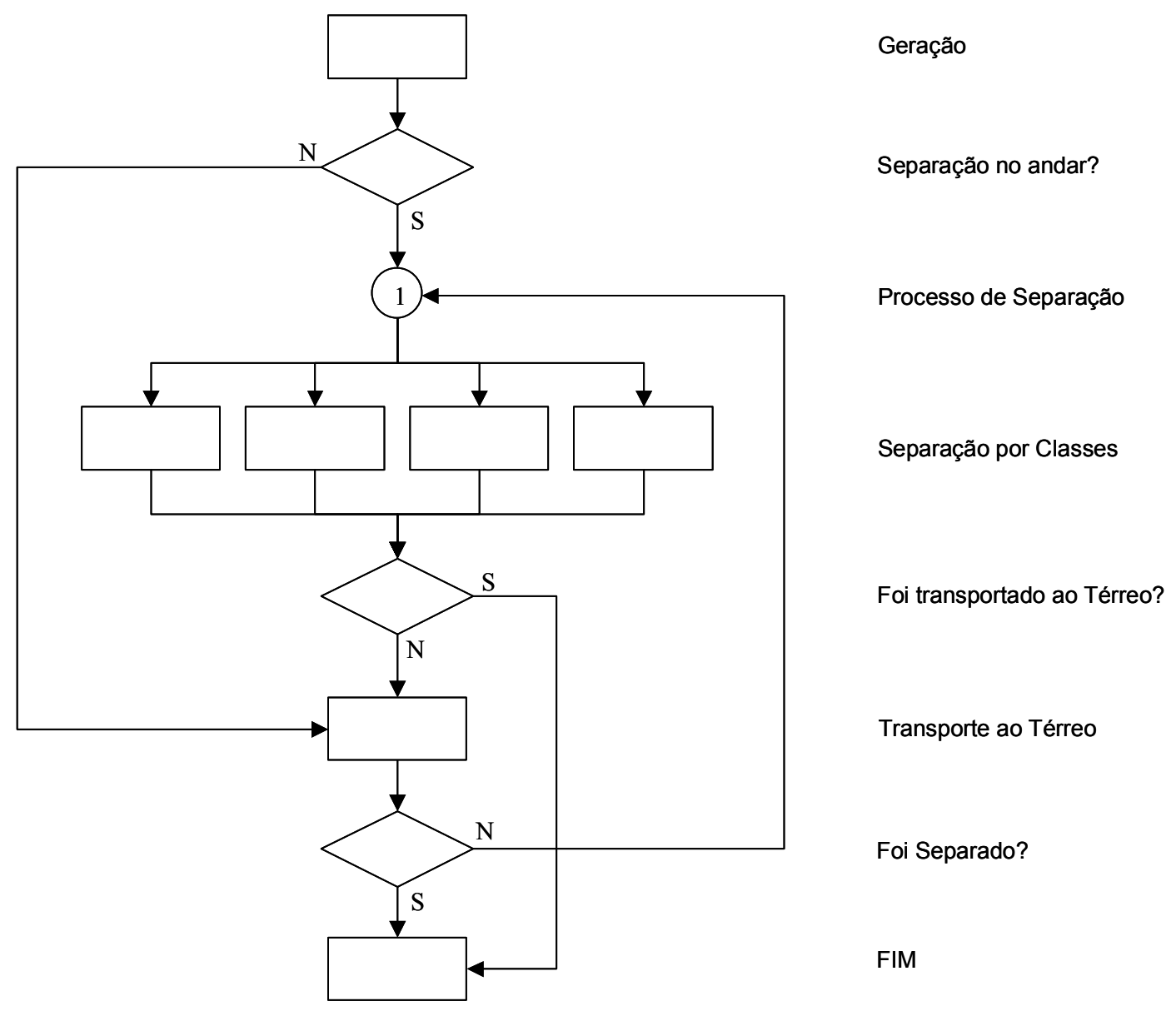

Figura 3.1. Possibilidades de separação do resíduo.

Independente de qual alternativa seja escolhida, é imprescindível que seja controlada a qualidade da separação, já que caso haja muita contaminação entre as Classes, nenhum receptor desse material irá aceitá-lo.

Existe, ainda, a possibilidade de não separar o resíduo dentro da obra. Ao invés disso, pode-se optar por levar toda a massa, misturada, até uma área de triagem externa a obra. O Decreto $n^{\circ} 42.217$ do Município de São Paulo (2002) considera essa opção utilizando as ATT's (Área de Transbordo e Triagem de Resíduos da Construção Civil) 
que são estabelecimentos privados ou então os Pontos de Entrega Público, porém esse somente para pequenos volumes.

\subsubsection{Destinação Final do Resíduo}

O transporte e deposição final do resíduo representam um ponto crítico do sistema já que o resíduo, a princípio, não segue necessariamente direto da obra para o depósito final ou reciclagem. Assim, existe a possibilidade da empresa que retira o resíduo da obra o levar a um pátio onde outra empresa, com maior capacidade de transporte ou tratamento, o leva até o depósito final. Outra situação que ocorre é que os materiais reciclados são comprados da empresa que retira o resíduo, separados e revendidos a diferentes indústrias de reciclagem. Dessa forma, fica clara a dificuldade de manter a documentação sobre o destino final de todo o resíduo. O esquema a seguir demonstra o ciclo de transporte e indica o fluxo reverso de documentação que deve ocorrer:

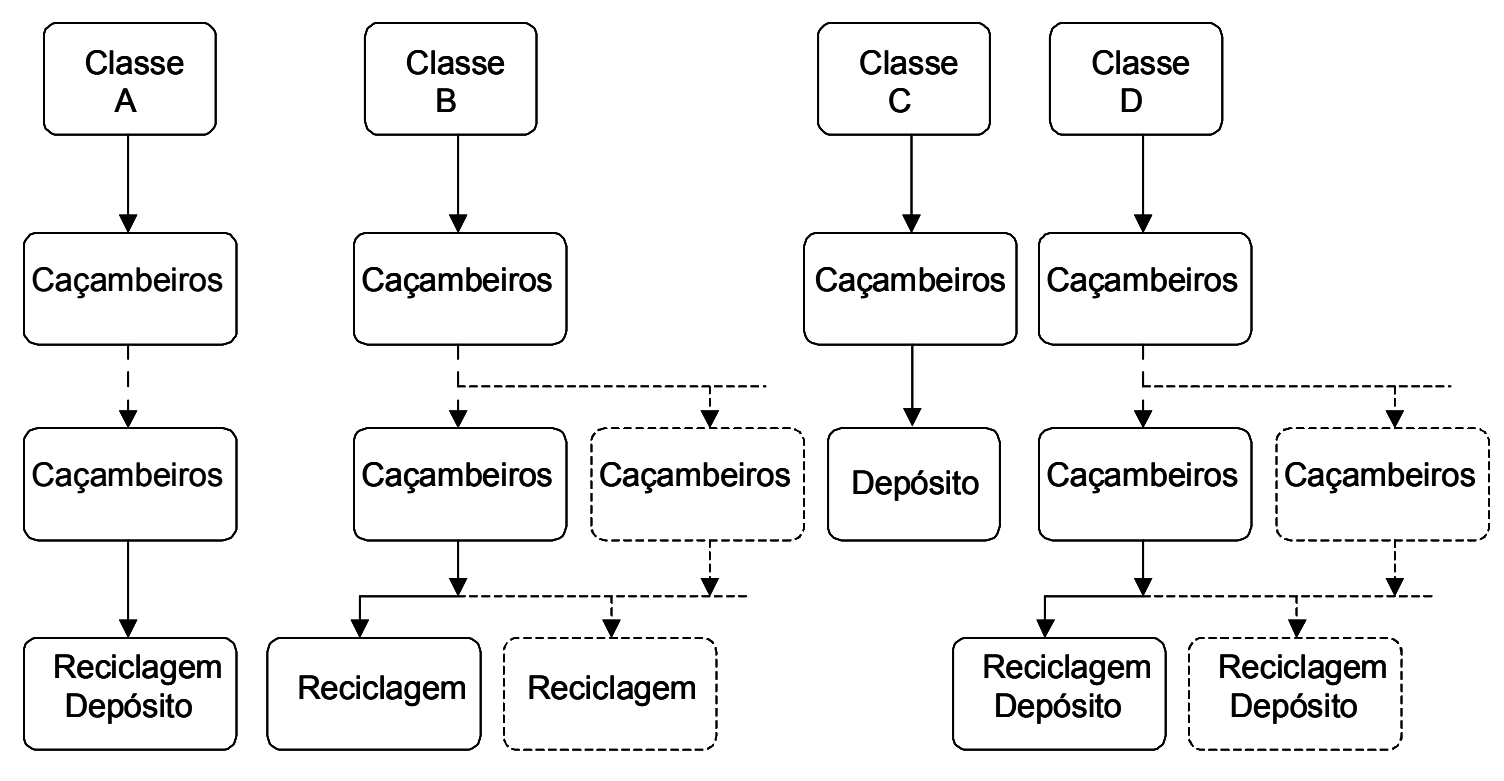

Figura 3.2. Ciclo de transporte do resíduo.

Devido a essa complexidade, a empresa deve tentar encurtar o máximo possível essa cadeia, isto é, tentar que o transporte seja feito diretamente da obra para o depósito 
final ou reciclagem. Com isso, é encurtado o caminho da documentação, fator essencial caso ocorra fiscalização da obra.

Uma questão ainda em aberto é a localização de destinos para as diferentes Classes. De acordo com a Resolução CONAMA 307 (2002), cada município deve preparar um Plano Diretor de Gestão de Resíduos, que deve determinar onde o resíduo será processado pelo município e onde será permitido o depósito final. O município de São Paulo não tem esse plano ainda definido, porém as discussões estão ocorrendo com a participação de diversas organizações além da Prefeitura, como faculdades, sindicatos e institutos.

Outro aspecto é que, qualquer que seja a destinação do resíduo, ela deverá ser feita respeitando Normas Técnicas da ABNT. O que ocorre é que muitas delas estão sendo revistas enquanto outras, como a destinação de gesso e seus subprodutos, estão sendo inteiramente elaboradas, já que não havia anteriormente nenhuma norma específica para esses subprodutos.

\subsection{MODELO DE SIMULAÇÃO}

O modelo de Simulação, estruturado com o auxílio do programa Arena 7.0, permitirá a análise do Plano de Gestão de Resíduos aplicado em edifícios. Com esse modelo, será possível simular tanto a redução do resíduo gerado quanto sua segregação.

O modelo foi dividido em diversos blocos, com o objetivo de representar o diferente encaminhamento feito pelo resíduo. Assim, ele foi concebido da seguinte forma:

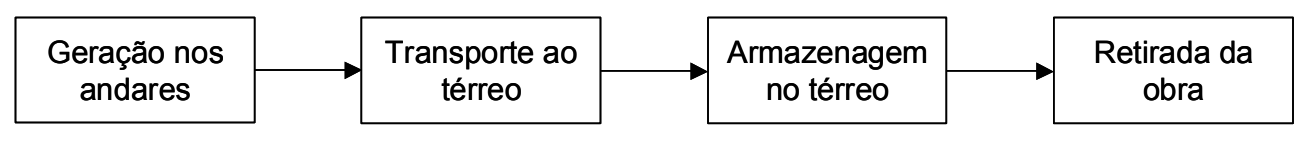

Figura 3.3. Blocos de encaminhamento dos resíduos no modelo. 
Além desses blocos de encaminhamento de resíduo, foram criados blocos de apoio, que tem como objetivo servir de suporte a essa lógica, ou então visualizar e exportar informações do modelo. Esses blocos são:

- Sistema de contadores: é o bloco responsável por marcar em qual dia de obra a simulação está, bem como verificar se os elementos de armazenagem no térreo estão com sua ocupação máxima;

- Gravadores de dados read write: exportam dados selecionados para serem processados no Excel. Nesse caso os dados são: a geração total de cada resíduo por dia, o andar em que a grua atinge sua capacidade máxima, a quantidade de caçambas e o uso do piso para os resíduos de madeira, mineral e terra;

- Visualizadores intermediários e finais: é o bloco onde diversos dados do modelo são apresentados durante sua execução, com o objetivo de possibilitar o acompanhamento dos resultados.

Nesse modelo serão utilizadas simplificações, que têm como objetivo torná-lo menos complexo, porém sem influenciar o resultado final desse modelo. A primeira simplificação está relacionada à geração do resíduo no tempo. Será inicialmente considerado um período de tempo onde ocorre a preparação do terreno e execução das fundações. Após isso, um pavimento será iniciado com intervalo constante, sendo que todos os pavimentos terão a mesma duração de obra e gerarão resíduos de forma idêntica dentro desse período. Devido ao faseamento da obra, considerando a preparação e fundação, o resíduo de terra será considerado separadamente dos minerais, mesmo ambos pertencendo à Classe A. Isso será feito, porque a terra é gerada somente nesses serviços, não havendo geração na execução dos pavimentos.

Assim, para determinar a taxa de geração de resíduo, utilizou-se o seguinte raciocínio:

1 - o total de resíduo gerado na obra (em litros) nos dois primeiros meses de obra, divido pelos dias da obra, para obter a média de geração por dia na preparação do terreno e fundação; 
2 - esse valor será dividido por 8 horas, para obter a geração em litros por hora trabalhada do dia;

3 - Para o início dos pavimentos, será determinado o total de resíduos (desconsiderando os dois primeiros meses) e esse valor será dividido pelo número de andares do edifício. Com isso, temos a geração em litros de resíduo por andar;

4 - esse valor será dividido pelos dias trabalhados em cada andar e, em seguida, por 8 horas, para obtermos a geração em litros por hora trabalhada por andar;

5 - para incluir variações que possam ocorrer nesta média, será considerado que ela obedece a uma distribuição exponencial.

\subsection{CONCLUSÃO DO CAPÍTULO}

Nesse Capítulo observamos como o enfoque sistêmico, explanado na Revisão Bibliográfica, deve ser utilizado no Plano de Gestão de Resíduos da Construção Civil. Com a definição do objetivo e suas medidas de efetividade até a análise de alternativas, pudemos prosseguir para a Colocação do Problema.

Nela, é detalhado como o resíduo poderá ser tratado em um edifício. A escolha por edifícios foi feita pois eles representam a grande maioria das construções de médio e grande porte executadas, porém essa metodologia pode ser adaptada a outros empreendimentos, como obras de arte, por exemplo.

Foi também explanado como os modelos de simulação serão utilizados. Da mesma forma como anteriormente, o modelo foi concebido para simular a geração de resíduos em edifícios (mais precisamente o edifício da aplicação em um caso, que será tratado no próximo Capítulo). Esse modelo teve como objetivo avaliar o resultado de diferentes implementações do Plano de Gestão de Resíduo. 


\section{CAPÍTULO 4. APLICAÇÃO EM UM CASO}

\subsection{INTRODUÇÃO}

A aplicação do Plano de Gestão de Resíduos foi realizada em edifícios de uma mesma Construtora. Essa aplicação foi baseada em um edifício residencial multifamiliar de alto padrão, que possui $5.453 \mathrm{~m}^{2}$ distribuídos em 20 pavimentos, construído no período de junho de 2003 a janeiro de 2005, que será identificado como Edifício Piloto. Como comparativo, foi escolhido um edifício com as mesmas características do anterior, com $4.307 \mathrm{~m}^{2}$ distribuídos em 16 pavimentos, construído pela mesma empresa e utilizando as mesmas tecnologias de construção, na mesma região de São Paulo, no período de outubro de 2001 a agosto de 2003, que será tratado como Edifício Controle. No Edifício Controle não foi aplicado nenhum plano para a gestão dos resíduos gerados na obra, somente o encaminhamento de todo o resíduo, através de caçambas, para deposição final.

A influência no canteiro é resultado de diferentes esforços em diversos aspectos da obra, iniciando com alterações no projeto, inovações no método construtivo, a implementação de um Plano de gestão de resíduos, procedimentos que distribuem responsabilidades para diferentes departamentos da construtora, treinamento e conscientização dos funcionários envolvidos em todas as etapas da obra e o controle de adequação dos procedimentos.

As decisões organizacionais de planejamento são tradicionalmente classificadas em três níveis de abordagem. Isso é feito para tratar de forma diferenciada os propósitos, o horizonte de análise, as informações agregadas, os níveis hierárquicos e os riscos envolvidos no problema. Esses três níveis são:

- Estratégico: trata dos objetivos da organização e as políticas que governam a aquisição, uso e distribuição dos recursos a serem empregados na obtenção desse objetivo. As decisões têm um horizonte longo, de mais de um ano, assim pode-se ter dados mais imprecisos ou incompletos (Shapiro, 2001); 
- Tático: o planejamento tático traduz os objetivos e planos estratégicos mais amplos em objetivos e planos específicos. Assim ele focaliza as principais ações a serem executadas para realizar sua parte do planejamento estratégico (Pellon, 2004);

- Operacional: são as decisões de curto prazo, cujo horizonte é de semanas, dias e até horas. O nível de detalhamento é máximo, focando em tarefas rotineiras, com a necessidade de ter dados muito precisos e de trabalhar freqüentemente com itens individuais (Franco, 2005)

\subsection{NÍVEL ESTRATÉGICO}

Do ponto de vista estratégico, relacionado à diretoria da empresa, o primeiro passo foi a exposição do problema, suas implicações e os diferentes resultados, tangíveis e intangíveis, relacionados com a solução desse problema.

Por mais óbvio que possa parecer, essa exposição é necessária pois estrategicamente a empresa pode decidir simplesmente não aplicar a Gestão de Resíduos. Isso pode ocorrer caso seja do entendimento da diretoria que, através de uma análise de risco, a empresa está exposta a um risco mínimo e dessa forma não há necessidade, pelo menos no momento, de tomar qualquer iniciativa.

De fato, essa análise foi feita pela empresa. Isso porque a proposta de utilizar o Plano de Gestão de Resíduos foi feita no fim de 2002, antes de haver a imposição legal, que começou dia 01 de janeiro de 2005.

A decisão de iniciar a Gestão de Resíduos antes da obrigação legal foi tomada devido à exposição de alguns pontos:

O processo de Gestão de Resíduos, que seria obrigatório em um espaço de pouco mais de dois anos, representava uma situação nova no mercado, que necessitaria da quebra de paradigmas em diversas, senão todas, fases de um empreendimento. Devido a isso, a diretoria da Construtora considerou uma vantagem competitiva iniciar o processo 
antes de sua obrigatoriedade, pois quando esse dia chegasse, todos os procedimentos e processos já teriam sido trabalhados e estariam funcionando. Dessa forma, a empresa estaria pronta para uma fiscalização desde o primeiro dia de aplicação da Resolução CONAMA.

Além desse resultado óbvio, outra implicação está relacionada ao aprimoramento da cultura da empresa no aspecto sócio ambiental. Com o Plano, seria difundido em toda a hierarquia da empresa conceitos de educação ambiental relacionados a desperdício e reciclagem. Esses conceitos são facilmente extrapolados para o dia-a-dia dos funcionários fora de seu trabalho, contribuindo para aplicação desses conceitos em todos os ambientes nos quais essas pessoas interagem. Essa capacitação, de forma mais direta, está relacionada ao próprio funcionário da construção em seu aperfeiçoamento profissional pois, se naquele momento o Plano de Gestão de Resíduos era uma opção, a partir de janeiro de 2005 ele se tornaria obrigatório, e o profissional não capacitado terá dificuldade de se recolocar no mercado.

Somado a isso, existe o ganho de imagem da própria empresa. Em um mercado cada vez mais competitivo, e com a preocupação ambiental cada vez maior na sociedade, esse Plano apresenta um fator de marketing que pode ser um diferencial mercadológico da empresa, em relação a seus concorrentes que não aplicam o Plano.

Um fator crucial para a implantação do Plano, que será tratado em detalhe mais à frente, foi a formação pelo Sinduscon SP (Sindicato da Indústria da Construção Civil do Estado de São Paulo), através de seu Comitê de Meio-Ambiente, Segurança e Produtividade (COMASP), do primeiro Grupo de Trabalho sobre Resíduos de Construção Civil (GT Resíduos) que com a participação de onze construtoras e duas consultorias especializadas, propôs um modelo de gestão que foi aplicado, principalmente, na parte operacional desta aplicação.

\subsection{NÍVEL TÁTICO}

O nível tático, representado pela Engenharia da empresa, teve o papel de viabilizar os conceitos do Plano de Gestão de Resíduos, no que se trata de seus três pontos: 
redução da quantidade de resíduos gerados, separação e destinação desse resíduo gerado. Nos dois últimos pontos, foi utilizado o procedimento proposto pelas consultorias através do Sinduscon, com pequenas modificações para se adaptar a particularidades do empreendimento. O foco da redução da quantidade de resíduo gerado foi dado a dois principais aspectos: o projeto e os métodos construtivos.

Além disso, a engenharia foi responsável pela negociação com diversos fornecedores sobre a responsabilidade deles em relação a embalagens e desperdícios no transporte, que serão comentados durante as explicações a seguir.

\subsubsection{Alterações no Projeto}

As alterações envolveram diversos itens de projeto, como estrutura, instalações elétricas e hidráulicas, alvenaria e acabamentos.

$\mathrm{Na}$ execução da estrutura, o principal item gerador de resíduos são as fôrmas. Para minimizar esse efeito, foi determinado como objetivo o menor número de recortes possível na estrutura. Dessa forma, vigas foram suprimidas através do aumento de espessura das lajes e reposicionamento dos pilares. Com isso, além da diminuição dos resíduos de corte de fôrmas, obtém-se o ganho de uma estrutura mais limpa, com uma menor quantidade de pontos que possam interferir em outras etapas da construção.

As instalações elétricas e hidráulicas possuem um alto índice de geração de resíduos de alvenaria, já que essa é recortada para o embutimento de eletrodutos e tubulações. Essa geração é maior na instalação horizontal desses itens que na vertical, já que na posição vertical os eletrodutos, que são flexíveis, podem ser posicionados no interior dos blocos. Dessa forma, o objetivo desses projetos era o de minimizar ao máximo qualquer instalação de eletrodutos e tubulações na posição horizontal, dando preferência à movimentação através da parte de baixo da laje superior, onde existirá forro e as interferências de vigas foram minimizadas no projeto de estrutura.

O projeto de alvenaria foi executado levando-se em consideração dois aspectos: modulação e interferências de instalações hidráulicas e elétricas. No quesito 
modulação, foram feitos alguns estudos com blocos cerâmicos de diversas dimensões, com o objetivo de minimizar a necessidade de quebra de blocos para ajuste da fiada. Com isso foram escolhidos blocos de diversas dimensões, sendo que alguns deles são feitos de tal forma que possuem pontos específicos para quebra, e podem ser talhados ao meio ou a um quarto de seu comprimento sem comprometer a parte restante, que tem um aproveitamento posterior.

Mesmo com os projetos de hidráulica e elétrica minimizando a quantidade de movimentação de tubulações e eletrodutos na posição horizontal, é antieconômico que isso seja feito em $100 \%$ dos casos. Para melhor compatibilizar a relação da alvenaria com as instalações hidráulicas e elétricas, essa movimentação horizontal foi equalizada para sempre estar na mesma altura em relação ao piso. Com isso, a fiada de blocos nessa altura possui uma profundidade menor, de 14,5 cm (ao contrário dos 19,5 cm do restante), o que permite o embutimento dos canos e eletrodutos sem a necessidade de recorte da alvenaria, sendo que esse espaço depois é preenchido com argamassa.

No quesito acabamento, a Construtora entrega a cerâmica e azulejos colocados, porém sem o piso do restante do apartamento, permitindo ao comprador que escolha aquele que mais lhe agrada. Além disso, as áreas comuns do prédio já são entregues com o piso colocado. Para esses acabamentos, foi feito um estudo de paginação, de tal forma que minimize a necessidade de corte das peças, gerando dessa forma menos entulho e diminuindo a possibilidade de quebras no ajuste.

\subsubsection{Métodos Construtivos}

As alterações em métodos construtivos ocorreram em todas as etapas da construção: estrutura, alvenaria, instalações e acabamentos. O objetivo principal dessas alterações foi a diminuição da geração de resíduos, o que influi diretamente em economia dos materiais utilizados.

Na parte de estrutura, foi utilizado concreto comprado diretamente de uma concreteira. Mesmo isso não sendo uma inovação na Construtora, que há muito não fabrica seu próprio concreto, a inovação está na limpeza da betoneira. Antigamente, essa limpeza 
era feita diretamente dentro de uma caçamba, gerando entulho e diminuindo o espaço útil da mesma, já que esse concreto secava no fundo da caçamba e diminuía seu volume. Atualmente, esse concreto proveniente da limpeza é utilizado para concretar peças que não necessitam de resistência estrutural, como as floreiras do prédio. Com isso, economiza-se tanto na compra de concreto como na gestão desse resíduo. $\mathrm{Na}$ parte da ferragem utilizada, ela já vem do fornecedor cortada e dobrada, o que evita desperdícios na hora do manuseio das mesmas. Mesmo essa também não sendo uma prática nova na Construtora, é uma atitude que representa uma importante diminuição na geração de resíduos.

A gestão do método construtivo da alvenaria ocorre em duas frentes diferentes: no recebimento e na execução. No recebimento os blocos vêm acondicionados em paletes, e protegidos por filme plástico. Conforme acertado com o fornecedor, na hora do recebimento os filmes plásticos são removidos e ficam no próprio caminhão, sendo responsabilidade do fornecedor destiná-los posteriormente. Após desembalar os blocos, eles são transferidos para paletes menores, que pertencem à Construtora, e transportados diretamente para os respectivos andares onde serão utilizados. Isso é feito pela empreiteira responsável pela alvenaria, e tem como objetivo se beneficiar do acordo feito com o fornecedor e com a empreiteira que diz que, caso algum bloco seja danificado ou quebrado no transporte interno até o posicionamento final, ele é devolvido ao caminhão do fornecedor (evitando que esse entulho seja responsabilidade da Construtora), e o valor do bloco é descontado do pagamento da empreiteira (evitando que o prejuízo fique a cargo da Construtora). Com essas duas medidas, o número médio de quebras no transporte diminuiu muito, já que o fornecedor e a empreiteira tomam mais cuidado na movimentação. Além disso, os paletes dos blocos não ficam na obra, evitando o resíduo de madeira.

$\mathrm{Na}$ execução, além do fato dos blocos não serem quebrados para ajuste, existe um controle muito rigoroso no que diz respeito à precisão superficial entre as fiadas. Isso tem como objetivo diminuir a quantidade de acabamento de regularização, no caso gesso, que tem um alto índice de desperdício e é um resíduo de difícil destinação. Além disso, a argamassa utilizada é pré-fabricada e acondicionada em silos, evitando o desperdício e conseqüente geração de resíduos, além de evitar embalagens de acondicionamento dos insumos. 
As execuções das instalações hidráulicas e elétricas tinham como objetivo garantir que não houvesse recorte de alvenaria para seu posicionamento. Os eletrodutos, pelo fato de serem flexíveis, não apresentavam dificuldade nesse ponto. Porém, para possibilitar a passagem da tubulação de hidráulica, que é rígida, foi desenvolvido o seguinte sistema: O cano, tanto de PVC como de cobre, é medido no tamanho necessário e depois cortado ao meio. As duas metades são posicionadas no mesmo vão interno do bloco, e conforme as fiadas de alvenaria são executadas, a metade inferior é mantida em posição, enquanto a metade superior é elevada junto com a fiada. Quando a alvenaria chega no ponto onde a metade inferior termina, é deixada uma janela, onde serão unidas as duas metades. Quando a alvenaria chega na última fiada, e a metade superior está posicionada em seu local definitivo, ela é ligada à parte hidráulica que está posicionada no teto e, depois, ligada com a metade inferior, podendo ser feito o fechamento da janela. Com esse método, não é necessário o corte da alvenaria, porém, como desvantagem, é necessária a presença de um funcionário de hidráulica para o posicionamento correto do cano.

Na parte de acabamento, a maior preocupação está relacionada ao gesso e as tintas. O gesso será utilizado tanto no acabamento da alvenaria, sendo aplicado em forma de massa, como no forro, na forma de placas. A preocupação na instalação das placas não é grande, já que esse procedimento é relativamente industrializado e gera poucos resíduos. A maior preocupação está no gesso aplicado na alvenaria. O objetivo dessa aplicação é regularizar a superfície dos blocos para preparar a parede para receber a pintura diretamente. Para minimizar as perdas desse tipo de aplicação, que pode chegar a 30\%, a regularização na execução da alvenaria é imprescindível, porém para minimizar as perdas do material que acaba caindo no chão, foi dada uma solução extremamente simples e eficiente. $\mathrm{Na}$ área de trabalho, o funcionário posiciona uma espécie de "tapete" de borracha com espessura de aproximadamente $5 \mathrm{~mm}$. O gesso que cai nesse tapete é recolhido com uma espátula e reaproveitado imediatamente sendo que o tapete, como é de borracha, resiste ao processo de secagem do gesso que por acaso continue lá e pode ser facilmente lavado. No caso das tintas, as latas foram encaminhadas como resíduo Classe B, isto é, como metal para reciclagem. Isso foi possível pois a reciclagem se deu em alto-forno, onde o resíduo de tinta é incinerado. 


\subsubsection{Determinação de Responsabilidades}

O mais importante princípio contido na Resolução 307 é o que determina que o gerador do resíduo é responsável por sua correta destinação. Incorporando essa determinação no canteiro de obras, a Construtora compartilhou essa responsabilidade com todos os funcionários, fazendo assim que esse princípio fosse seguido desde a ponta inicial do processo.

Antigamente, os funcionários realizavam suas tarefas, geravam resíduos, e os abandonavam para a equipe de limpeza recolhê-los e enviá-los para as caçambas. Atualmente, cada funcionário que realiza uma tarefa é obrigado a recolher o resíduo gerado, separá-lo e destiná-lo a bombona correta, sendo que a equipe de limpeza fica responsável pela limpeza fina e esvaziamento das bombonas.

Esse procedimento de limpeza foi incorporado à realização da tarefa, de forma que ela não é considerada finalizada caso a limpeza não esteja de acordo. Para garantir que cada equipe seja responsável somente pela limpeza dos resíduos gerados por ela, as diferentes tarefas em uma área só têm seu início liberado após a checagem das condições de limpeza da área. Dessa forma, por exemplo, caso a equipe de alvenaria não faça a limpeza da área de forma satisfatória, isso atrasará a entrada das equipes de hidráulica e elétrica, e esse atraso será contabilizado na medida de eficiência da equipe de alvenaria, sendo que todas as equipes possuem bônus salarial por produtividade.

Com isso, existe o estímulo para que o tempo de limpeza seja incorporado no tempo total de execução, e não que ele seja uma tarefa à parte que acaba somando tempo ao processo. Dessa forma, o recurso do sistema se mantém o mesmo, não havendo restrição de hora-homem para isso. A preocupação com o aumento de tempo de trabalho em uma mesma tarefa ficou clara através de uma pesquisa feita com os funcionários.

Nessa pesquisa, foram entrevistados: o engenheiro responsável; engenheiro residente; mestres-de-obras; encarregados de elétrica, pedreiros, hidráulica, carpintaria e armadores; almoxarife e membros da equipe de limpeza. As entrevistas foram feitas no período de 21/08/03 a 10/09/03, período de início do Plano de Gestão de Resíduos. Dos questionários, pode-se chegar as seguintes conclusões: 
Inicialmente, existiu alguma resistência na hora da entrevista, sendo que os funcionários se sentiram intimidados, na tentativa de responder as perguntas de forma correta, sendo que eram instruídos, desde o início, que não existia uma resposta certa. Essa resistência apareceu em relação aos mestres, aumentando conforme a escala hierárquica foi descendo.

Esse foi o motivo principal para limitar as entrevistas nos encarregados, com exceção dos serventes de limpeza. Existia a iniciativa de entrevistar pelo menos uma pessoa de cada equipe, porém as respostas já estavam sendo distorcidas e foi decidido não continuar, pois as respostas não seriam válidas. O modelo do questionário está no Anexo III.

Nas duas perguntas que retratam as dificuldades de tratar o entulho, e o que poderia facilitar o trabalho, muitas respostas caminharam na mesma direção.

$\mathrm{Na}$ primeira resposta, todas elas se concentraram em três temas diferentes: falta de conscientização dos funcionários; falta de tempo, sendo necessário mobilizar a equipe e, conseqüentemente, atrasando a produção; necessidade de fiscalização rigorosa.

$\mathrm{Na}$ segunda questão, as respostas também estiveram focadas em dois aspectos: aumento da conscientização e maior equipe de limpeza, tanto em geral como existir um servente de limpeza inserido nas equipes.

Como principal resultado, fica a conclusão que uma atitude a ser tomada é investir na conscientização dos funcionários. Essa solução se apresenta como algo de fácil execução e atende a demanda feita pelos próprios.

Além das responsabilidades dos funcionários da obra, os Procedimentos Administrativos foram divididos entre setores da Construtora: 
Tabela 4.1. Divisão de Procedimentos na Construtora.

PROCEDIMENTO INTERNO

Quem?
\begin{tabular}{|l|}
\hline Serventes \\
Encarregado \\
Mestre \\
Eng. residente \\
Administrativo
\end{tabular}

Quem?

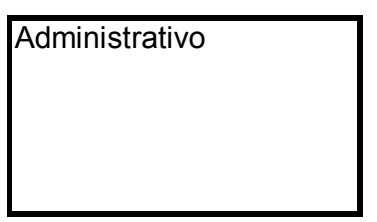

Empresa removedora retira uma das 2 vias da ficha de remoção
Quando?

Limpeza Diária

Recolhimento nos

pavimentos $3 \mathrm{x}$

por semana

\section{PROCEDIMENTO INTERNO}

Quando?

Bags - semanal

Caçambas de:

entulho - semanal

madeira - 1 dia antes

terra - semanal

FECHAMENTO DO PROCESSO

\begin{tabular}{|l|}
\hline Empresa removedora \\
volta com a via assinada \\
pela área de destino e \\
com o bag vazio
\end{tabular}

Por qual meio?

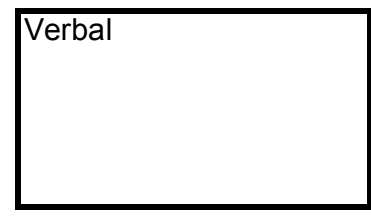

Documentos usados?

Ficha de remoção e destinação de resíduos

Cadastro de destinatário

de resíduo

Arquivo da obra

Arquivado pelo administrativo e conferido pelo

eng. residente semanal-

mente

\subsubsection{Conscientização dos Funcionários}

A Construtora tinha como uma das principais preocupações o comprometimento dos funcionários com o Plano. Essa preocupação surgiu através da comparação com outro movimento que ocorreu na construção civil, o uso de equipamentos de proteção individual (EPIs). Na época, existiu uma resistência muito grande por parte de alguns funcionários, que acreditavam que os EPIs não eram necessários e que só atrapalhavam a mobilidade e a facilidade de executar as tarefas. A preocupação estava no fato que os EPIs apresentam uma melhoria direta e imediata nas condições de trabalho do funcionário e, mesmo assim, demorou algum tempo para todos os funcionários considerarem seu uso importante. Qual seria, então, o comportamento com relação a um Planoque traz benefícios de forma indireta e a longo prazo para a qualidade de vida e trabalho? Dessa forma, a Construtora decidiu que a conscientização de todos os funcionários era uma questão fundamental para o sucesso da Gestão de Resíduos. 
Essa conscientização foi um processo composto por diversas etapas. Inicialmente foram elaboradas palestras, apresentadas pelos consultores da Obra Limpa para todos os funcionários, que abordavam o tema por diferentes aspectos. Inicialmente foi dada uma palestra ilustrando a situação atual dos resíduos, como eram tratados e, como conseqüência, os prejuízos causados. Após isso, foi apresentada uma palestra sobre a destinação dada ao resíduo segregado, reciclagem e os benefícios trazidos à sociedade com esse procedimento. A terceira palestra abordou como o Plano de Gestão de Resíduos seria implementado na obra, a importância do comprometimento de todos e os benefícios no ambiente de trabalho.

Após esse trabalho com todos os funcionários, foi feito um esforço maior para conscientizar os mestres-de-obras e encarregados. Para eles, foi passada a visão prática do Plano, abordando de forma detalhada a Resolução 307, a necessidade da Construtora se enquadrar nos procedimentos e as penalidades que poderiam existir contra a Construtora caso a Gestão de Resíduos não ocorresse de forma adequada. Além disso, foi reafirmada a maior responsabilidade desses funcionários em, primeiro, servir como exemplo e, segundo, fiscalizar e cobrar seus funcionários e também as outras equipes.

Algumas atitudes também foram tomadas pela Construtora para garantir o bom funcionamento do Plano. Além de considerar a limpeza como parte da tarefa, e contabilizá-la na performance da equipe, foi estabelecido que a receita gerada pela venda dos resíduos seria revertida para os próprios funcionários.

Foi criada, também, uma competição entre equipes que avalia a qualidade da limpeza executada por cada uma. Um quadro foi posicionado na entrada da obra, onde estavam todas as notas de cada equipe. Essas notas foram atualizadas quinzenalmente, e os membros da equipe com melhor desempenho durante a obra receberam um prêmio. $\mathrm{A}$ equipe pior colocada na quinzena recebia o título de "equiporcão", e tinha as fotos de todos os membros da equipe expostas no quadro. Isso acaba gerando uma competição não só pelo primeiro lugar, mas também para evitar a última posição, já que o título "equiporcão" vira motivo de piada entre os funcionários, e a equipe tem que agüentar isso por duas semanas. 
Além disso, foi passada a instrução aos encarregados e mestres que todos os funcionários deveriam aderir ao Plano, sem exceção. Caso eles encontrassem resistência de algum funcionário para realizar a limpeza, eles deviam primeiro notificar verbalmente a má conduta, avisar o engenheiro residente, e informar que a não-adesão não é aceitável pela Construtora. Caso isso ocorresse novamente, o funcionário seria automaticamente desligado do quadro da Construtora. Felizmente, a adesão foi completa e não houve nenhum desligamento motivado por isso.

\subsection{NÍVEL OPERACIONAL}

Neste item, iremos tratar somente da gestão dos resíduos gerados, porém os itens anteriores (determinação de responsabilidades e conscientização dos funcionários) e o próximo (controle de adequação dos procedimentos), também fizeram parte desse mesmo trabalho, sofrendo pequenas modificações para se adequarem às características individuais da Construtora.

A maior diferença entre os canteiros está no sistema de gestão de resíduos dentro da obra. Antigamente, o resíduo era removido dos andares através de um duto na fachada do prédio, que desembocava em uma caçamba. O resíduo não sofria nenhum tipo de separação e, ao encher uma caçamba, o bocal do duto era deslocado para uma caçamba vazia ao lado.

Existiram, em cada laje, quatro bombonas (recipientes plásticos) com sacos de ráfia dentro de cada um. Essas bombonas foram identificadas com cores e símbolos para caracterizá-las conforme o resíduo a ser descartado em cada uma: madeira, ferro, plástico e papel. Quando o saco de ráfia da bombona está cheio, ele é trocado por um novo, e os sacos cheios são levados ao térreo para serem esvaziados, onde existem duas baias, uma para madeira e outra para ferro, e dois bags, um para plástico e outro para papel. Os bags são grandes recipientes de lona com aproximadamente $1 \mathrm{~m}^{3}$, que ficam acomodados em um suporte metálico. Quando os bags estão cheios, eles são retirados, amarrados na ponta para fechá-lo e substituídos por um novo. Para o tratamento dos resíduos Classe $A$, foi instalado o mesmo sistema de duto na fachada, que descarrega diretamente em uma caçamba. 


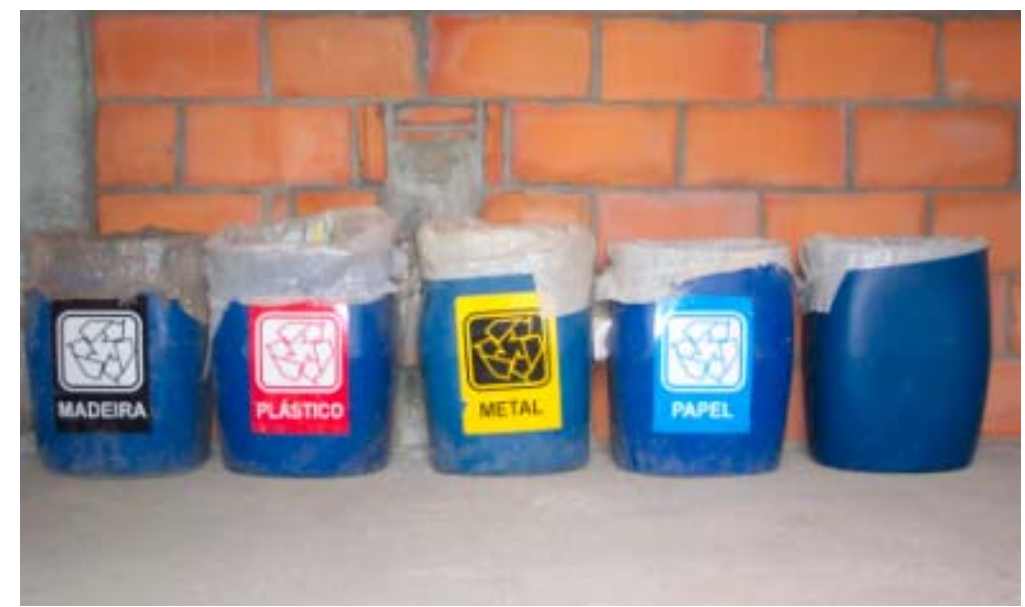

Figura 4.1. Bombonas.

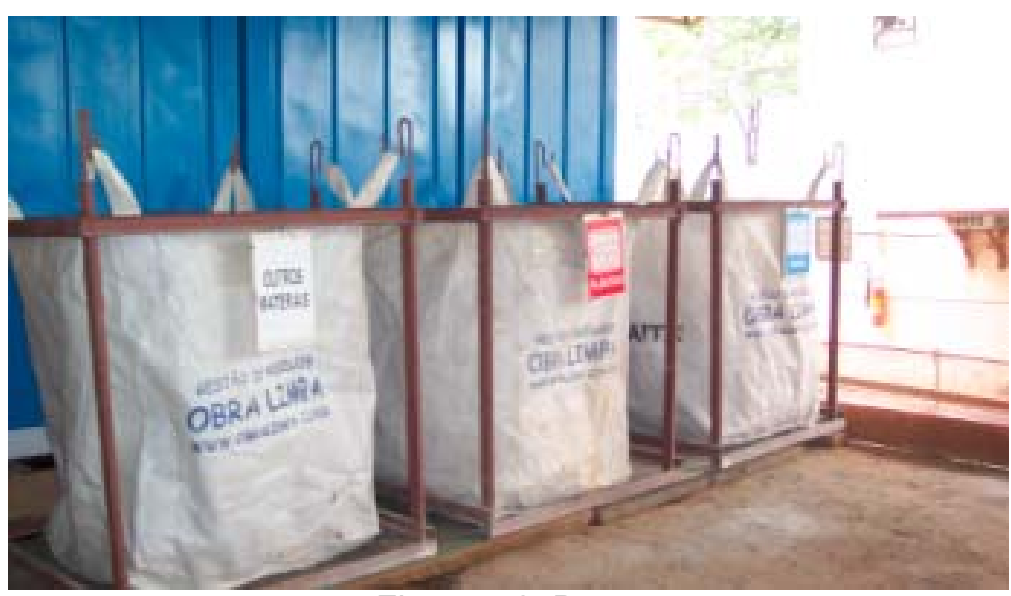

Figura 4.2. Bags.

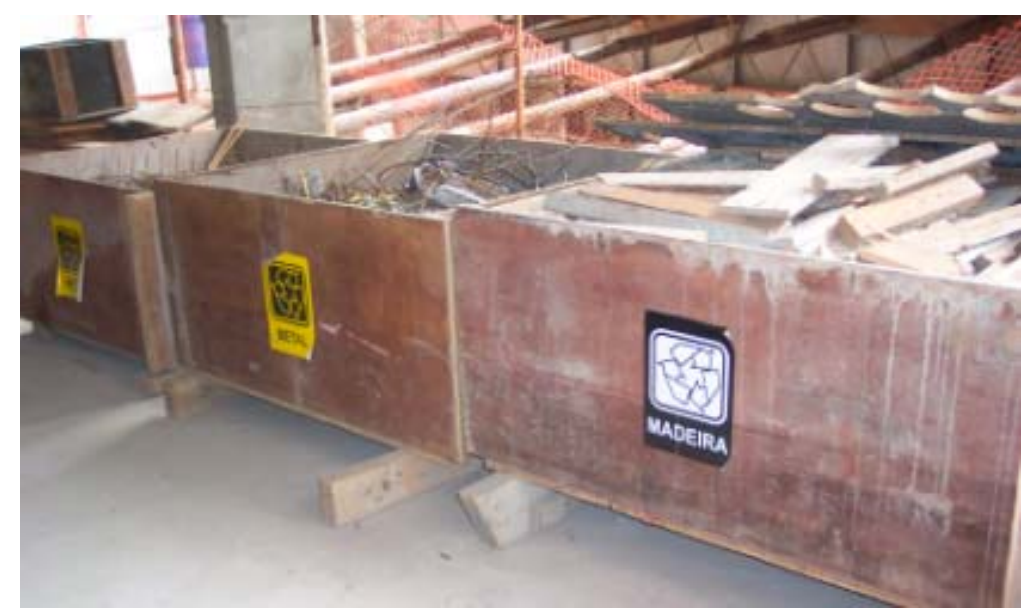

Figura 4.3. Baias. 


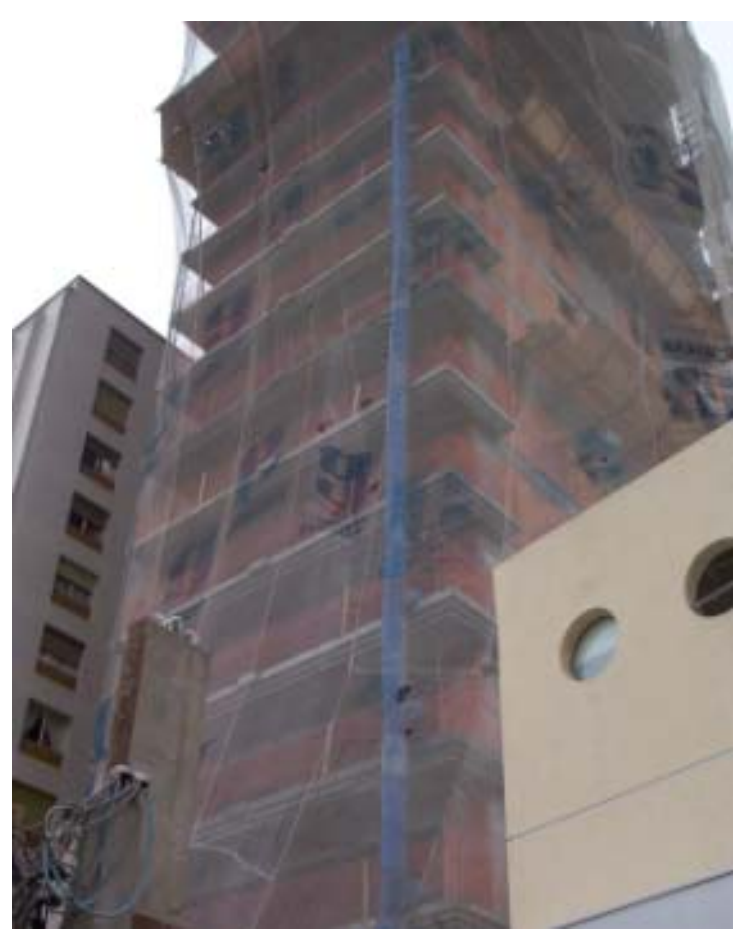

Figura 4.4. Duto para Classe A.

Com os resíduos armazenados no térreo da obra, são acionadas diversas empresas para sua retirada, de acordo com o material específico que cada uma retira. Essas empresas são cadastradas previamente pela Construtora e recebem um boleto de responsabilidade de destinação, que deve ser assinado e carimbado no ponto de depósito final, garantindo que cada resíduo foi encaminhado de forma condizente com a Resolução CONAMA. O pagamento desses prestadores de serviço só ocorreu com a apresentação desse comprovante e, no caso do plástico e papel, a devolução dos bags. Para melhor entendimento, segue um modelo esquemático do processo no canteiro: 


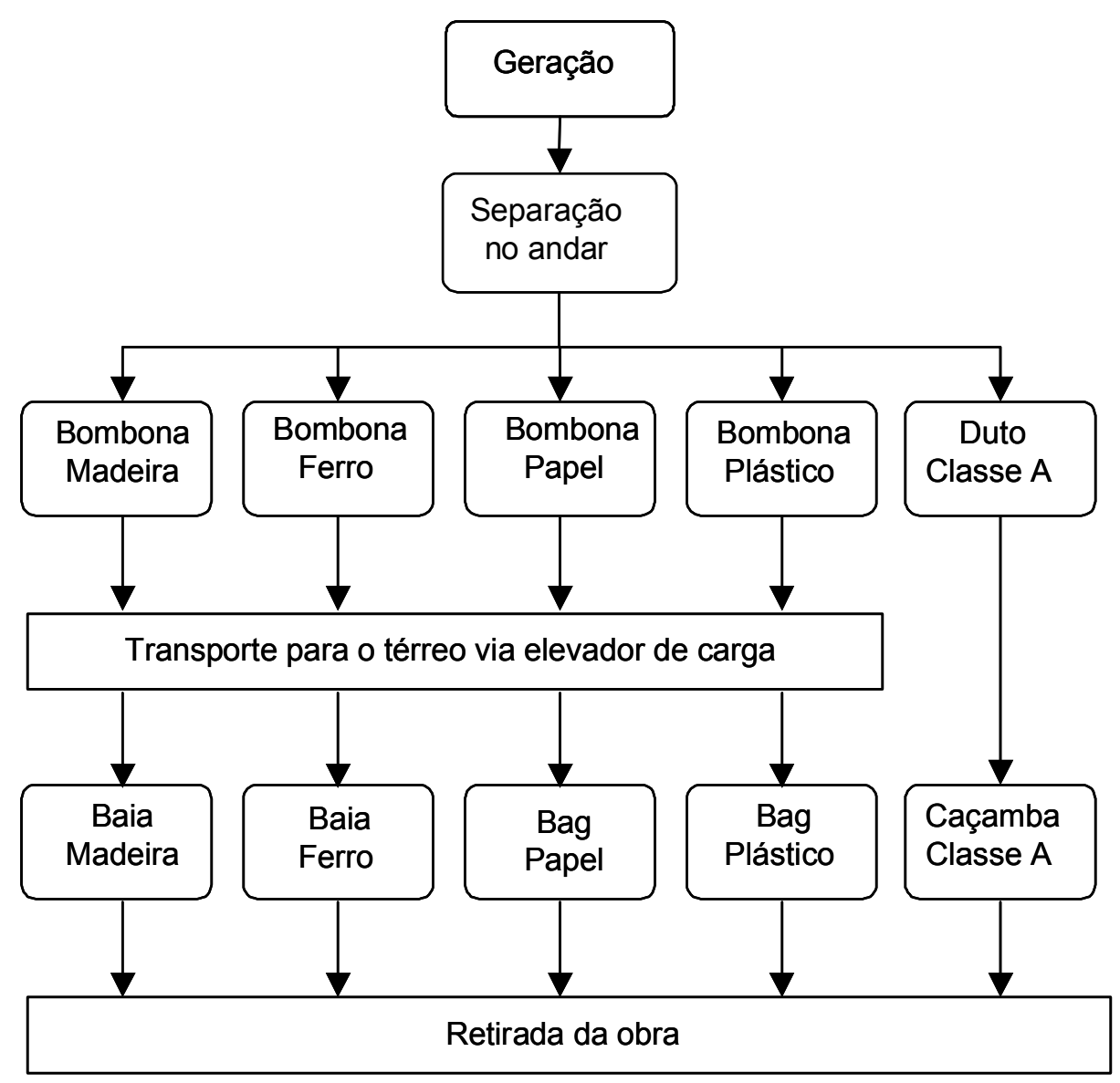

Figura 4.5. Separação e transporte dos resíduos dentro da obra.

\subsection{CONTROLE DE ADEQUAÇÃO DOS PROCEDIMENTOS}

A auditoria do Plano de Gestão de Resíduos foi realizada, a princípio, pela equipe da Consultoria. Eles visitaram a obra quinzenalmente, porém em dias e horários diferentes, com o objetivo de evitar que a limpeza se acumule e aconteça somente perto da visita. Nessas visitas foi feito um check-list das condições em cada andar da obra, observando dois critérios: limpeza e segregação. Para cada laje foi dada uma nota em cada critério, e essas notas são ponderadas pela área da laje em relação ao total do empreendimento. No início da obra, pelo fato de poucas lajes estarem construídas, existia também a ponderação entre critérios, sendo a segregação mais importante que a limpeza. Conforme a obra avançou, essa diferença foi diminuindo até ambos critérios possuírem o mesmo peso. 
Paralelo a isso a Construtora, através de um engenheiro externo à obra, realizava seu próprio check-list quinzenalmente, de forma alternada a da Obra Limpa. Assim, a obra foi verificada semanalmente através dos mesmos critérios, e os problemas detectados tiveram um prazo menor para sua exposição e solução. A Construtora definiu como meta que a nota de limpeza e segregação deveria estar sempre acima de oito. Caso em uma vistoria essa nota fosse inferior, a diferença deveria ser obrigatoriamente compensada na próxima vistoria, isto é, caso uma vistoria tenha tido nota 7,25 , na próxima a nota mínima aceitável sobe de 8,0 para 8,75. Esse controle de metas foi de responsabilidade do Engenheiro Responsável pela obra, que cobrava isso do Engenheiro Residente.

\subsection{MATERIAIS SEM DESTINAÇÃO DEFINIDA}

Como pôde ser observado durante o trabalho, alguns materiais não foram tratados no que se refere a sua destinação, como produtos relacionados com a impermeabilização, pintura, desmoldantes, solventes e gesso. Alguns desses produtos não foram utilizados na obra atual, e aqueles que foram gerados foram encaminhados à coleta pública. Fica claro, porém, que todos esses produtos que não tem destinação definida estão dentro das classificações $C$ e $D$.

Isso ocorre porque, na verdade, essa destinação ainda não foi decidida. A lei municipal da cidade de São Paulo, que será uma das pioneiras a regulamentar a Resolução 307 no país, ainda não foi finalizada, faltando assim a indicação de como esses resíduos serão tratados. Paralelo a isso estão ocorrendo diversos grupos de trabalho organizados pelo Sinduscon-SP entre as construtoras do Programa Piloto e os sindicatos que representam os fabricantes desses produtos, como a ABRAFATI Associação Brasileira de Fabricantes de Tintas; SINDUSGESSO - Sindicato da Indústria do Gesso, ABRAGESSO - Associação Brasileira dos Fabricantes de Blocos e Chapas de Gesso e o IBI - Instituto Brasileiro de Impermeabilização. O objetivo desses grupos de trabalho é traçar, junto com os fornecedores, uma tática de gerenciamento desses resíduos, responsabilidades e métodos de destinação. 


\subsection{CONCLUSÃO DO CAPÍTULO}

Neste Capítulo foi descrito como foi feita a abordagem à aplicação em um caso utilizando o enfoque sistêmico, através da diferenciação dos níveis estratégico, tático e operacional. Foi tratado também o controle da adequação dos procedimentos aplicados, bem como os materiais sem destinação definida.

No nível estratégico foi detalhado o envolvimento da direção da Construtora no Plano de Gestão de Resíduos, bem como os motivos da tomada da decisão por executá-lo.

O nível tático tratou das ações tomadas pelo departamento de engenharia, que foi responsável pela viabilização da redução, segregação e destinação do resíduo. Isso foi feito através de alterações nos projetos, introdução de novos métodos construtivos, determinação de responsabilidades e conscientização dos funcionários.

No nível operacional, foi aplicado o modelo proposto pelas consultorias para o Sinduscon de São Paulo. Esse modelo trata na prática da segregação, acondicionamento e transporte do resíduo, explicando como isso deve ser feito e quais dispositivos são necessários.

O controle de adequação dos procedimentos tratou da fiscalização e auditoria da aplicação do Plano de Gestão de Resíduos no nível operacional, e o item materiais sem destinação definida explica como foram tratados os resíduos que não se encaixam no Plano aplicado, bem como o motivo disso. 


\section{CAPÍTULO 5. RESULTADOS DA APLICAÇÃO EM UM CASO}

\subsection{INTRODUÇÃO}

Para obtenção dos resultados, houve o controle de toda documentação gerada no período de obra do Edifício Piloto. Com isso, todas as retiradas de resíduo da obra, bem como a documentação que comprova a deposição final desses resíduos foi mantida, para possibilitar a análise e gerar um histórico da aplicação do Plano de Gestão. Da mesma forma, foram mantidos todos os relatórios da auditoria de limpeza e segregação dos resíduos.

Os dados do Edifício Controle foram obtidos nos arquivos da Construtora, através da conferência de notas fiscais emitidas pela empresa removedora de resíduos. Dessa forma, foi possível contabilizar a quantidade total de caçambas retiradas durante o período de obra.

\subsection{RESULTADOS}

Ao término da obra, a geração de Resíduos no Edifício Piloto foi:

Tabela 5.1. Resíduos no Edifício Piloto.

\begin{tabular}{c|cc} 
Resíduos & Quantidade & Unidade \\
\hline Papel & 1830 & $\mathrm{~kg}$ \\
Plástico & 1040 & $\mathrm{~kg}$ \\
Metal & 3130 & $\mathrm{~kg}$ \\
Madeira & 308 & $\mathrm{~m}^{3}$ \\
Terra & 248 & $\mathrm{~m}^{3}$ \\
Alvenaria e concreto & 328 & $\mathrm{~m}^{3}$
\end{tabular}

Para facilitar o tratamento desses dados, devemos transformar a unidade dos resíduos plástico, papel e metal de quilos para metros cúbicos. Para isso, foi levantado na obra o peso dos bags de papel e plástico, que têm um metro cúbico de volume. Para o metal 
essa medição não foi feita porém, indiretamente, consegue-se esse valor através da massa nominal do aço, de $7.850 \mathrm{~kg} / \mathrm{m}^{3}$, e da quantidade de vazios calculada em $85 \%$, chegando a seguinte conversão:

Tabela 5.2. Conversão de quilo para metro cúbico.

\begin{tabular}{c|c} 
Resíduos & Conversão $\mathrm{kg} / \mathrm{m}^{3}$ \\
\hline Papel & 47,5 \\
Plástico & 30 \\
Metal & $1.177,5$
\end{tabular}

Aplicando esses valores na Tabela 2, temos:

Tabela 5.3. Resíduos do Edifício Piloto em metros cúbicos.

\begin{tabular}{c|cc} 
Resíduos & Quantidade & Unidade \\
\hline Papel & 38,5 & $\mathrm{~m}^{3}$ \\
Plástico & 34,7 & $\mathrm{~m}^{3}$ \\
Metal & 2,7 & $\mathrm{~m}^{3}$ \\
Madeira & 308,0 & $\mathrm{~m}^{3}$ \\
Terra & 248,0 & $\mathrm{~m}^{3}$ \\
Alvenaria e concreto & 328,0 & $\mathrm{~m}^{3}$ \\
\hline TOTAL & $\mathbf{9 5 9 , 9}$ & $\mathbf{m}^{3}$
\end{tabular}

No Edifício Controle, a geração de resíduos foi:

Tabela 5.4. Resíduos no Edifício Controle.

\begin{tabular}{c|cc} 
Resíduos & Quantidade & Unidade \\
\hline Todos & 856 & $\mathrm{~m}^{3}$
\end{tabular}

Lembrando que, no Edifício Controle, não havia separação dos resíduos. 


\subsection{ANÁLISE DOS OBJETIVOS}

Analisando os objetivos traçados no problema, temos:

1- Redução da geração de resíduos, considerando como medida de efetividade índices de geração de resíduos nos dois Edifícios:

Para comparar a geração de resíduo dos dois edifícios, alguns critérios devem ser observados, que levam em conta a similaridade entre ambos. Como citado na Introdução do Capítulo 4, ambos os edifícios são residenciais multifamiliares de alto padrão, construídos pela mesma Construtora, na mesma região de São Paulo, com as mesmas tecnologias de construção. Isso posto, é necessário comparar dois fatores que influenciam na geração de resíduos: densidade de paredes e de área molhada (cozinha, sanitários e área de serviço). Essa comparação é apresentada abaixo:

Tabela 5.5. Comparativo de densidades de parede e área molhada

\begin{tabular}{c|ccccc} 
Edifício & $\begin{array}{c}\text { Área do } \\
\text { Pavimento } \\
\left(\mathrm{m}^{2}\right)\end{array}$ & $\begin{array}{c}\text { Área de Parede } \\
\left(\mathrm{m}^{2}\right)\end{array}$ & $\begin{array}{c}\text { Área Molhada } \\
\left(\mathrm{m}^{2}\right)\end{array}$ & $\begin{array}{c}\text { Densidade de } \\
\text { Paredes } \\
\left(\mathrm{m}^{2} / \mathrm{m}^{2} \text { de área }\right)\end{array}$ & $\begin{array}{c}\text { Densidade de } \\
\text { Área Molhada } \\
\left(\mathrm{m}^{2} / \mathrm{m}^{2} \text { de área }\right)\end{array}$ \\
\hline Controle & 168,88 & 214,50 & 25,21 & 1,27 & 0,149 \\
Piloto & 188,57 & 231,00 & 29,03 & 1,23 & 0,154
\end{tabular}

Com a Tabela acima, percebe-se que tanto a densidade de paredes como a de área molhada são muito próximas, tendo uma diferença de $3 \%$ entre os edifícios. Assim, será considerado que essa pequena diferença não influencia na geração de resíduos.

A comparação de geração de resíduos pode ser feita através de três diferentes indicadores: volume de resíduo gerado por metro quadrado de construção; massa de resíduo gerado por metro quadrado de construção; e a relação, em porcentagem, da massa total de resíduo em comparação com a massa do edifício. Iremos analisar esses três indicadores:

- Volume de resíduo gerado por metro quadrado de construção: Temos, como resultado, a tabela indicada abaixo: 
Tabela 5.6. Comparativo de geração de resíduos por volume.

\begin{tabular}{c|ccc} 
Edifício & Resíduo $\left(\mathrm{m}^{3}\right)$ & Área $\left(\mathrm{m}^{2}\right)$ & $\mathrm{m}^{3} / \mathrm{m}^{2}$ \\
\hline Controle & 856,0 & 4307 & 0,199 \\
Piloto & 959,9 & 5453 & 0,176
\end{tabular}

Nota-se, assim, que houve uma redução de $11,5 \%$ no volume de resíduo gerado por metro quadrado do edifício.

- Massa de resíduo gerado por metro quadrado de construção: Para calcular esse índice, é necessário converter os volumes mensurados em massa. Assim, serão utilizados os seguintes valores:

Tabela 5.7. Conversão de metros cúbicos para quilo.

\begin{tabular}{c|c} 
Resíduos & Conversão $\mathrm{kg} / \mathrm{m}^{3}$ \\
\hline Resíduo misturado & $1.200,0$ \\
Papel & 47,5 \\
Plástico & 30,0 \\
Metal & $1.177,5$ \\
Madeira & 350,0 \\
Mineral & $1.200,0$ \\
Terra & $1.400,0$
\end{tabular}

Assim temos, para o Edifício Controle:

Tabela 5.8. Cálculo da geração de resíduos em $\mathrm{kg} / \mathrm{m}^{2}-$ Ed. Controle

\begin{tabular}{c|ccccc} 
Edifício Controle & Resíduo $\left(\mathrm{m}^{3}\right)$ & Conversão $\left(\mathrm{kg} / \mathrm{m}^{3}\right)$ & Resíduo $(\mathrm{kg})$ & Área $\left(\mathrm{m}^{2}\right)$ & $\mathrm{kg} / \mathrm{m}^{2}$ \\
\hline Resíduo misturado & 856,0 & $1.200,0$ & $1.027 .200,0$ & $4.307,0$ & 238,5
\end{tabular}


E, para o Edifício Piloto:

Tabela 5.9. Cálculo da geração de resíduos em $\mathrm{kg} / \mathrm{m}^{2}-$ Ed. Piloto

\begin{tabular}{c|ccccc} 
Edifício Piloto & Resíduo $\left(\mathrm{m}^{3}\right)$ & Conversão $\left(\mathrm{kg} / \mathrm{m}^{3}\right)$ & Resíduo $(\mathrm{kg})$ & Área $\left(\mathrm{m}^{2}\right)$ & $\mathrm{kg} / \mathrm{m}^{2}$ \\
\hline Papel & 38,5 & 47,5 & $1.830,0$ & $5.453,0$ & 0,3 \\
Plástico & 34,7 & 30,0 & $1.040,0$ & $5.453,0$ & 0,2 \\
Metal & 2,7 & $1.177,5$ & $3.130,0$ & $5.453,0$ & 0,6 \\
Madeira & 308,0 & 350,0 & $107.800,0$ & $5.453,0$ & 19,8 \\
Mineral & 328,0 & $1.200,0$ & $393.600,0$ & $5.453,0$ & 72,2 \\
Terra & 248,0 & $1.400,0$ & $347.200,0$ & $5.453,0$ & 63,7 \\
\hline TOTAL & $\mathbf{9 5 9 , 9}$ & & $\mathbf{8 5 4 . 6 0 0 , 0}$ & $\mathbf{5 . 4 5 3 , 0}$ & $\mathbf{1 5 6 , 7}$
\end{tabular}

Comparando a massa de resíduo gerado por metro quadrado, houve uma redução de $34,3 \%$ de geração no Edifício Piloto.

- Massa total de resíduo em comparação com a massa total do edifício: Para esse índice, o cálculo da massa do edifício será feito somando a massa de concreto utilizado (calculado através do consumo previsto nos projetos estruturais) e a massa de paredes. Os valores utilizados para as paredes são de $140 \mathrm{~kg} / \mathrm{m}^{2}$ para as paredes externas e $120 \mathrm{~kg} / \mathrm{m}^{2}$ para as internas.

Tabela 5.10. Comparação da massa de resíduo com a massa total dos Edifícios

\begin{tabular}{c|ccccc} 
Edifício & Concreto (ton) & Paredes (ton) & Massa Total (ton) & Resíduo (ton) & $\%$ (resíduo/total) \\
\hline Controle & 4085,1 & 444,2 & 4529,3 & 1027,2 & $22,7 \%$ \\
Piloto & 5508,0 & 570,0 & 6078,0 & 854,6 & $14,1 \%$
\end{tabular}

A redução de $8,6 \%$ na taxa de geração indica, novamente, que houve redução da geração de resíduos. É importante frisar que as porcentagens apresentadas na tabela acima não representam o valor absoluto de perda de materiais, e sim um valor relativo, pois na massa do edifício levou-se em conta apenas o volume de concreto e alvenaria. Da mesma forma, na massa de resíduos está computada a terra escavada para os subsolos, que não representa perdas.

2- Do resíduo gerado, reduzir a quantidade encaminhada para deposição final, reduzindo assim o impacto ao meio ambiente. 
O resíduo do Edifício Controle foi 100\% encaminhado para deposição final. Já no Edifício Piloto o papel, o plástico, a madeira e o metal foram encaminhados para reciclagem. A soma desses quatro tipos de resíduos é de $383,8 \mathrm{~m}^{3}$, de um total de $967,8 \mathrm{~m}^{3}$ de resíduos gerados. Dessa forma, foi encaminhado para reciclagem 39,7\% do volume de resíduo. Para que essa reciclagem fosse possível, era crucial a limpeza e posterior segregação do resíduo gerado na obra. Esses fatores foram analisados pela Consultoria e pela própria Construtora, que faziam essa avaliação através de um formulário específico, representado no Anexo IV, e pontuavam esses critérios em uma escala de 0 a 10 . Os resultados do Edifício Piloto foram:

Gráfico 5.1. Avaliação de Limpeza e Segregação.

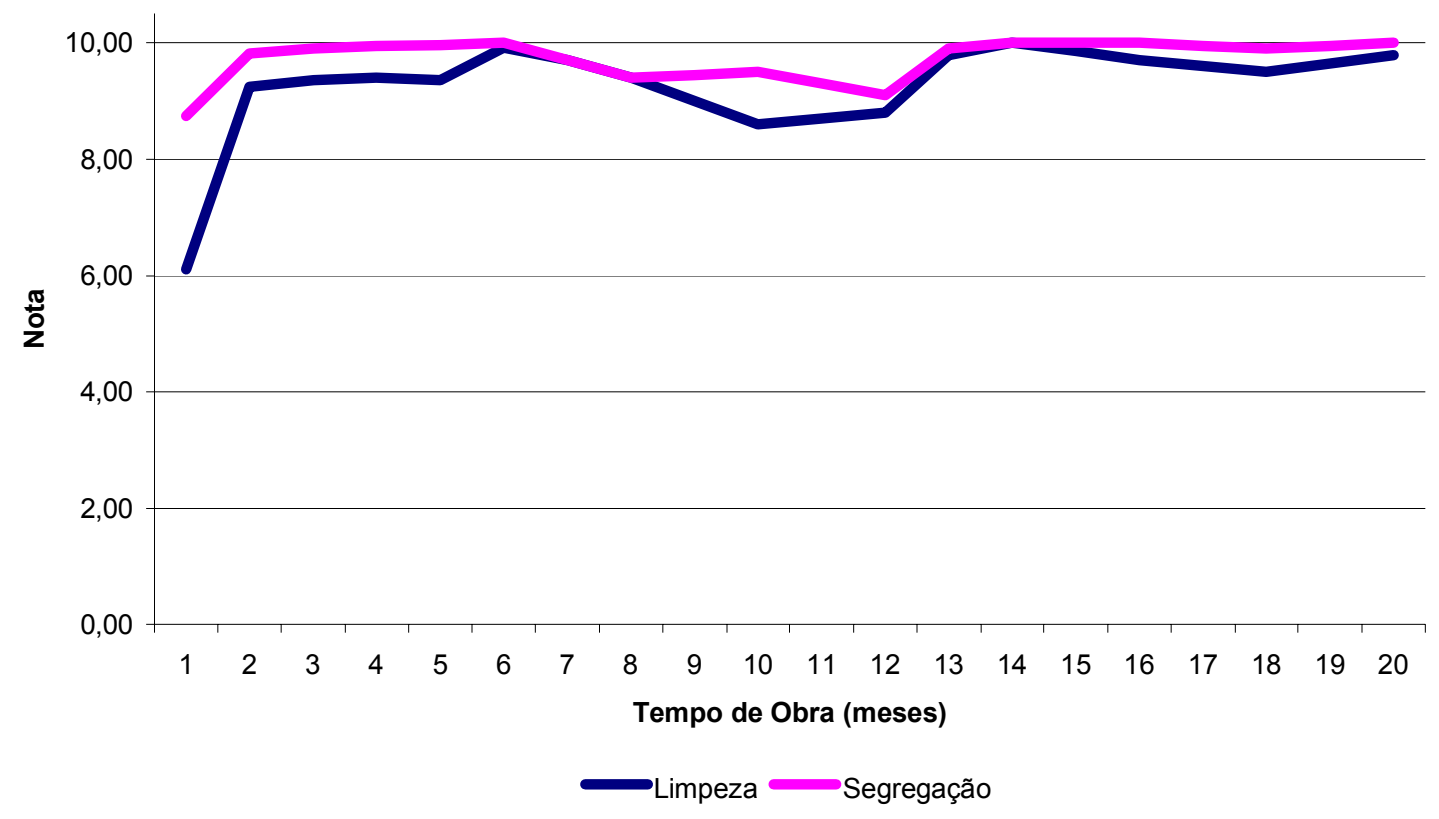

Percebe-se, através do Gráfico 1, que somente uma vez uma das notas foi abaixo de oito, que era a meta da Construtora. As médias das notas representadas no gráfico foram 9,2 para limpeza e 9,7 para segregação.

3- Rastreabilidade, através de documentação, que o envio de todo o resíduo para reciclagem ou deposição final foi feito cumprindo a legislação. 
Para garantir a rastreabilidade do encaminhamento do resíduo, foi feito o trabalho de inicialmente, cadastrar fornecedores. As empresas cadastradas necessariamente tinham autorização dos órgãos competentes para receber a Classe de resíduo que seria destinado a ele. O cadastro foi feito através do formulário no Anexo III. O transporte do resíduo era feito somente por transportadoras filiadas ao SIERESP (Sindicato das Empresas de Recolhimento de Entulho do Estado de São Paulo), o que garantia o aspecto de legalidade da empresa, já que diversos transportadores no mercado atuam de forma ilegal. Para controlar que esses transportadores estavam levando o resíduo ao local determinado pela Construtora, era preenchido um documento chamado "Ficha de Remoção e Destinação de Resíduos" (Anexo II), onde constam os dados da empresa geradora, o tipo e quantidade de resíduo transportado, os dados da empresa transportadora (inclusive com a placa do veículo que retirou aquele resíduo) e os dados do local de recebimento. Esse documento era levado pela transportadora e deveria ser devolvido com a assinatura e o carimbo do local de recebimento. Só assim a Construtora autorizava a emissão da nota fiscal e pagava pelo serviço.

Do resíduo gerado no Edifício Piloto, sua totalidade seguiu esse procedimento no momento de reciclagem ou deposição final. Dessa forma, existe a rastreabilidade de todo resíduo gerado no empreendimento, para o caso de alguma fiscalização ou então alguma acusação de deposição ilegal de resíduo.

4- Redução do custo de tratamento do resíduo como um todo, mostrando a viabilidade financeira do Plano.

O custo relacionado aos resíduos do Edifício Piloto depende do tipo de resíduo. O papel, o plástico e o metal eram vendidos para reciclagem, sendo que o comprador retirava o material na própria obra, quando uma quantidade mínima, combinada entre as partes, estivesse armazenada. Os valores de venda foram:

Tabela 5.11. Valores de venda dos resíduos recicláveis.

\begin{tabular}{c|c} 
Resíduos & Valor de venda $(\mathrm{R} \$ / \mathrm{kg})$ \\
\hline Papel & 0,07 \\
Plástico & 0,07 \\
Metal & 0,10
\end{tabular}


A madeira, a terra e a alvenaria e concreto eram retirados em caçambas de $4 \mathrm{~m}^{3}$. $\mathrm{O}$ custo da caçamba de madeira foi de $\mathrm{R} \$ 75,00$ por caçamba, enquanto que para os outros materiais foi de $\mathrm{R} \$ 90,00$. Essa diferença ocorreu pois a madeira era reciclada, porém a empresa que reutilizava esse material não pagava por ele. Assim, os $\mathrm{R} \$ 75,00$ são relativos ao custo de transporte. Nos outros materiais, a diferença de preço está relacionada ao custo da taxa de deposição final do resíduo, cobrada pelo local que recebia o material. Dessa forma, os custos foram:

Tabela 5.12. Custos do Edifício Piloto.

\begin{tabular}{c|cc|rr|rr} 
Resíduos & Quantidade Unidade & Custo $\left(\mathrm{R} \$ / 4 \mathrm{~m}^{3}\right)$ & $\begin{array}{c}\text { Total Custo } \\
(\mathrm{R} \$)\end{array}$ & Receita $(\mathrm{R} \$ / \mathrm{kg})$ & $\begin{array}{r}\text { Total Receita } \\
(\mathrm{R} \$)\end{array}$ \\
\hline Papel & 1830 & $\mathrm{~kg}$ & & & 0,07 & 128,10 \\
Plástico & 1040 & $\mathrm{~kg}$ & & & 0,07 & 72,80 \\
Metal & 3130 & $\mathrm{~kg}$ & & & 0,10 & 313,00 \\
Madeira & 308 & $\mathrm{~m}^{3}$ & 75,00 & 5775,00 & & \\
Terra & 248 & $\mathrm{~m}^{3}$ & 90,00 & 5580,00 & & \\
Alvenaria e concreto & 328 & $\mathrm{~m}^{3}$ & 90,00 & 7380,00 & & $\mathbf{R} \mathbf{5 1 3 , 9 0}$
\end{tabular}

Vale lembrar que a receita da venda dos produtos para reciclagem foi direcionada para os funcionários, já que os prêmios do concurso "equiporcão" foram pagos com esse dinheiro. Dessa forma ela não é computada como economia dentro do processo.

Outro fator que deve ser considerado é que, para o Plano de Gestão de Resíduos, foi necessária a compra de equipamentos como bombonas, sacos de ráfia, bags e etiquetas de identificação. Esse material teve o custo de $R \$ 1.270,00$. Deve ser considerado também que, como citado anteriormente, o trabalho de limpeza e segregação foi feito pelos próprios funcionários da obra. Não foi necessária a contratação de pessoas para realizar esse trabalho e durante toda a obra não houve queda de produtividade dos trabalhos, isto é, a limpeza e segregação foram incorporadas dentro das atividades sem prejudicá-las. Assim, não houve custos extras de mão-de-obra ou perda de produtividade.

Considerando as informações acima, o custo total do Plano de Gestão de Resíduos foi de $\mathrm{R} \$ 20.005,00$. 


\subsection{CONCLUSÃO DO CAPÍTULO}

Os resultados da aplicação demonstraram que os três primeiros objetivos tiveram bons resultados, mostrando que o Plano de Gestão de Resíduos é viável. É interessante notar as diferentes medidas de efetividade da redução de resíduos. A redução da geração de resíduos em volume foi de $11,5 \%$, enquanto a redução em massa foi de $34,3 \%$. Isso indica que a Plano de Gestão provavelmente alterou a composição do resíduo gerado havendo, no Edifício Piloto, menor participação dos resíduos mais pesados. Isso é reflexo da redução do resíduo mineral, causada pela maior racionalidade e paginação da alvenaria e dos acabamentos e a não necessidade de cortar a alvenaria para instalar os sistemas prediais.

Para analisar a última medida de efetividade, o custo, será necessário explorar o que ocorreria com o Edifício Piloto caso o Plano de Gestão de Resíduos não fosse implantado, ou se somente parte dele fosse realizada. Para isso, é necessário executar a simulação do modelo no programa Arena. Essa simulação será tratada em detalhe no próximo Capítulo.

Analisando os resultados apresentados, percebe-se que o Plano de Gestão de Resíduos atingiu os objetivos que foram propostos. Apesar disso, esse não foi um resultado uniforme dentre as onze Construtoras que participaram do primeiro Grupo de Trabalho sobre Resíduos de Construção Civil. Um dos itens que serve como exemplo é a limpeza e segregação dos resíduos gerados, onde o Edifício Piloto da aplicação em um caso se destacou, comparado com um resultado médio e outro insatisfatório, que ocorreram dentro do Grupo de Trabalho:

Tabela 5.13. Comparação de notas de limpeza e segregação.

\begin{tabular}{c|cc} 
Desempenho & Limpeza & Segregação \\
\hline Estudo de Caso & 9,2 & 9,7 \\
Médio & 7,9 & 8,0 \\
Insatisfatório & 5,1 & 5,2
\end{tabular}

Um trabalho muito interessante de avaliação dos resultados foi uma pesquisa realizada (Anexo V) ao fim das atividades do primeiro Grupo de Trabalho a pedido do Sinduscon 
(CAMPOS, 2004). Nessa pesquisa foram entrevistados 70 profissionais participantes desse grupo em diversos cargos hierárquicos dentro das empresas. Dessa pesquisa, vale destacar alguns resultados.

Percebe-se, da análise dos gráficos no Anexo V, que em geral para o Grupo de Trabalho os resultados também foram positivos.

Vale discutir, então, o porquê da aplicação em um caso ter tido mais sucesso do que a média das onze construtoras. O principal elemento, sem dúvida alguma, foi o comprometimento da Construtora na execução do Plano de Gestão de Resíduos. O trabalho de conscientização e treinamento dos funcionários era reforçado semanalmente em reuniões de equipe, onde os resultados do Plano eram apresentados e as falhas detectadas discutidas. Dos principais problemas apontados, essas reuniões atingiam três itens: conscientização do pessoal, falhas do treinamento e envolvimento da equipe. Não houve dificuldades sérias na destinação e a rotatividade de terceiros na obra foi pequena, garantindo a estabilidade do conhecimento. Ao final do Plano os funcionários da obra afirmaram ter orgulho de ter participado desse projeto. 


\section{CAPÍTULO 6. MODELAGEM}

\subsection{INTRODUÇÃO}

Apesar dos resultados da aplicação em um caso demonstraram sua viabilidade, eles foram obtidos através da conjuntura de dois fatores: a redução do resíduo gerado e a segregação com destinação para reciclagem.

Para avaliar o que aconteceria caso ocorresse apenas um desses fatores e melhores políticas de transporte, foi desenvolvido o modelo do Edifício Piloto utilizando o programa Arena 7.0, da Rockwell Software. O Arena é um programa de simulação onde um processo é modelado e pode-se simular diferentes resultados variando os dados iniciais do modelo.

A modelagem, no Arena, é feita através de uma linguagem semelhante a um fluxograma. Assim, o modelo é constituído de formas geométricas que representam procedimentos, decisões a serem tomadas e início e término de processos. Ao construir esse fluxograma utilizando os módulos disponíveis no Arena, cria-se o caminho que a parte dinâmica do sistema, ou seja, aquilo que se movimenta dentro do sistema (no nosso caso o resíduo) percorre. Essa parte que percorre o fluxograma é chamada de entidade, e o fluxograma representa a estrutura estática do sistema (Paragon, 1998).

\subsection{MODELO DO EDIFÍCIO PILOTO}

Conforme descrito na Metodologia, para o desenvolvimento do modelo do Edifício Piloto foram assumidas algumas simplificações, que são a separação da fase de preparação do terreno e fundações e a constância da geração de resíduos durante a execução de cada andar. Assim, as médias de geração são:

Para a fase de preparação do terreno e fundação (61 dias):

- Geração de papel: não há geração; 
- Geração de plástico: não há geração;

- Geração de metal: 1,133197 litros por hora;

- Geração de madeira: 90,16394 litros por hora;

- Geração de mineral: não há geração, pois qualquer resíduo de concreto é incorporado ao solo;

- Geração de terra: 163,934426 litros por hora.

Para a fase de construção dos pavimentos (364 dias por pavimento, iniciando um pavimento a cada 10 dias)

- Geração de papel: 0,661624 litros por hora por pavimento;

- Geração de plástico: 0,595295 litros por hora por pavimento;

- Geração de metal: 0,036247 litros por hora por pavimento;

- Geração de madeira: 4,532967 litros por hora por pavimento;

- Geração de mineral: 5,631868 litros por hora por pavimento;

- Geração de terra: 114,130435 litros por hora, durante mais 184 dias, como movimentação de terra da escavação dos subsolos.

A visualização do modelo completo está no Anexo VI.

\subsubsection{Modelagem da Preparação do Terreno e Fundações e dos Pavimentos}

Inicialmente foi desenvolvida a lógica para a preparação do terreno e fundações. A visualização dessa fase no programa ficou como demonstrado na página seguinte: 


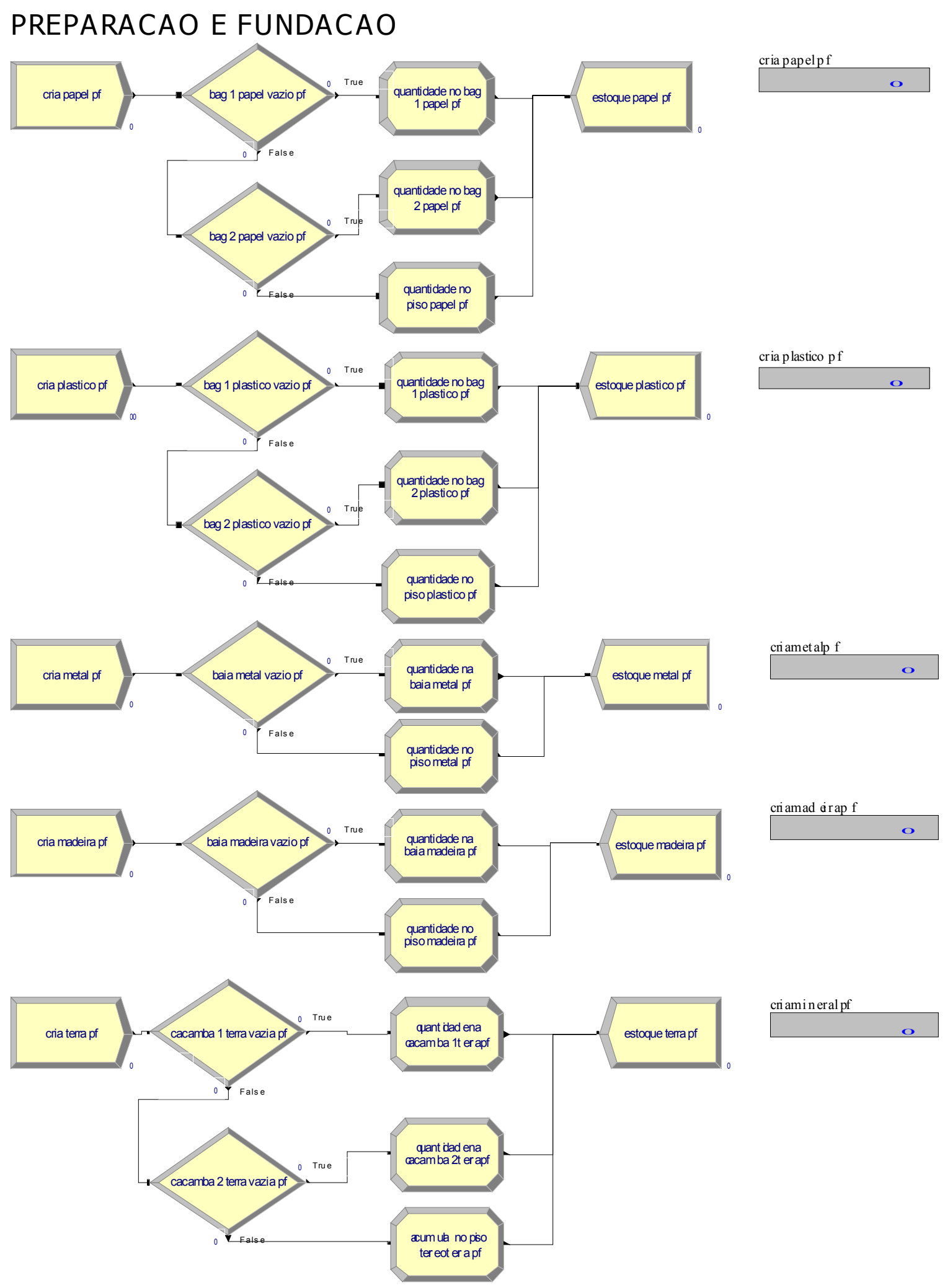

Figura 6.1. Representação da preparação do terreno e fundações do Edifício Piloto. 
A lógica utilizada em todos os resíduos - papel, plástico, terra, metal e madeira - é praticamente idêntica, variando apenas o fato do papel, o plástico e a terra possuírem dois recipientes de armazenamento (bags para papel e plástico e caçambas para terra), enquanto que o metal e a madeira só possuem um recipiente (baia). Dessa forma, será detalhada apenas a lógica utilizada com o papel, já que ela pode ser extrapolada:

- O módulo create chamado "cria papel pf" é responsável por criar uma entidade no na preparação e fundação que representa um litro de papel, obedecendo a distribuição exponencial de geração desse resíduo;

- O módulo decide "bag 1 papel vazio pf" verifica se o bag de papel 1 possui capacidade para receber mais papel. Caso positivo, a entidade é encaminhada ao assign "quantidade no bag 1 papel pf"; caso negativo, é encaminhada ao decide "bag 2 papel vazio pf", que faz a mesma checagem para o bag 2. Se houver capacidade no bag 2, a entidade é encaminhada ao assign "quantidade no bag 2 papel pf"; caso negativo, vai para o assign "quantidade no piso papel pf";

- Os módulos assign "quantidade no bag 1 papel pf", "quantidade no bag 2 papel pf" e "quantidade no piso papel pf" são contadores. Cada vez que uma entidade passa por eles, uma unidade (no caso litro) é somada no respectivo bag ou piso;

- O módulo dispose "estoque papel pf" tem função lógica de retirar a entidade da simulação, e representa que o papel gerado já foi segregado;

- O contador "cria papel pf", registra a quantidade de entidades geradas.

Esse sistema funciona no programa durante 61 dias, como dito anteriormente. A exceção é a geração de terra, que continua por mais 184 dias, representando a continuação das escavações para os subsolos.

\subsubsection{Modelagem dos Pavimentos}

A representação de um pavimento, no Modelo, é feita da seguinte forma: 


\section{ANDAR 1}

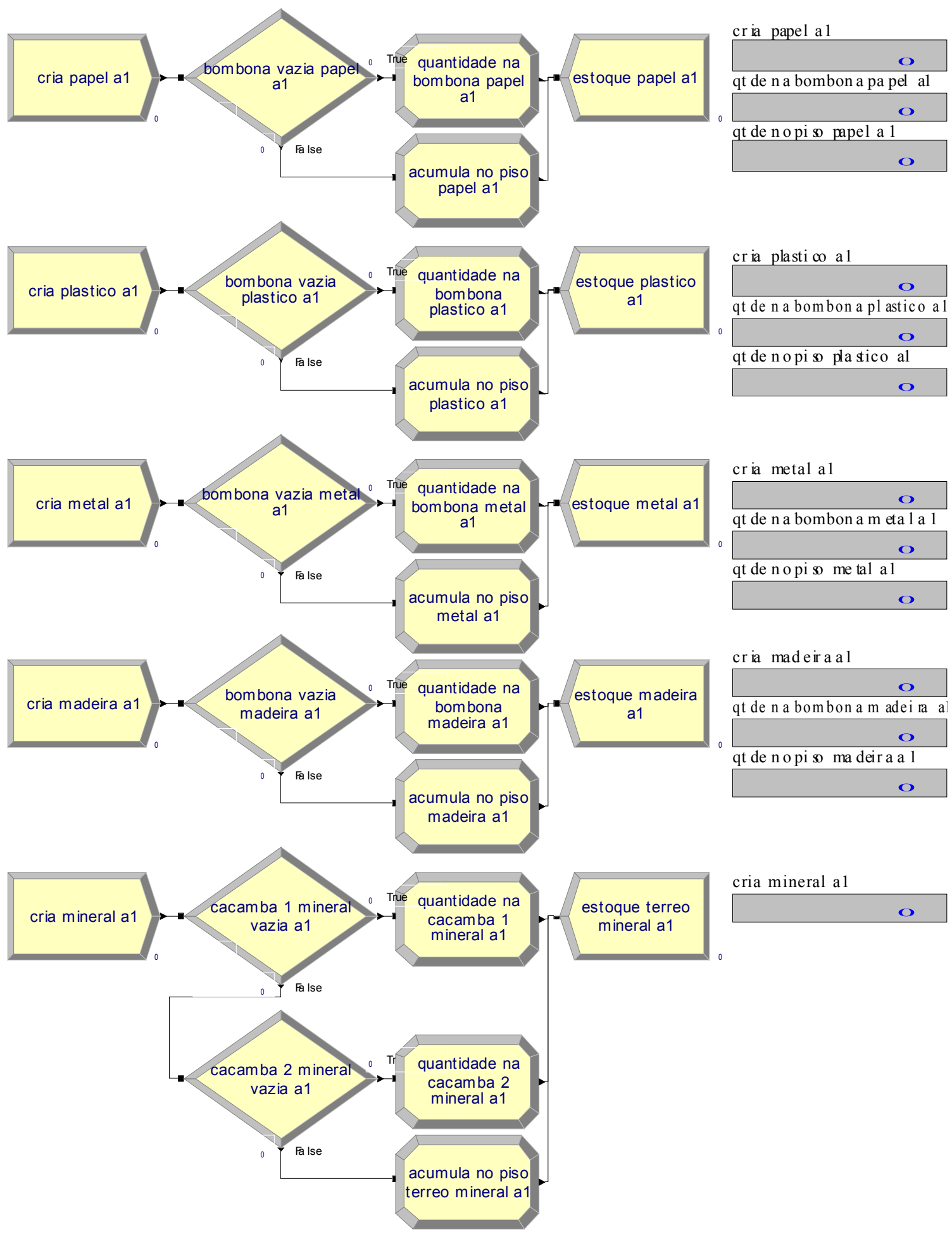

Figura 6.2. Representação de um andar do Edifício Piloto. 
Como anteriormente, a lógica utilizada com os quatro primeiros resíduos - papel, plástico, metal e madeira - são praticamente idênticas. Dessa forma, será detalhada apenas a lógica utilizada com o papel, já que ela pode ser extrapolada para esses outros resíduos.

- O módulo create chamado "cria papel a1" é responsável por criar uma entidade no andar 1 que representa um litro de papel, obedecendo a distribuição exponencial de geração desse resíduo;

- O módulo decide "bombona vazia papel a1" verifica se a bombona de papel localizada no andar possui capacidade para receber mais papel. Caso positivo, a entidade é encaminhada ao assign "quantidade na bombona papel a1"; caso negativo, é encaminhada ao assign "acumula no piso papel a1";

- Os módulos assign "quantidade na bombona papel a1" e "acumula no piso papel a1" são contadores. Cada vez que uma entidade do andar 1 passa por eles, uma unidade (no caso litro) é somada na respectiva bombona ou piso;

- O módulo dispose "estoque papel a1" tem função lógica de retirar a entidade da simulação, e representa que o papel gerado no andar 1 já foi segregado;

- Os contadores "cria papel a1", "qtde na bombona papel a1" e "qtde no piso papel a1" registram a quantidade de entidades geradas no andar, quantos litros estão na bombona e qual a quantidade de resíduo no piso.

No Edifício Piloto o tratamento dado ao resíduo Classe A, ou mineral, difere dos outros resíduos pelo fato dele ser transportado diretamente ao térreo através de um duto. Assim, a lógica utilizada no programa é:

- O módulo create chamado "cria mineral a1" é responsável por criar uma entidade no andar 1 que representa um litro de resíduo, obedecendo a distribuição exponencial discutida acima; 
- O módulo decide "cacamba 1 mineral vazia a1" é um módulo meramente lógico. Como o resíduo é encaminhado por duto até o térreo, ele verifica se a primeira (de duas) caçambas localizada no térreo ainda tem capacidade para receber o resíduo gerado no andar 1. Caso positivo, a entidade é encaminhada para o módulo assign "quantidade na cacamba 1 mineral a1"; caso a caçamba 1 esteja em seu limite de capacidade de 4.000 litros, ele encaminha a entidade para o decide "cacamba 2 mineral vazia a1";

- O módulo decide "cacamba 2 mineral vazia a1" faz a mesma checagem, porém com a caçamba 2. Caso positivo, a entidade é encaminhada para o módulo assign "quantidade na cacamba 2 mineral a1"; caso a caçamba 2 esteja cheia, a entidade é encaminhada para o assign "acumula no piso terreo mineral a1";

- Os módulos assign "quantidade na cacamba 1 mineral a1", "quantidade na cacamba 2 mineral a1" e "acumula no piso terreo mineral a1" são contadores. Cada vez que uma entidade do andar 1 passa por eles, uma unidade (no caso litro) é somada na respectiva caçamba ou piso.

- O módulo dispose "estoque terreo mineral a1" também tem função lógica de retirar a entidade da simulação, e representa que aquele resíduo do andar 1 já está no térreo.

- O contador "cria mineral a1" registra a quantidade de entidades geradas no andar, para mera conferência.

Com isso, o modelo dos andares foi replicado dessa forma até completar os vinte pavimentos do Edifício Piloto.

\subsubsection{Modelagem da Retirada do Resíduo dos Andares}

O esvaziamento das bombonas nos andares é feito através da grua, que passa, ao final de cada dia, em cada andar iniciando do andar 20. Quando a capacidade da grua é atingida, ela desce ao térreo, descarrega e volta ao ponto onde parou. 
Uma simplificação utilizada no modelo é que a grua não retira parcialmente o resíduo de um andar. Dessa forma, se ela está próxima de sua capacidade máxima e todo o resíduo do próximo andar não cabe na grua, ela retorna ao térreo. A representação da grua no software, devido a sua extensão, não pode ser representada no corpo do trabalho. Porém, sua visualização pode ser feita no Anexo VI. Assim, segue a explicação da lógica utilizada.

- O módulo create "gera grua" cria uma entidade, no caso a grua, a cada oito horas, representando dessa forma a passagem da grua todo final de dia para retirar os resíduos separados nos andares;

- O módulo assign "zera andar" tem função lógica, e atribui o valor zero a variável "saida_grua". A função dessa variável é indicar, na área de visualização, em qual andar a grua atingiu sua capacidade máxima e retornou ao térreo;

- O módulo assign "carrega grua a20" representa a chegada da grua no vigésimo andar. É nesse módulo que o resíduo de cada bombona é retirado do piso para a grua, bem como o resíduo acumulado no piso;

- O módulo decide "cabe na grua a19" verifica se a existe espaço na grua para retirar o resíduo acumulado no décimo nono pavimento. Se afirmativo, a grua é encaminhada para o assign "carrega grua a19"; caso negativo, encaminha para o assign "marca grua a19";

- O módulo assign "carrega grua a19" tem a mesma função que o módulo “carrega grua a20", porém para o andar 19. O encaminhamento a partir desse módulo é sucessivo até o primeiro pavimento, desde que a capacidade máxima da grua não seja atingida; 
- O módulo assign "marca grua a19" representa o retorno da grua ao térreo para descarregar o resíduo, já que a grua atingiu sua capacidade máxima. Esse módulo é repetido em todos os andares, já que existe a possibilidade da grua ter de voltar ao térreo e retornar depois em qualquer dos andares. Esse módulo possui duas funções lógicas. A primeira é dar valor ao atributo "andar_grua", que registra em que andar a grua teve que ir descarregar e, conseqüentemente, em qual ela deve retornar. A segunda função lógica é atribuir um valor a variável "saida_grua", que representa em que andar a grua atingiu sua capacidade máxima e é mostrado nos visualizadores do programa. Após a passagem por esse módulo, a grua atinge o térreo e passa pelo processo de distribuir o resíduo nos elementos de armazenagem do térreo. Nesse ponto, o processamento ocorre na seguinte ordem: papel, plástico, metal e madeira;

- O módulo decide "bag 1 papel vazio" verifica se há espaço para armazenar o papel que estava na grua no primeiro bag de papel. Caso positivo, a entidade é encaminhada ao módulo assign "quantidade no bag 1 papel"; caso negativo, para o módulo decide "bag 2 papel vazio";

- O módulo decide "bag 2 papel vazio" faz a mesma verificação, porém para o segundo bag de papel. Caso exista espaço, o encaminhamento é feito para o módulo assign "quantidade no bag 2 papel". Se isso não for possível, o encaminhamento é feito para o módulo assign "quantidade no piso papel";

- Os módulos assign "quantidade no bag 1 papel", "quantidade no bag 2 papel" e "quantidade no piso papel" são os contadores responsáveis por registrar a quantidade de papel em cada uma desses dispositivos ou no piso. Independente por qual módulo a entidade passe, ela é encaminhada depois para o tratamento do resíduo plástico.

O tratamento do resíduo plástico no térreo é idêntico ao do papel. Dessa forma, consideramos a explicação acima válida também para o plástico e passamos para o tratamento do metal, que sucede o do plástico. 
- O módulo decide "baia metal vazio" verifica se há espaço na baia de metal para receber o resíduo trazido pela grua. Não existe uma segunda baia de metal na obra (como no caso do papel e do plástico, com dois bags cada). Dessa forma caso afirmativo, a entidade é encaminhada para o módulo assign "quantidade na baia metal"; caso negativo, para o módulo assign "quantidade no piso metal";

- Os módulos assign "quantidade na baia metal" e "quantidade no piso metal" são os contadores que registram a quantidade de metal na baia ou no piso. Após essa passagem, a entidade é encaminhada para o tratamento do resíduo de madeira;

Da mesma forma que o tratamento do plástico em relação ao papel, o tratamento dado à madeira é idêntico ao do metal. Dessa forma, a explicação acima também é válida para a madeira, e podemos prosseguir ao módulo decide "retorno ao andar".

- O módulo decide "retorno ao andar" verifica o atributo da entidade que diz de que andar a grua retornou. Caso esse atributo tenha valor diferente de zero, a entidade é devolvida ao primeiro andar que ela não atendeu (isso depende do valor do atributo) e o processo acima é retomado. Caso o valor do atributo seja zero, isso significa que a grua passou por todos os andares e assim a entidade é encaminhada para o módulo dispose "fim grua";

- O módulo dispose "fim grua" representa o término do trabalho daquela grua e tem função de retirar a entidade da simulação.

\subsubsection{Modelagem da Retirada dos Resíduos da Obra}

A retirada dos resíduos da obra se dá através de caminhões, que pertencem a diferentes empresas que retiram resíduos específicos. Dessa forma, existe uma empresa que retira resíduo Classe A, ou mineral e terra, uma que retira metal e outra que leva a madeira. 
A exceção se dá em relação ao papel e ao plástico. Como a mesma empresa de reciclagem retirava esse resíduo, no programa foi desenvolvida apenas uma lógica para ambos resíduos.

Uma das simplificações deste modelo é que, para os resíduos de papel, plástico e metal foi considerado que, ao chegar o caminhão à obra, todo o resíduo no térreo era retirado, independente da capacidade do caminhão. Apesar disso ser uma simplificação do modelo, de fato esse procedimento ocorria na obra, a não ser em casos muito específicos. A representação no programa segue na página seguinte.

A retirada do resíduo mineral e de terra obedecem exatamente a mesma lógica, com a diferença que a caçamba de terra era de $20 \mathrm{~m}^{3}$, enquanto a de mineral era de $4 \mathrm{~m}^{3}$. Dessa forma, será descrita somente a lógica da retirada de resíduo mineral:

- O módulo create chamado "cria caminhao mineral" é um módulo lógico, que cria uma única entidade, nesse caso um caminhão;

- O módulo separate "gera caminhão mineral 1 e 2" também tem função lógica. Ele duplica o caminhão, gerando dois caminhões. O objetivo disso é que, como na obra existem duas caçambas, serão chamados no máximo dois caminhões para retirá-las. Esse módulo encaminha um caminhão para o módulo hold "chama caminhao mineral 1" e outro para o hold "chama caminhao mineral 2".

- O módulo hold "chama caminhao mineral 1" aguarda um sinal para liberar o caminhão para o próximo módulo. Esse sinal é dado quando a caçamba 1 mineral atinge sua capacidade máxima. Esse procedimento simula a situação da chamada de um caminhão para retirada de caçamba, que ocorre via telefone quando essa caçamba está no limite. Quando o sinal é dado, a entidade é encaminhada para o módulo process "viagem caminhao mineral 1 para obra";

- O módulo process "viagem caminhao mineral 1 para obra" representa o tempo de atendimento entre a ligação telefônica e a chegada do caminhão na obra. No modelo, esse período foi considerado uma distribuição normal de média oito horas (que no modelo representa um dia) com desvio padrão de uma hora. Após 
esse período, o caminhão é liberado para o próximo módulo, que é o decide "quantidade piso mineral 1";

\section{CAMINHOES}

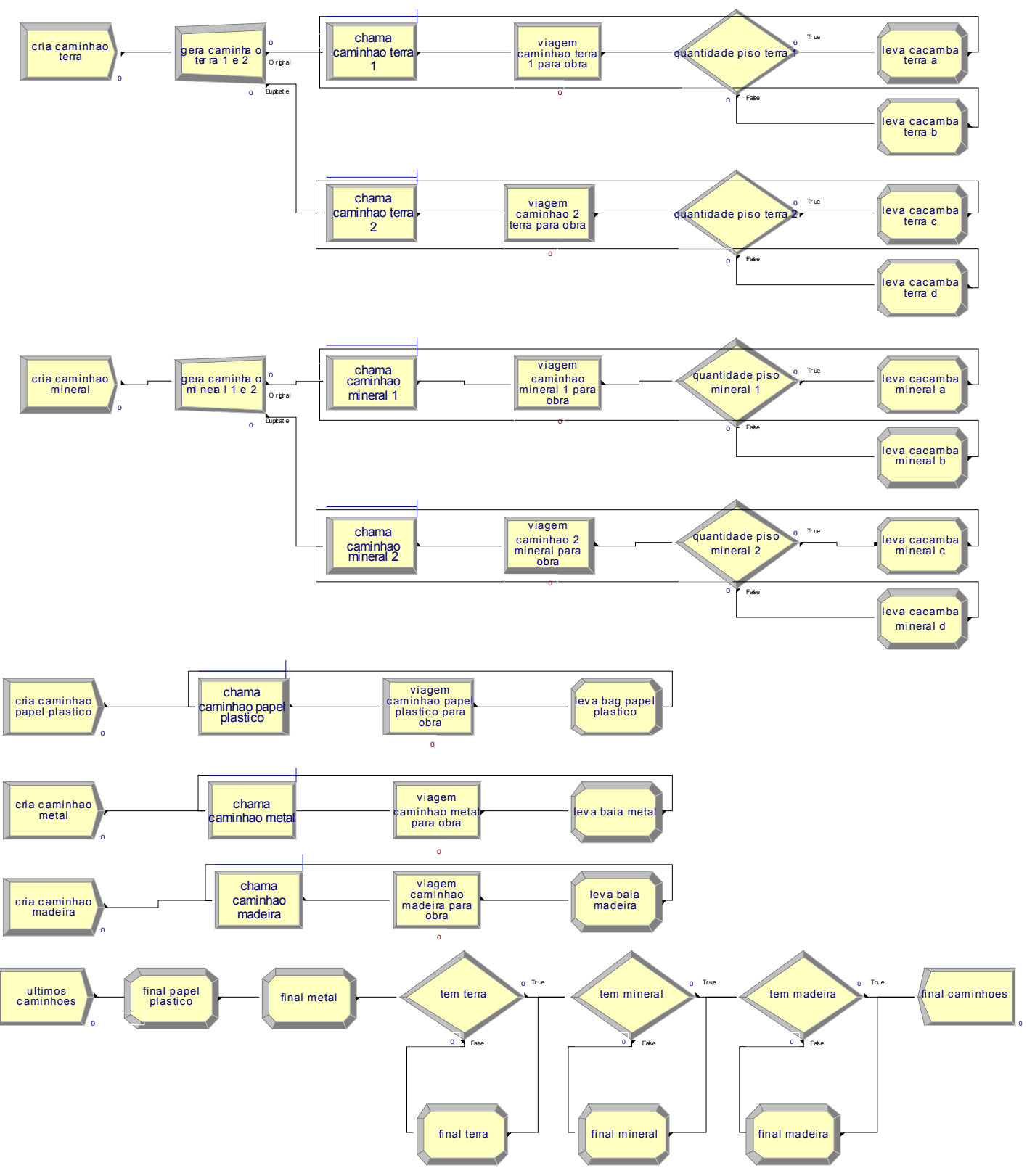

Figura 6.3. Representação da retirada de resíduos. 
- O módulo decide "quantidade piso mineral 1" tem função puramente lógica. Ele checa se a quantidade de resíduo mineral no piso excede 4.000 litros. Isso porque a lógica para os dois próximos módulos varia conforme essa informação. Se a quantidade for menor que 4000, encaminha o caminhão para o módulo assign "leva cacamba mineral a", senão a entidade é encaminhada para o módulo assign "leva cacamba mineral b";

- Os módulos assign "leva cacamba mineral a" e "leva cacamba mineral b" tem função semelhante. Ambos representam a retirada da caçamba cheia, a colocação de uma vazia e a transferência do resíduo acumulado no piso para a caçamba vazia. Além disso, funcionam como contador do número de caçambas retiradas da obra e também do custo dessas caçambas. A diferença desses dois módulos está apenas no que se refere à quantidade de resíduo no piso. No "leva cacamba mineral a" (quantidade no piso inferior ou igual a 4000) todo o resíduo do piso é colocado na caçamba nova. No "leva cacamba mineral b" (quantidade no piso maior que 4000), é colocada a quantidade de 4000 na caçamba e esse valor descontado da quantidade do piso, sendo que o restante deverá aguardar nova caçamba. O encaminhamento da entidade em ambos módulos é retorná-la para o hold "chama caminhao mineral 1", onde aguarda novamente o sinal de caçamba 1 mineral cheia para recomeçar o processo.

- O módulo hold "chama caminhao mineral 2" serve a mesma lógica acima para o segundo caminhão, que é acionado quando a caçamba mineral 2 está também cheia. A lógica dos módulos subseqüentes também segue a mesma explicação anterior, porém sempre para a caçamba mineral 2.

Para a modelagem da retirada do plástico e do papel, segue a explicação da lógica:

- O módulo create "cria caminhao papel plastico" tem função lógica de criar apenas uma entidade, no caso o caminhão que retira o papel e o plástico da obra, e o encaminha para o próximo módulo; 
- O módulo hold "chama caminhao papel plastico" representa a chamada do caminhão para a obra, que só acontece quando dois bags estão cheios, independente se são de papel ou plástico;

- O módulo process "viagem caminhao papel plastico para obra" representa o tempo de atendimento entre a ligação telefônica e a chegada do caminhão na obra. Como anteriormente, esse período foi considerado uma distribuição normal de média oito horas (que no modelo representa um dia) com desvio padrão de uma hora;

- O modelo assign "leva bag papel plastico" representa a retirada desses resíduos da obra, zerando dessa forma as quantidades desses resíduos no térreo. Após a passagem por esse módulo, o caminhão retorna para o módulo "chama caminhao papel plastico" para aguardar ser chamado novamente.

Os modelos de retirada de metal e madeira obedecem à mesma lógica do papel e plástico, portanto não serão detalhados. A diferença entre eles é que o caminhão é acionado quando a baia de metal atinge $75 \%$ e, no caso da madeira, quando atinge $50 \%$, e que a retirada da madeira é cobrada em $R \$ 75,00$ a cada $4 \mathrm{~m}^{3}$.

\subsubsection{Sistema de Contadores}

Foi utilizado um sistema de contadores para marcar em qual dia da obra está a simulação, bem como verificar, para todos os resíduos, se houve acúmulo no piso de um dia para outro. Graficamente esses contadores ficaram da seguinte forma: 


\section{CONTADORES}

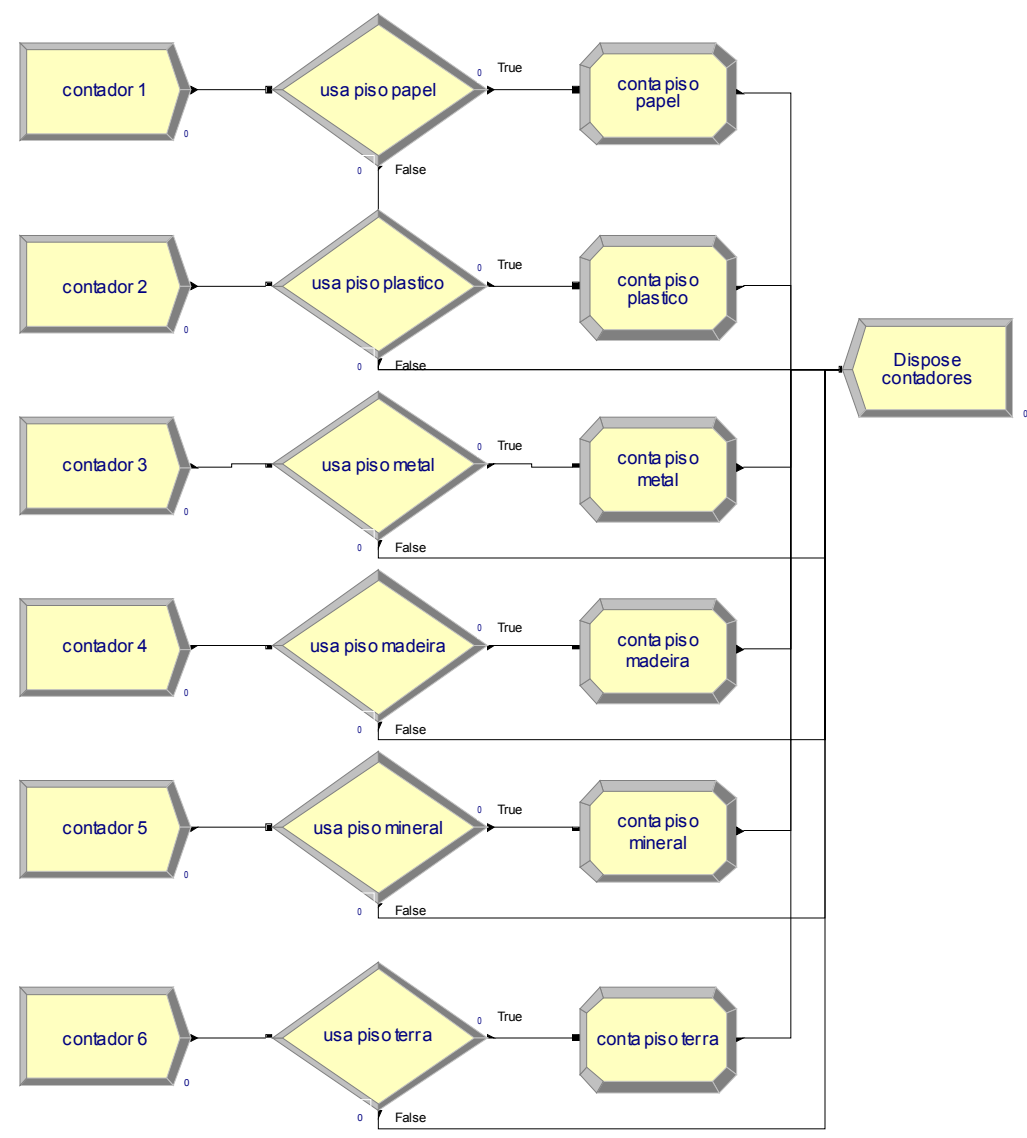

Figura 6.4. Representação dos contadores.

Como têm funcionamento idêntico para todos os resíduos, será explicada a lógica do contador referente ao papel:

- O módulo create "contador 1" gera uma entidade, nesse caso dia, a cada oito horas sempre no início do dia, lembrando que no modelo o dia possui 8 horas e não 24, já que trata de horas trabalhadas; 
- O módulo decide "usa piso papel" checa se existe resíduo de papel no piso. Caso exista, encaminha a entidade para o assign "conta piso papel". Caso contrário, a entidade segue para o módulo dispose "dispose contadores";

- O módulo assign "conta piso papel" funciona como contador, adicionando uma unidade ao valor de dias em que, no seu início, havia resíduo de papel depositado no chão;

- O módulo dispose "dispose contadores" tem apenas função lógica de retirar a entidade da simulação.

Especialmente no contador 1 há também a contagem de dias de obra, através da contagem das entidades, que são geradas a cada 8 horas.

\subsubsection{Gravadores de dados read write}

Os gravadores read write são utilizados para exportar dados da simulação para serem utilizados em outro programa. No nosso caso, esse recurso é utilizado para exportar dados para o Notepad, que depois serão utilizados no Excel. Os dados exportados são a geração total de cada resíduo por dia, o andar em que a grua atinge sua capacidade máxima, a quantidade de caçambas e o uso do piso para os resíduos de madeira, mineral e terra. Esses dados são importantes, pois permitem acompanhar a evolução do modelo diariamente (no nosso caso), e permitirão dois tipos de análise. A primeira é acompanhar a geração dos resíduos e compará-la com a geração da aplicação em um caso, podendo assim acompanhar a evolução desses números, não só o valor final. A segunda é propor alternativas de transporte de resíduos dentro e fora da obra, dependendo de como evolui o uso da grua e as saídas de caçambas. Para esse caso, só foram exportados os valores relativos à madeira, mineral e terra, pois são eles que geram custos. Os gravadores read write ficaram representados como mostrado na Figura 6.6: 


\section{READ WRITE}

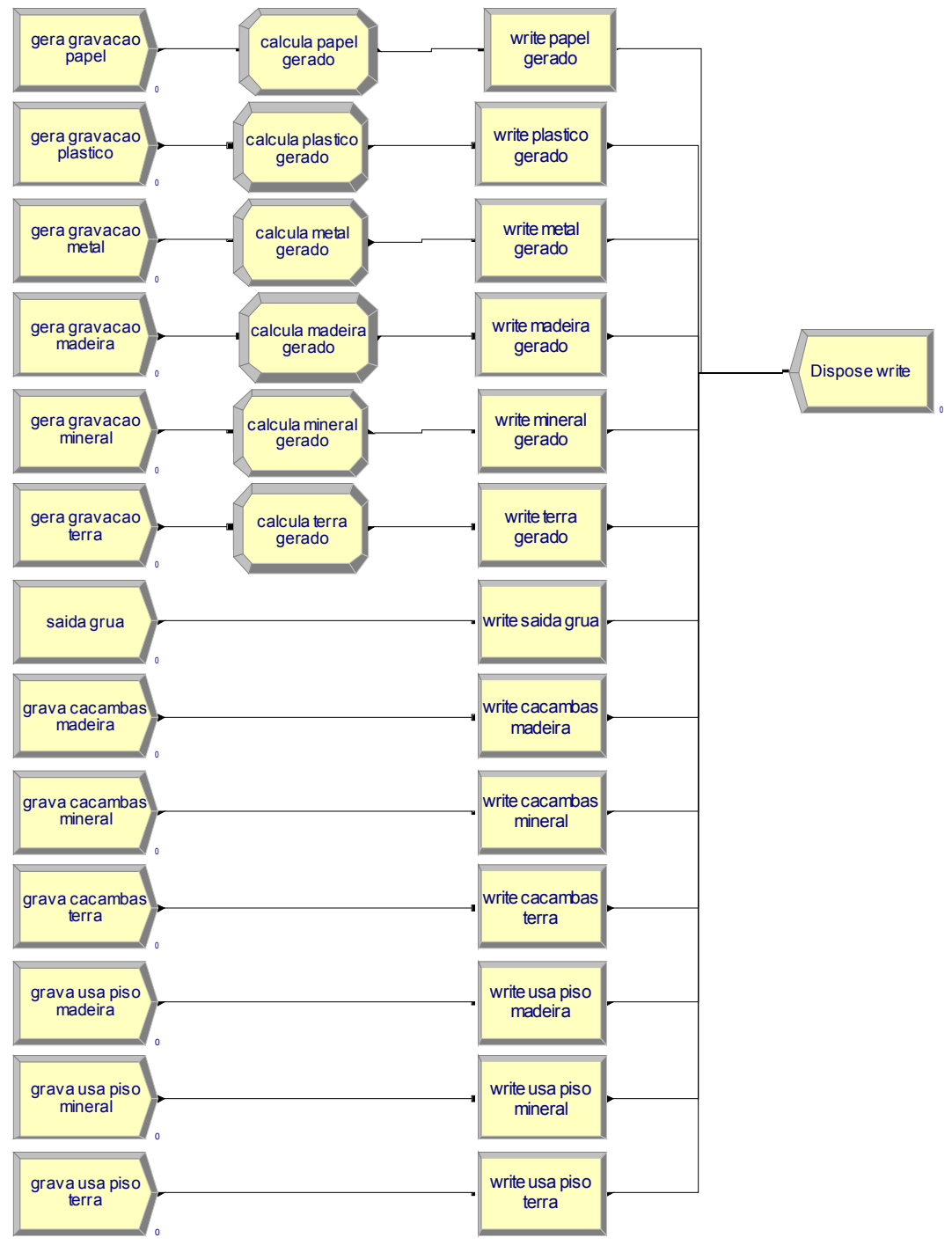

Figura 6.5. Representação dos gravadores read write.

Todos têm funcionamento semelhante, porém para gravar a geração dos resíduos, que são somados de diversos pontos (caçambas, piso, etc), foi necessário o uso de um módulo assign que criasse uma variável para assumir o valor dessa soma. Assim, será explicada a lógica do contador referente ao papel:

- O módulo create "grava geração papel" gera uma entidade, a cada oito horas sempre no início do dia, lembrando que no modelo o dia possui 8 horas e não 24 , já que trata de horas trabalhadas; 
- O módulo assign "calcula papel gerado" soma os diferentes valores que representam o total de papel gerado até o momento;

- O módulo read write "write papel gerado" exporta o valor da variável acima para um arquivo pré-determinado, no nosso caso chamado papel_gerado.txt;

- O módulo dispose "dispose write" tem apenas função lógica de retirar a entidade da simulação.

\subsubsection{Visualizadores Intermediários}

Esses visualizadores foram utilizados para acompanharmos, durante a execução do programa, a evolução e o resultado final dos indicadores dos resíduos. Segue a visualização no programa, na Figura 6.7:
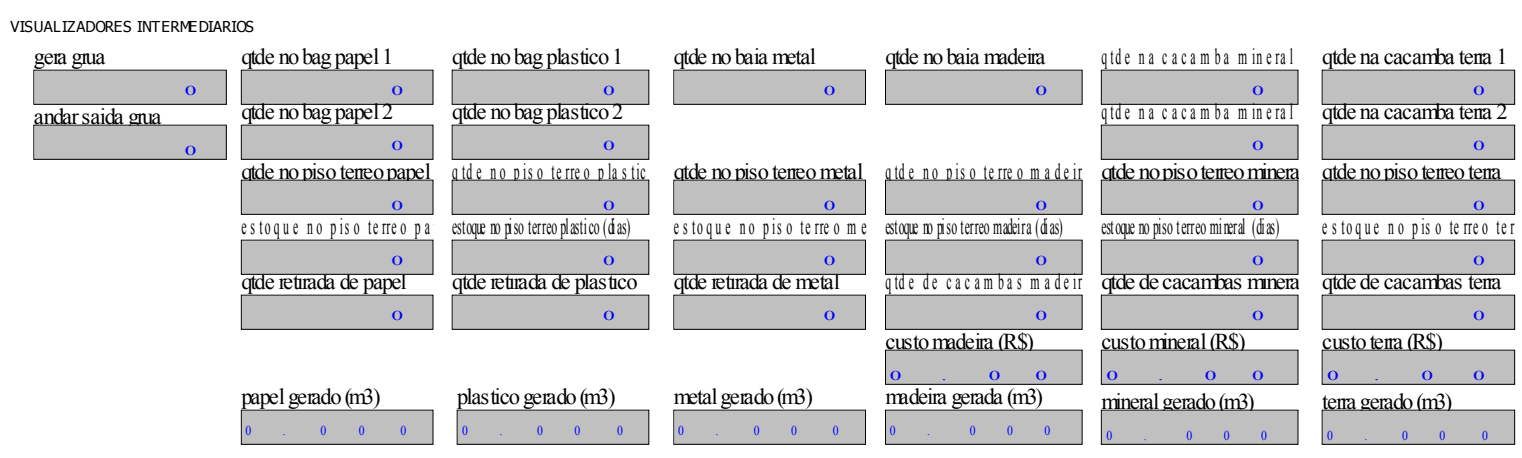

Figura 6.6. Visualizadores Intermediários.

Com esses visualizadores, podemos conferir a saída da grua ao fim do dia e em que andar ela saiu para descarregar no térreo.

Da mesma forma, podemos verificar, para cada resíduo:

- Quantidade armazenada no dispositivo de retirada de resíduo da obra;

- Quantidade armazenada no piso térreo; 
- Quantos dias, durante o andamento da obra, esse estoque de resíduo no piso do andar térreo passou de um dia para outro;

- Quantidade de resíduo retirado da obra;

- Custo da retirada, quando esse custo existir;

- Volume gerado de cada resíduo, em metros cúbicos.

\subsubsection{Visualizadores Finais}

Os visualizadores finais tratam do andamento da obra e da geração de resíduo como um todo. Esses visualizadores são:

VISUALIZA DO RES FINAIS

dias de obra residuo total gerado $(\mathrm{m} 3)$

\begin{tabular}{|c|c|c|}
\hline & & $\mathrm{O}$ \\
\hline \multicolumn{3}{|c|}{ custo total $(\mathrm{R} \$)$} \\
\hline O & 0 & 0 \\
\hline
\end{tabular}

$\begin{array}{llll}0 & 0 & 0 & 0\end{array}$
residuo por area $(\mathrm{m} 3 / \mathrm{m} 2)$

$0 \quad 0 \quad 0 \quad 0$

residuo por area $(\mathrm{kg} / \mathrm{m} 2)$

O - O

Figura 6.7. Visualizadores finais.

Com esses visualizadores, podemos acompanhar:

- Quantos dias de obra já se passaram;

- Qual o custo total da remoção dos resíduos; 
- Quantidade de resíduo gerado na obra, em metros cúbicos;

- Taxa de geração de volume de resíduo por metro quadrado de obra;

- Taxa de geração de massa de resíduo por metro quadrado de obra;

\subsection{CONCLUSÃO DO CAPÍTULO}

Foi construído, com o programa Arena 7.0, o modelo que deve simular a geração de resíduos do Edifício Piloto. Esse modelo será inicialmente validado para depois cumprir seu objetivo, que é verificar os impactos de diversos cenários, que serão apresentados no próximo Capítulo.

É importante frisar novamente que, como em todo modelo de simulação, este não irá apresentar a solução ótima, já que não gera novas soluções. Os valores que serão apresentados são o resultado dos diferentes cenários, sendo eles melhores ou piores que a solução inicial, representada na aplicação em um caso. 


\section{CAPÍTULO 7. SIMULAÇÕES DO EDIFÍCIO PILOTO}

\subsection{INTRODUÇÃO}

Com o modelo desenhado em Arena concluído, serão feitas algumas simulações do Edifício Piloto com diferentes dados de entrada, para simular diferentes cenários. Essas simulações terão três objetivos.

Inicialmente, foi feita a simulação com os mesmos dados da aplicação no Edifício Piloto. O objetivo é verificar se o modelo representa de forma satisfatória a realidade, podendo assim ser validado e utilizado em outros cenários. Esses resultados não precisam ser necessariamente idênticos já que, como citado anteriormente, no modelo a geração de resíduos está obedecendo a uma função exponencial, que apresenta dessa forma desvio. Apesar disso, o resultado deve ser muito próximo, então consideramos um desvio máximo de 2,5\% para validar o modelo. Além de avaliar o resultado final, será verificada a evolução da geração dos resíduos no decorrer do tempo, para compará-los com a geração da aplicação em um caso. O objetivo dessa comparação é validar o "ritmo" de geração de resíduos do modelo, para podermos propor melhorias na logística de retirada de resíduos da obra.

O próximo objetivo foi verificar se efetivamente existe melhora com o Plano de Gestão de Resíduos aplicado na íntegra. Como o Plano tem a função de reduzir a geração de resíduos e em seguida segregá-los, serão verificadas as possíveis combinações entre essas duas fases, para verificar o impacto de cada uma. Assim, serão verificados os seguintes cenários: sem redução nem segregação; com redução e sem segregação; e sem redução, porém com segregação. As variáveis apresentadas nos visualizadores finais (resíduo total gerado, custo total e resíduo em volume e em massa por área) foram comparadas para fazer essa avaliação.

O último objetivo é propor um novo modelo de logística de retirada dos resíduos para fora da obra. 
A retirada dos resíduos (em especial a terra, o mineral e a madeira, que geram custos) acontecia quando a empresa transportadora era chamada pela obra. Será estudada a freqüência dessas retiradas, com o objetivo de negociar os valores por caçamba. A motivação é que, quando a empresa de transporte tem dias previamente combinados para retirar os resíduos (ao invés de ficar disponível para ser chamada a qualquer momento), ela pode programar o uso mais eficiente de seus recursos, podendo assim reduzir o valor cobrado da Construtora. Para esse estudo, é importante que a geração desses resíduos durante a simulação reflita o que de fato ocorre na obra, como será verificado na primeira simulação.

\subsection{SIMULAÇÃO 1: VERIFICAÇÃO DA SIMULAÇÃO COM DADOS DA APLICAÇÃO EM UM CASO}

O objetivo dessa primeira simulação é, na verdade, verificar se a construção do modelo foi feita de forma a representar a realidade. Assim, a simulação será feita com os dados reais da aplicação em um caso, e o modelo deve dessa forma apresentar resultados muito próximos:

Tabela 7.1. Dados de entrada para verificação.

\begin{tabular}{c|cc} 
& $\begin{array}{c}\text { EDIFÍCIO PILOTO } \\
\text { Quantidade }\end{array}$ & Unidade \\
\hline Resíduos & 38,5 & $\mathrm{~m}^{3}$ \\
Papel & 34,7 & $\mathrm{~m}^{3}$ \\
Plástico & 2,7 & $\mathrm{~m}^{3}$ \\
Metal & 308,0 & $\mathrm{~m}^{3}$ \\
Madeira & 248,0 & $\mathrm{~m}^{3}$ \\
Terra & 328,0 & $\mathrm{~m}^{3}$ \\
Alvenaria e concreto & $\mathbf{9 5 9 , 9}$ & $\mathrm{m}^{\mathbf{3}}$
\end{tabular}

Também será verificado, graficamente, a geração com resíduo com o tempo, conforme descrito anteriormente. 


\subsection{SIMULAÇÃO 2: EDíFíCIO PILOTO SEM REDUÇÃO NEM SEGREGAÇÃO DO RESÍDUO}

Esta simulação verifica o que aconteceria caso nenhum Plano houvesse sido proposto para o Edifício Piloto. Assim essa simulação servirá para avaliar o real impacto do Plano de Gestão de Resíduo. Como o modelo trabalha com volume de resíduos, o valor total de geração de resíduo será aumentado em 11,5\%, a massa considerada será de 1.200 $\mathrm{kg} / \mathrm{m}^{3}$ e o resíduo não será segregado. Os dados para modelagem são:

Tabela 7.2. Dados de entrada da Simulação 2.

\begin{tabular}{l|l}
\multicolumn{2}{c}{ EDIFÍCIO PILOTO } \\
Resíduos & Quantidade $\left(\mathrm{m}^{3}\right)$ \\
\hline Todos & 1065,43
\end{tabular}

\subsection{SIMULAÇÃO 3: EDIFÍCIO PILOTO SEM REDUÇÃO E COM SEGREGAÇÃO DO RESÍDUO}

Nesta etapa simulou-se o que ocorreria se somente houvesse a segregação do resíduo, porém sem aplicar a parte do Plano que tinha como objetivo diminuir a quantidade de resíduo gerado. Nesta simulação, foi aumentado em 11,5\% o valor individual de cada resíduo gerado. Assim, os dados são:

Tabela 7.3. Dados de entrada da Simulação 3.

\begin{tabular}{l|r}
\multicolumn{2}{c}{ EDIFÍCIO PILOTO } \\
\multicolumn{1}{c|}{ Resíduos } & Quantidade $\left(\mathrm{m}^{3}\right)$ \\
\hline Papel & 42,76 \\
Plástico & 38,48 \\
Metal & 2,95 \\
Madeira & 341,88 \\
Terra & 275,28 \\
Mineral & 364,08 \\
\hline TOTAL & $\mathbf{1 0 6 5 , 4 3}$
\end{tabular}




\subsection{SIMULAÇÃO 4: EDIFÍCIO PILOTO COM REDUÇÃO E SEM SEGREGAÇÃO DO RESÍDUO}

Neste caso simulamos o que aconteceria com o edifício Piloto caso apenas a parte do Plano que trata da redução do resíduo fosse aplicada, porém sem ocorrer segregação. Assim, foi utilizado apenas o valor total de resíduo gerado no Edifício Piloto:

Tabela 7.4. Dados de entrada da Simulação 4.

\begin{tabular}{l|l}
\multicolumn{2}{c}{ EDIFÍCIO PILOTO } \\
Resíduos & Quantidade $\left(\mathrm{m}^{3}\right)$ \\
\hline Todos & 959,85
\end{tabular}

\subsection{SIMULAÇÃO 5: NOVO MODELO DE RETIRADA DE RESÍDUOS}

Para propor esse novo modelo, é necessário estudar a geração diária dos resíduos. Como no caso em estudo os custos de transporte estão relacionados a três resíduos madeira, mineral e terra - seguem os gráficos que representam essa geração:

Gráfico 7.1. Geração diária de madeira no Modelo.

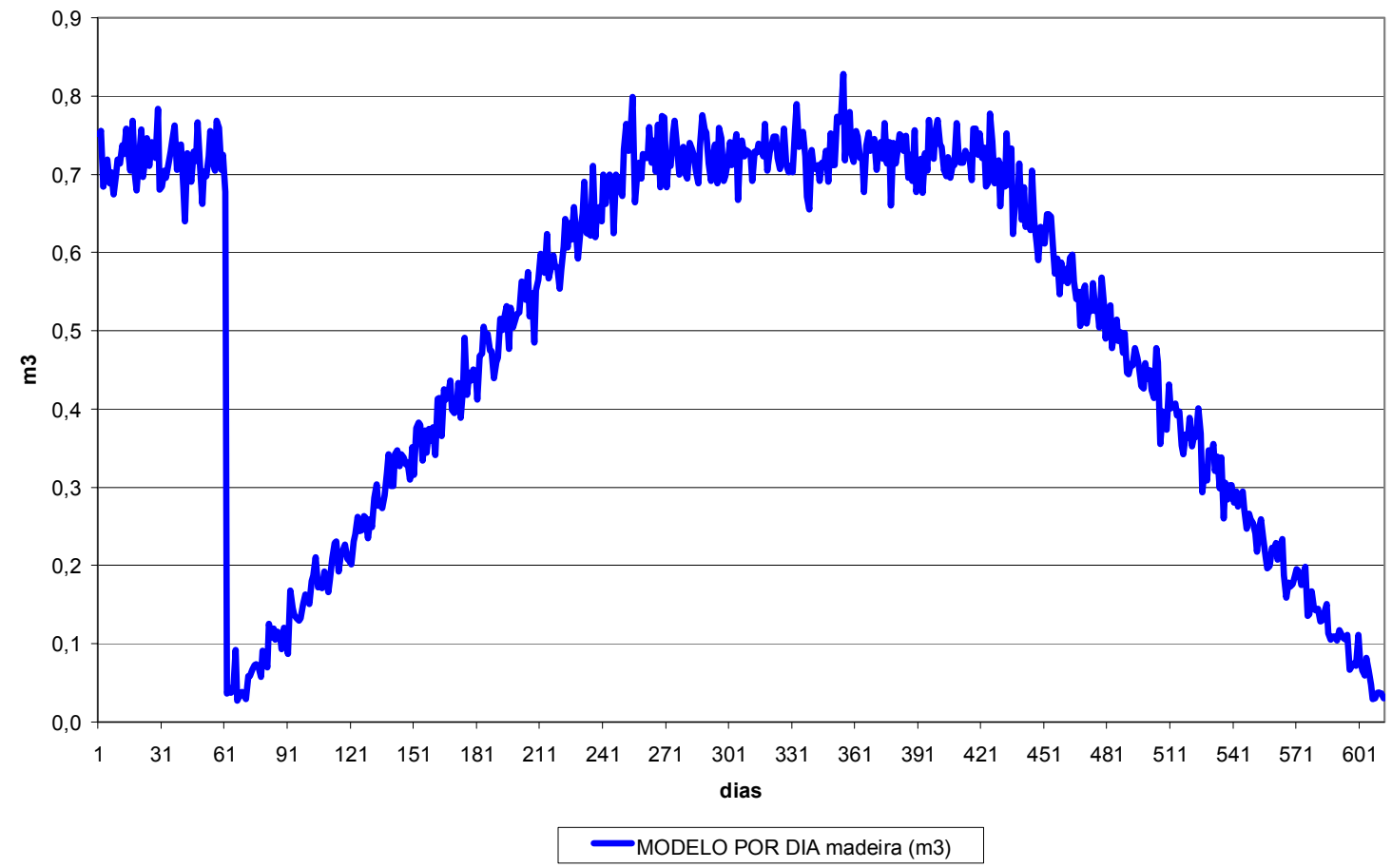


Gráfico 7.2. Geração diária de mineral no Modelo.

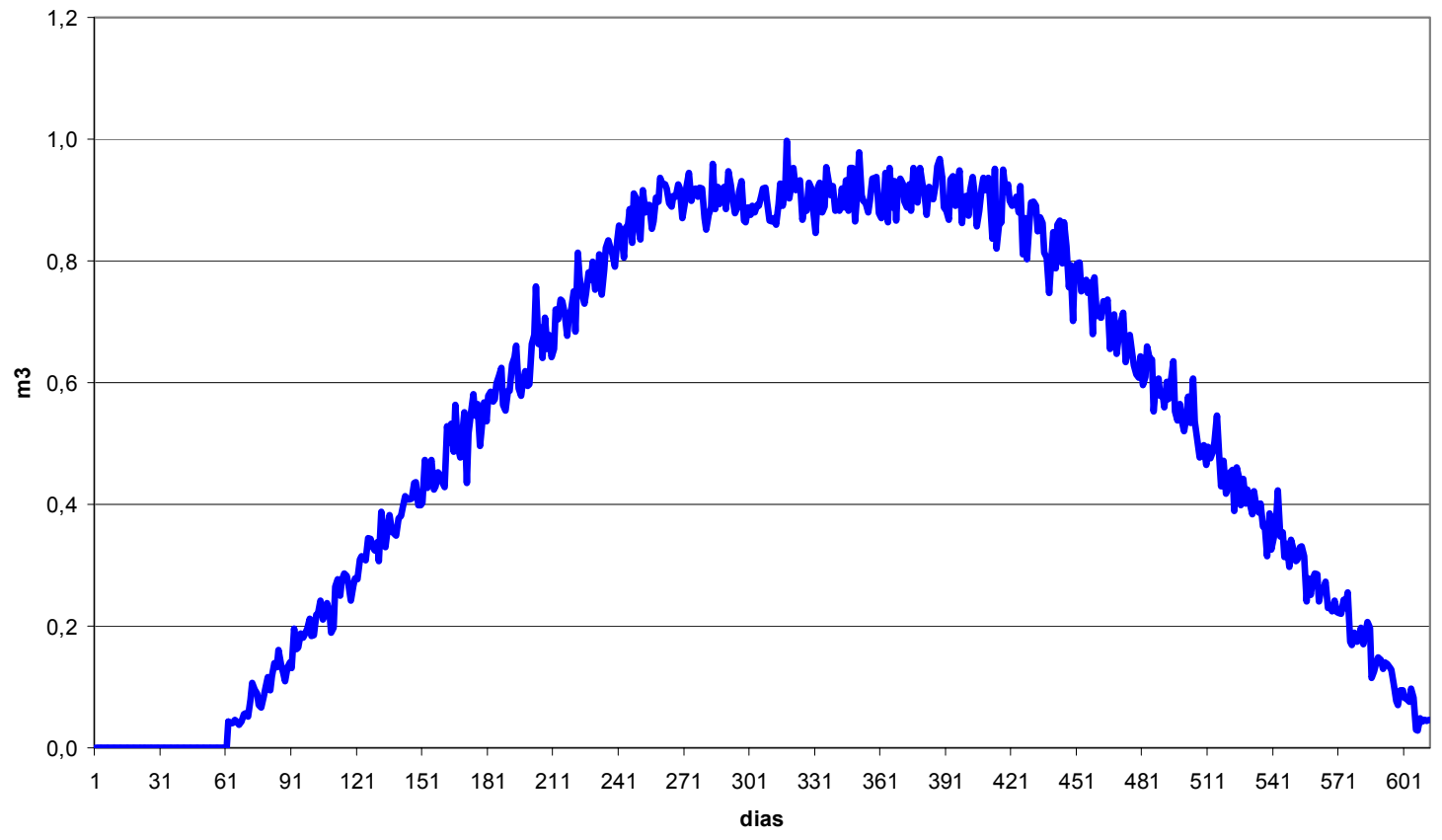

MODELO POR DIA mineral (m3)

Gráfico 7.3. Geração diária de terra no Modelo.

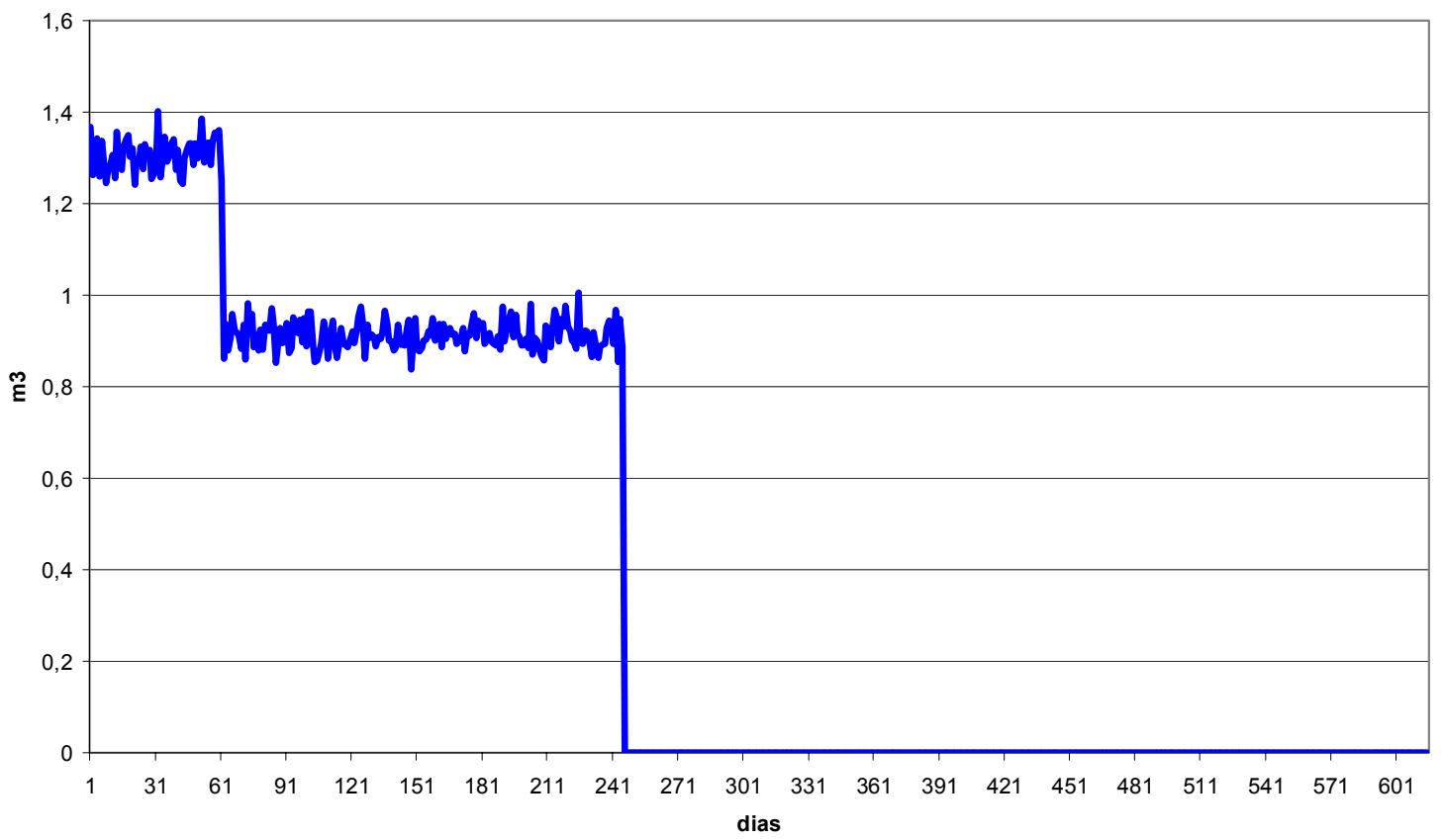

MODELO POR DIA terra (m3) 


\subsubsection{Retirada da madeira}

O resíduo de madeira possui quatro diferentes padrões de geração, conforme o Gráfico 7.1. Inicialmente, durante a preparação do terreno e fundação, a geração pode ser considerada constante com média de $0,7184 \mathrm{~m}^{3} / \mathrm{dia}$.

Gráfico 7.4. Geração diária de madeira e linha de tendências do dia 1 ao 61.

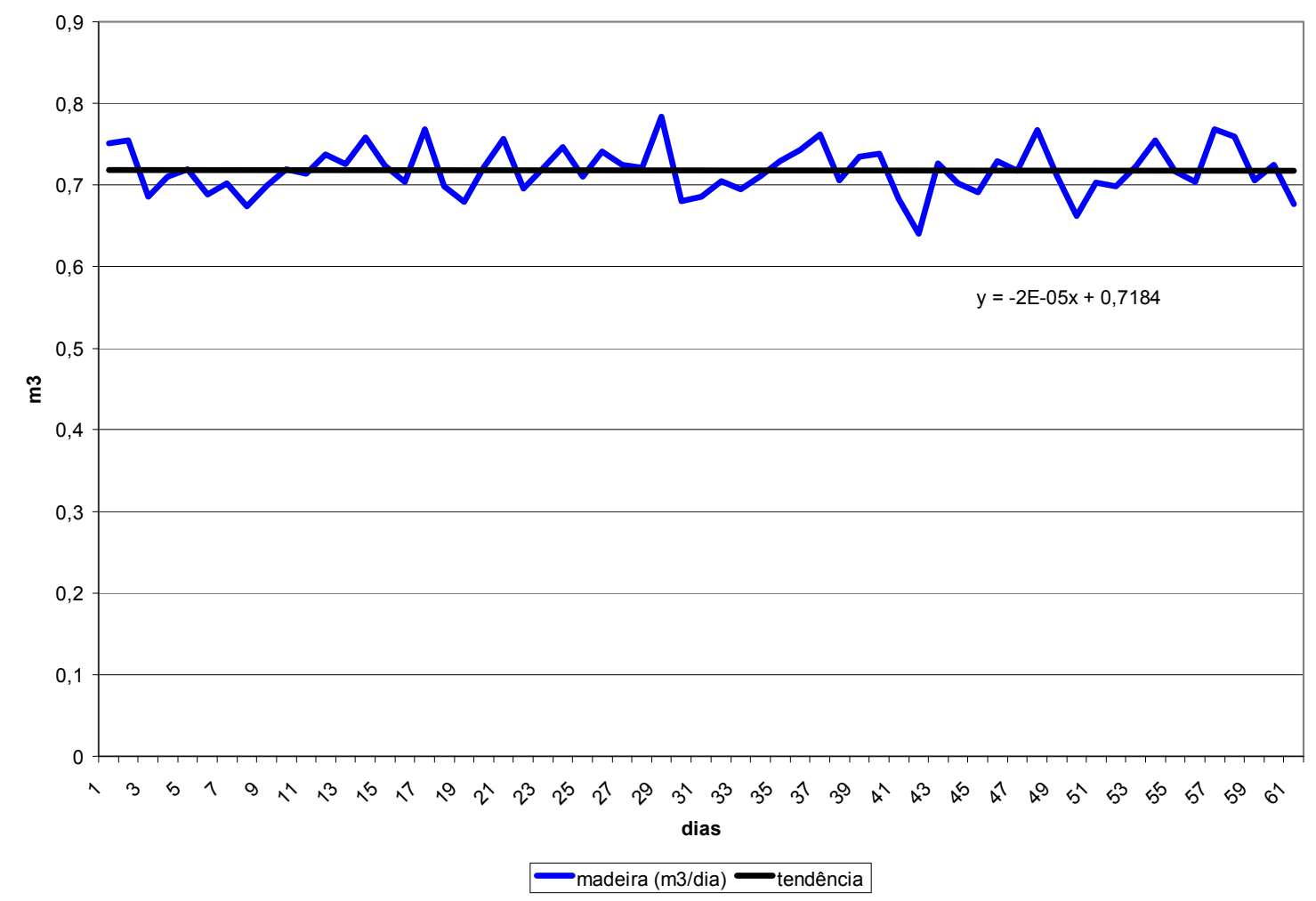

Depois, até o dia 251, quando o vigésimo pavimento é iniciado, a geração por dia aumenta de forma constante, com geração inicial de $0,0182 \mathrm{~m}^{3}$ e um incremento de $0,0036 \mathrm{~m}^{3} / \mathrm{dia}$, conforme descrito na linha de tendência do Gráfico 7.5 .

Após essa fase a geração pode ser novamente considerada constante até o dia 435, conforme demonstrado no Gráfico 7.6, quando as atividades no primeiro pavimento se encerram. Nesse período, a geração média é de $0,7293 \mathrm{~m}^{3} /$ dia. 
93

Gráfico 7.5. Geração diária de madeira e linha de tendências do dia 62 ao 251.

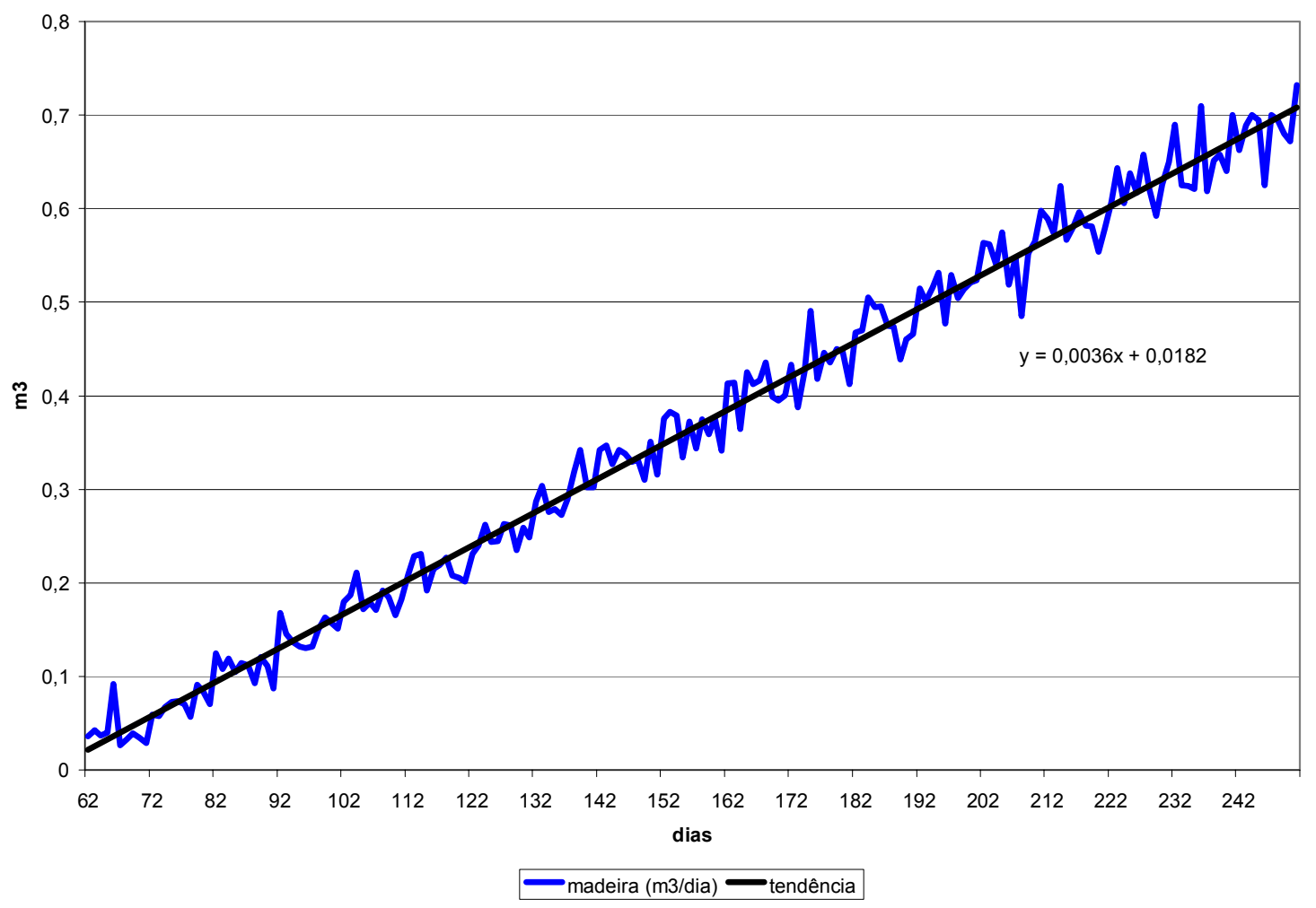

Gráfico 7.6. Geração diária de madeira e linha de tendências do dia 252 ao 435.

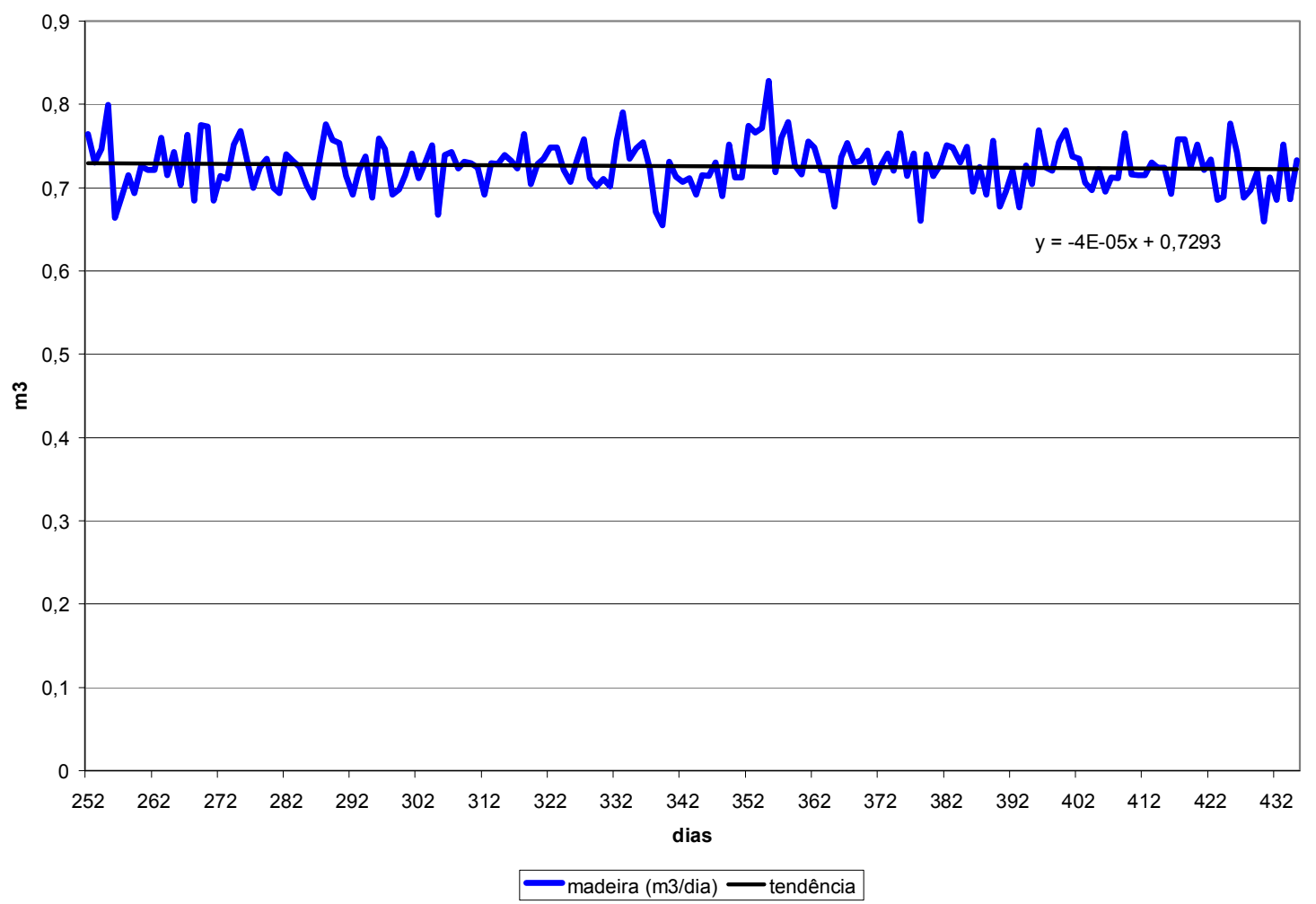


Após o encerramento do primeiro pavimento, a geração diária diminui a uma taxa de $0,0036 \mathrm{~m}^{3} / \mathrm{dia}$, até atingir o término da obra.

Gráfico 7.7. Geração diária de madeira e linha de tendências do dia 436 ao 615.

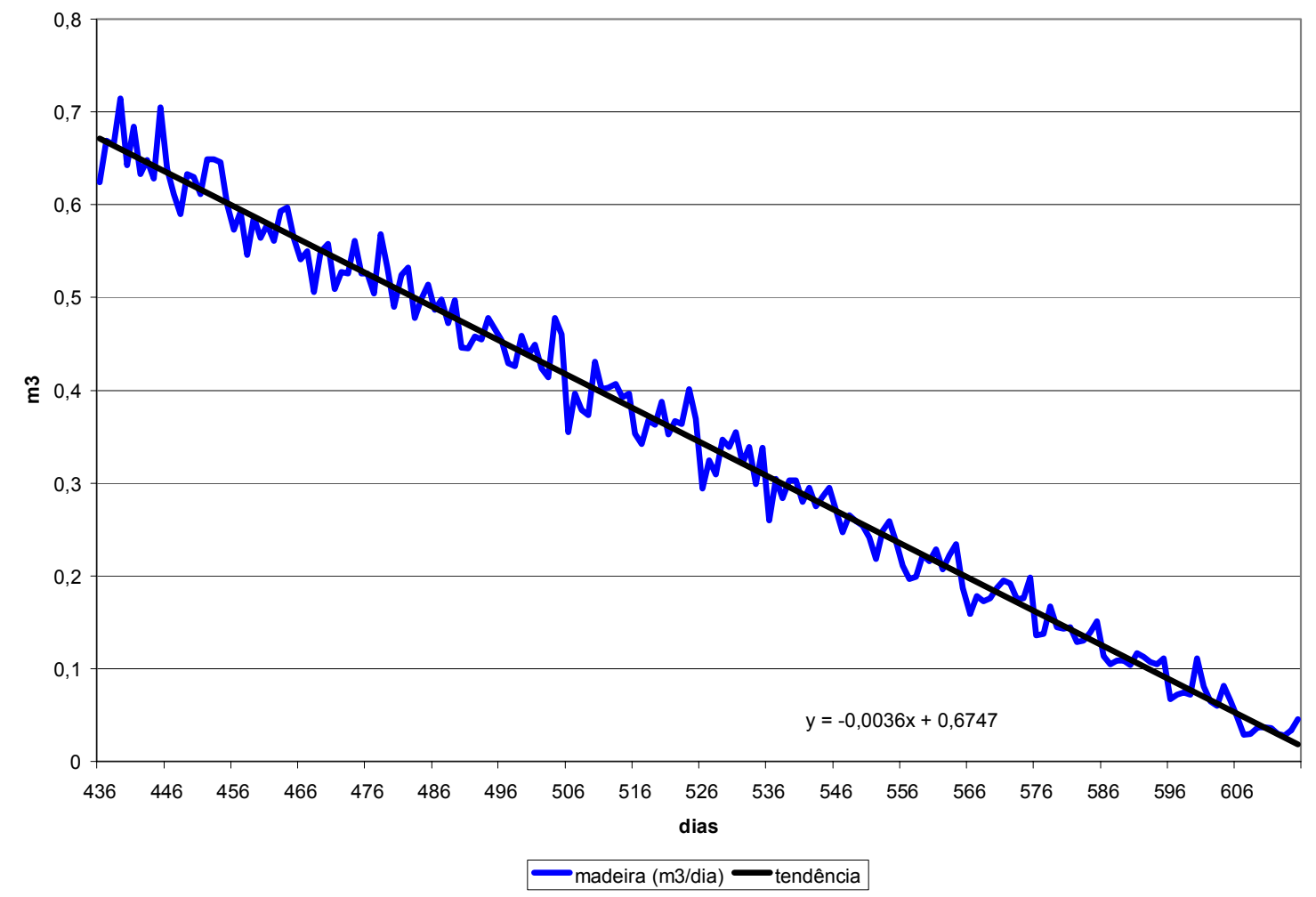

Dessa forma, será proposta uma política de retirada por fase, baseada nas tendências apresentadas por fase.

\subsubsection{Retirada do mineral}

A geração do resíduo mineral é feita em três diferentes fases, sendo que o início da geração ocorre somente no dia 61. A primeira fase a geração é crescente de forma constante, com geração inicial de $0,0234 \mathrm{~m}^{3}$ e um incremento de $0,0045 \mathrm{~m}^{3} /$ dia 
Gráfico 7.8. Geração diária de mineral e linha de tendências do dia 62 ao 251.

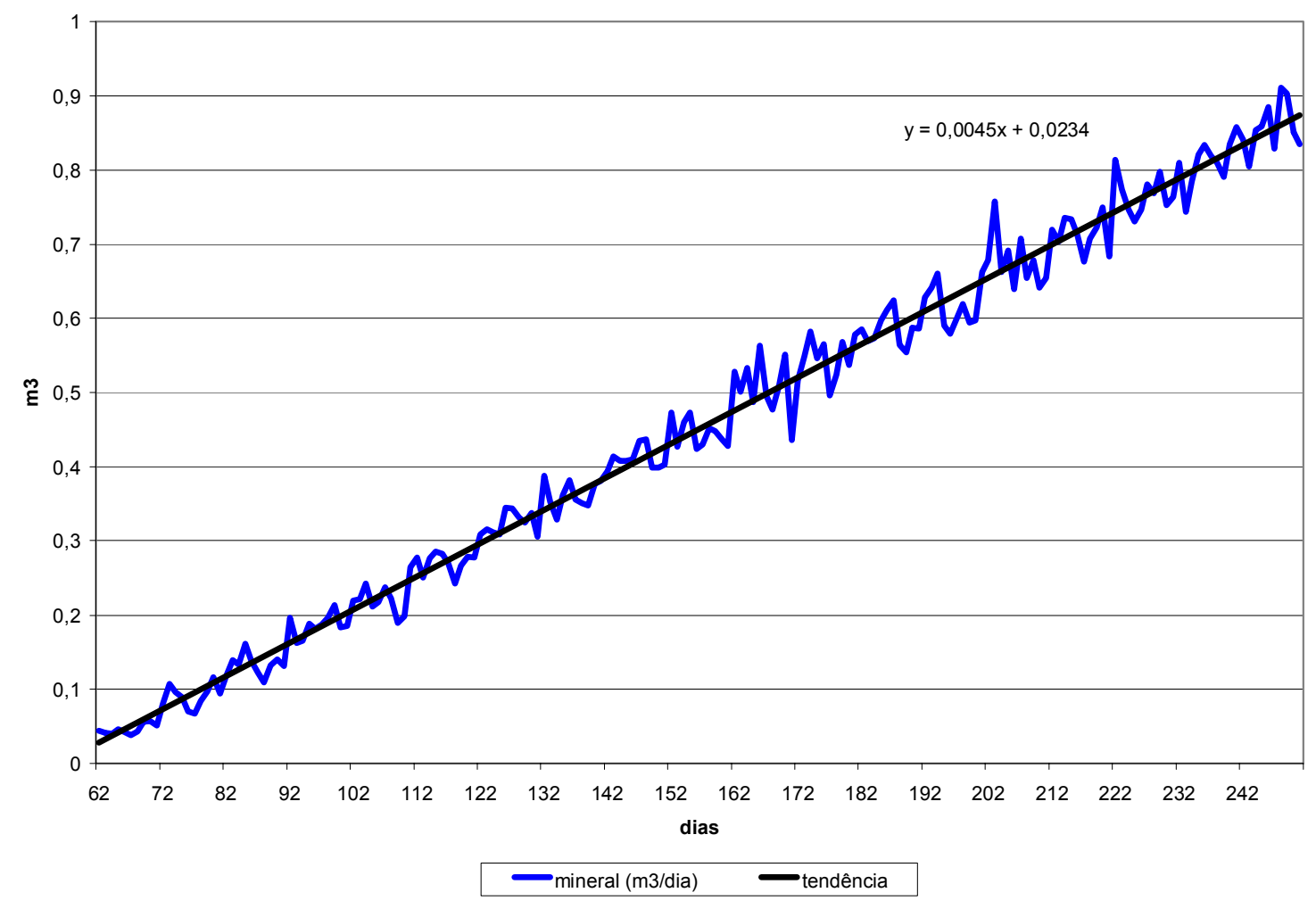

A próxima fase de geração do resíduo mineral pode ser considerada constante até o dia 435 , com a geração de $0,907 \mathrm{~m}^{3} /$ dia, como demonstrado no Gráfico 7.9 .

Com o início da conclusão dos andares, a partir do dia 436, a geração decresce de $0,907 \mathrm{~m}^{3} /$ dia para zero a uma taxa de $0,0045 \mathrm{~m}^{3} /$ dia (Gráfico 7.10 ).

Como no caso da madeira, apresentado anteriormente, será proposta uma política de retirada por fase, baseada nas tendências apresentadas em cada uma delas. 
Gráfico 7.9. Geração diária de mineral e linha de tendências do dia 252 ao 435.

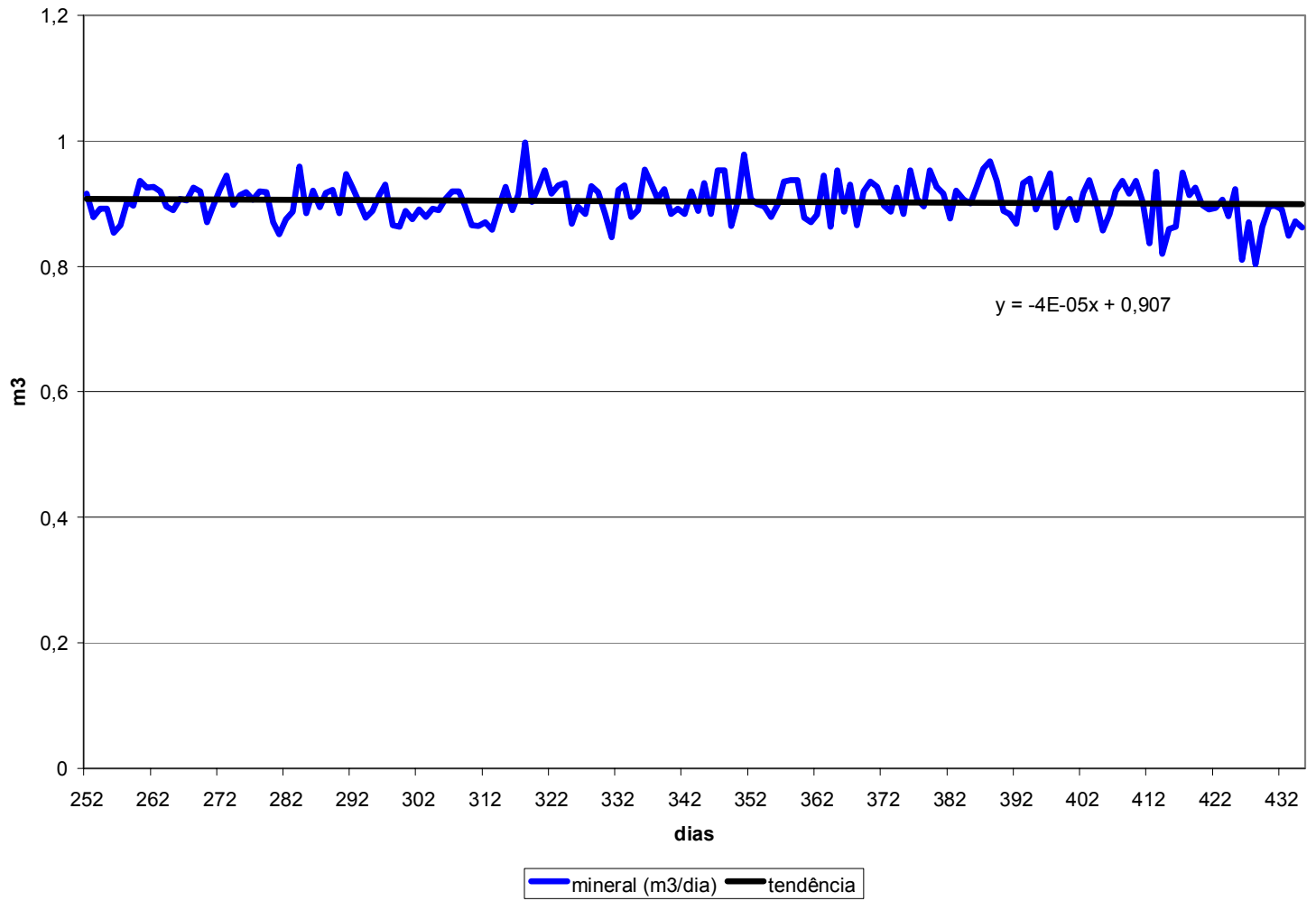

Gráfico 7.10. Geração diária de mineral e linha de tendências do dia 436 ao 615.

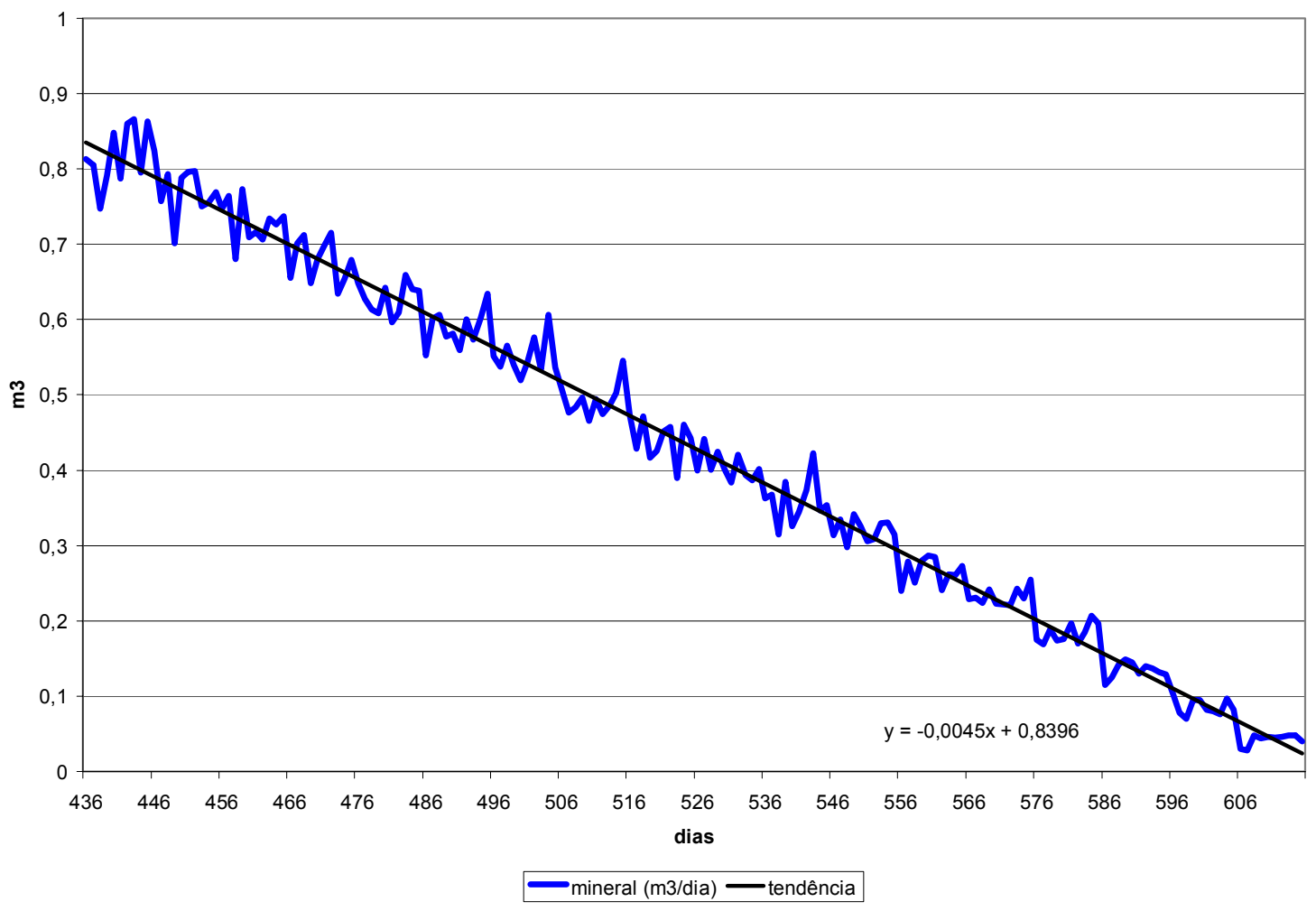




\subsubsection{Retirada da terra}

A geração da terra como resíduo é feita em duas diferentes fases. A primeira fase, até o dia 61, representa a preparação do terreno e a execução das fundações, e pode ser aproximada por uma média constante de geração de $1,2975 \mathrm{~m}^{3} /$ dia.

Gráfico 7.11. Geração diária de terra e linha de tendências do dia 1 ao 61.

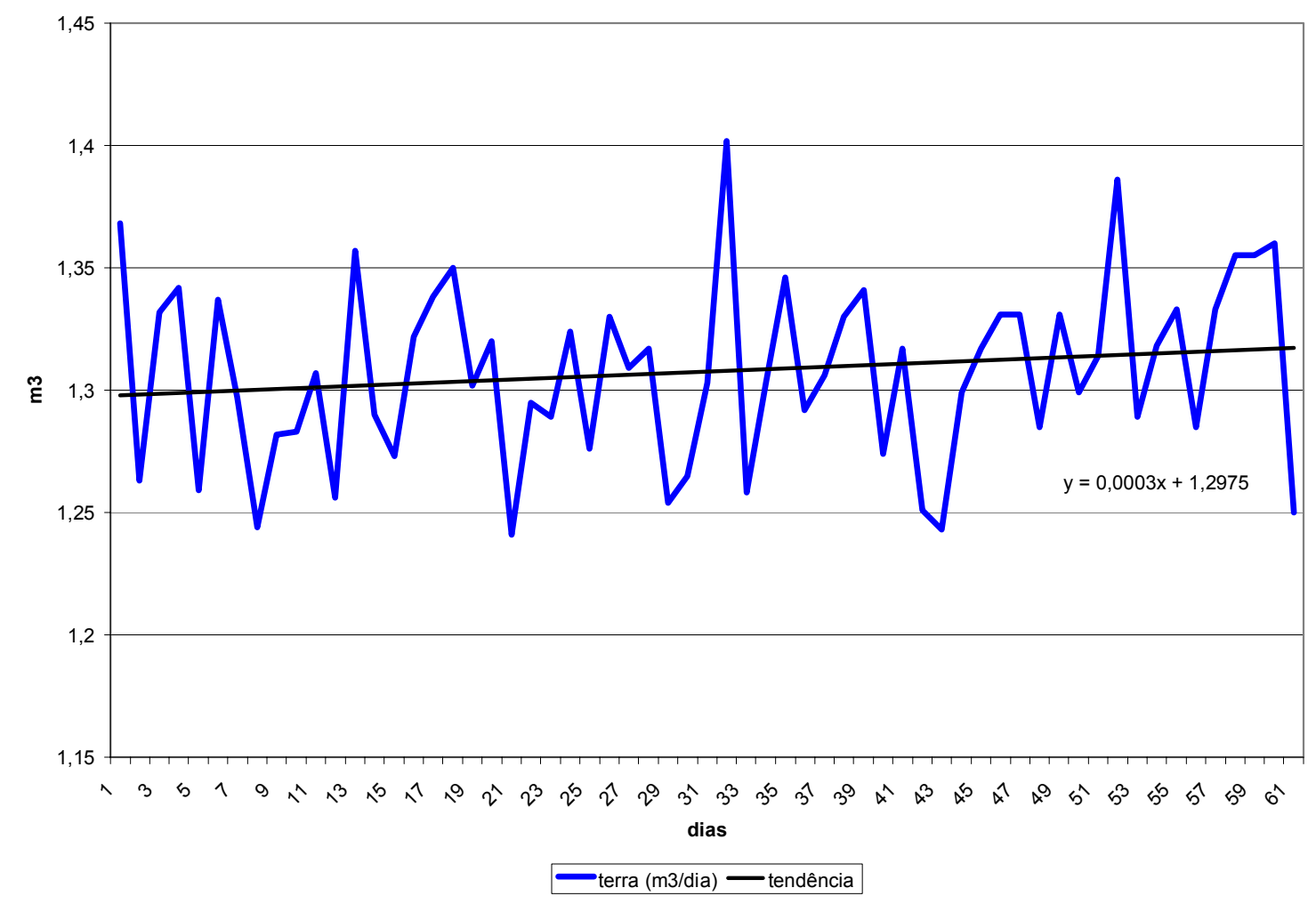

A segunda fase ocorre do dia 62 ao 245, quando encerra a retirada de terra da escavação dos subsolos. Nessa fase, a geração também pode ser considerada constante, com média de $0,9117 \mathrm{~m}^{3} /$ dia.

Como no caso dos outros resíduo, essas informações serão utilizadas para planejar uma política de retirada de terra para cada fase. 
Gráfico 7.12. Geração diária de terra e linha de tendências do dia 62 ao 245.

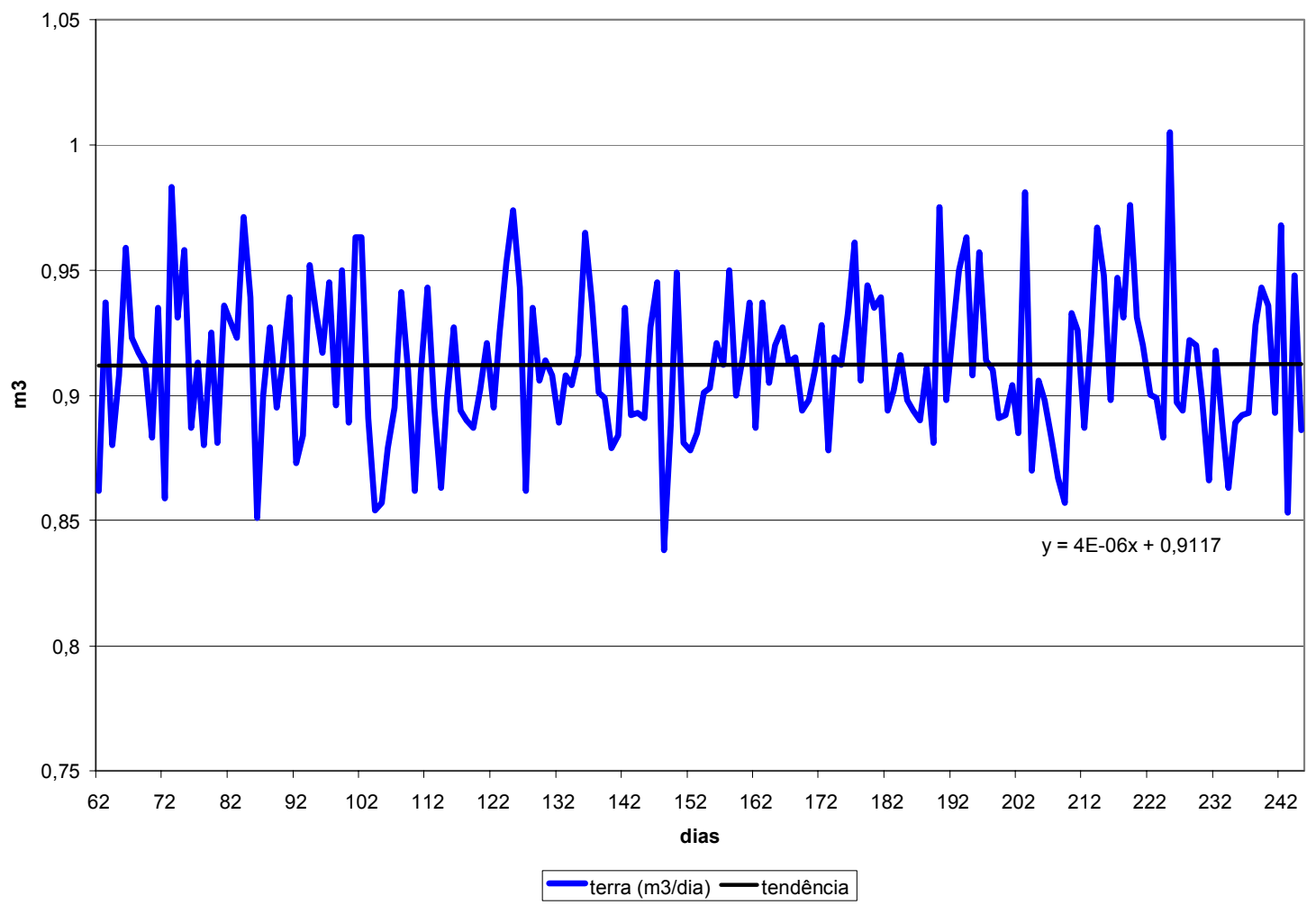




\subsection{RESULTADO DAS SIMULAÇÕES DA EFETIVIDADE DO PLANO DE GESTÃO}

Dessa forma, analisando todos esses cenários, conseguiremos avaliar de forma mais clara qual o impacto do Plano de Gestão de Resíduos nas obras. Abaixo, segue a planilha de verificação do modelo (Simulação 1), que comprova que ele retrata o caso real com bastante precisão:

Tabela 7.5. Resultado da verificação do modelo.

\begin{tabular}{l|c|c|c} 
& $\begin{array}{c}\text { ESTUDO DE } \\
\text { CASO }\end{array}$ & $\begin{array}{c}\text { VERIFICAÇÃO } \\
\text { DO MODELO }\end{array}$ & VARIAÇÃO \\
\hline Redução & $\operatorname{sim}$ & $\operatorname{sim}$ & \\
Segregação & $\operatorname{sim}$ & $\operatorname{sim}$ & \\
Resíduo total $\left(\mathrm{m}^{3}\right)$ & 959,850 & 960,969 & $0,1 \%$ \\
Custo total $(\mathrm{R} \$)$ & $\mathrm{R} \$ 18.735,00$ & $\mathrm{R} \$ 19.170,00$ & $2,3 \%$ \\
Taxa de geração $\left(\mathrm{m}^{3} / \mathrm{m}^{2}\right)$ & 0,176 & 0,176 & $0,0 \%$ \\
Taxa de geração $\left(\mathrm{kg} / \mathrm{m}^{2}\right)$ & 156,7 & 156,9 & $0,1 \%$
\end{tabular}

Seguem também os gráficos de geração de resíduos no decorrer da obra. Para avaliar se eles correspondem com a realidade, para cada resíduo existe também a geração real durante a obra.

Essa geração durante a obra foi calculada através da saída mensal de resíduos, sendo que esse valor foi distribuído igualmente dentro dos dias de cada respectivo mês. 
Gráfico 7.13. Geração acumulada de papel Real X Modelo.

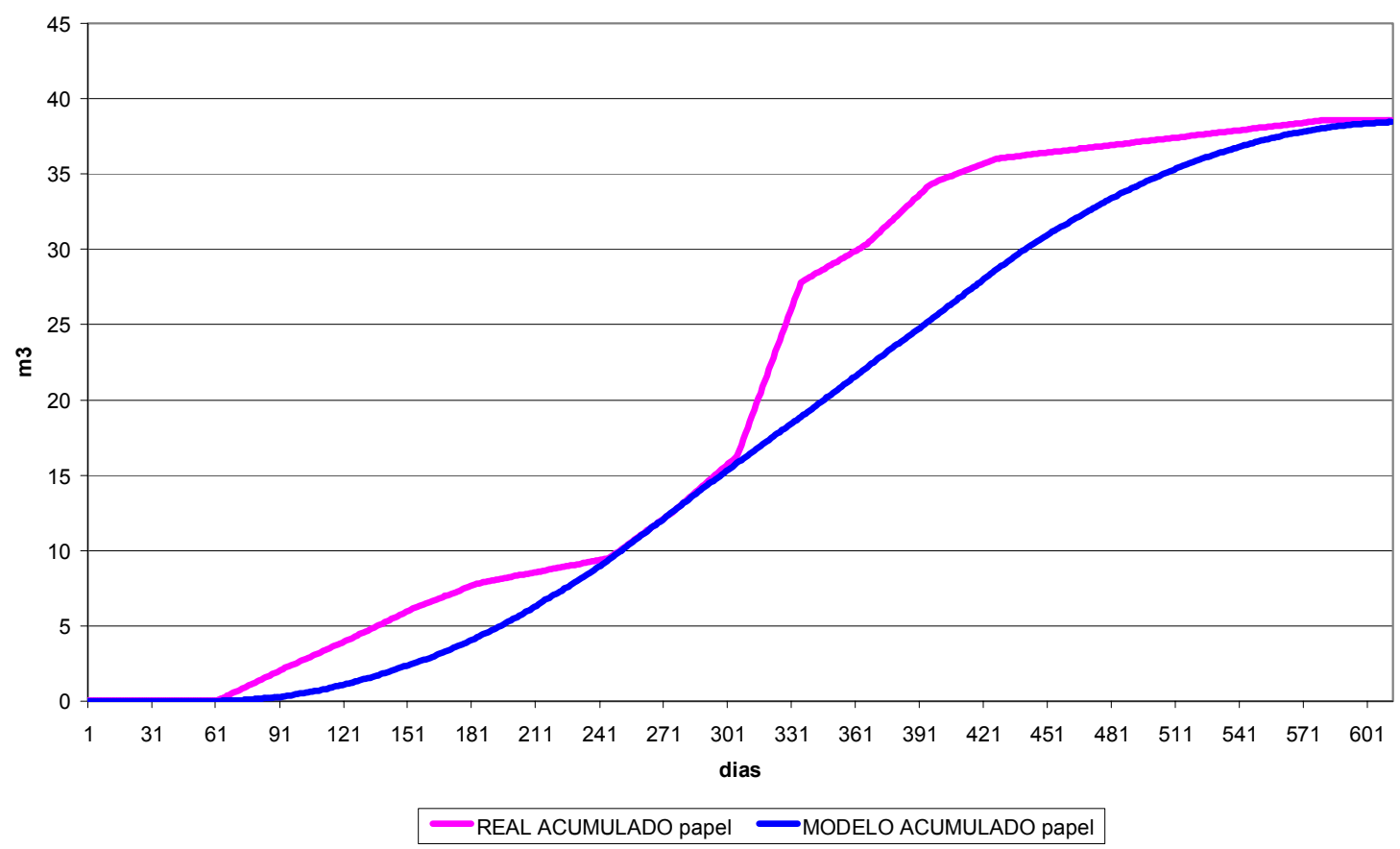

Gráfico 7.14. Geração acumulada de plástico Real X Modelo.

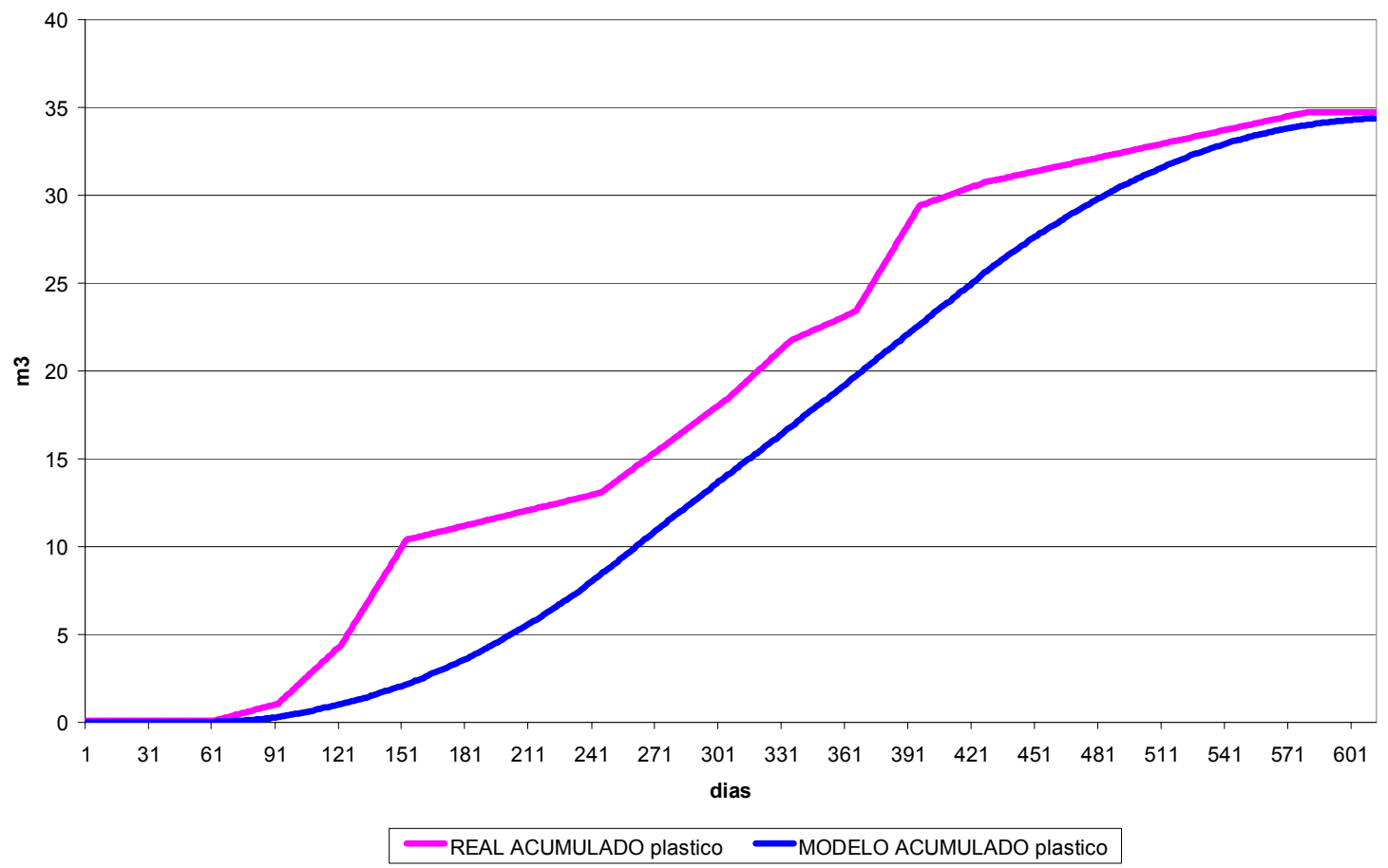


Gráfico 7.15. Geração acumulada de metal Real X Modelo.

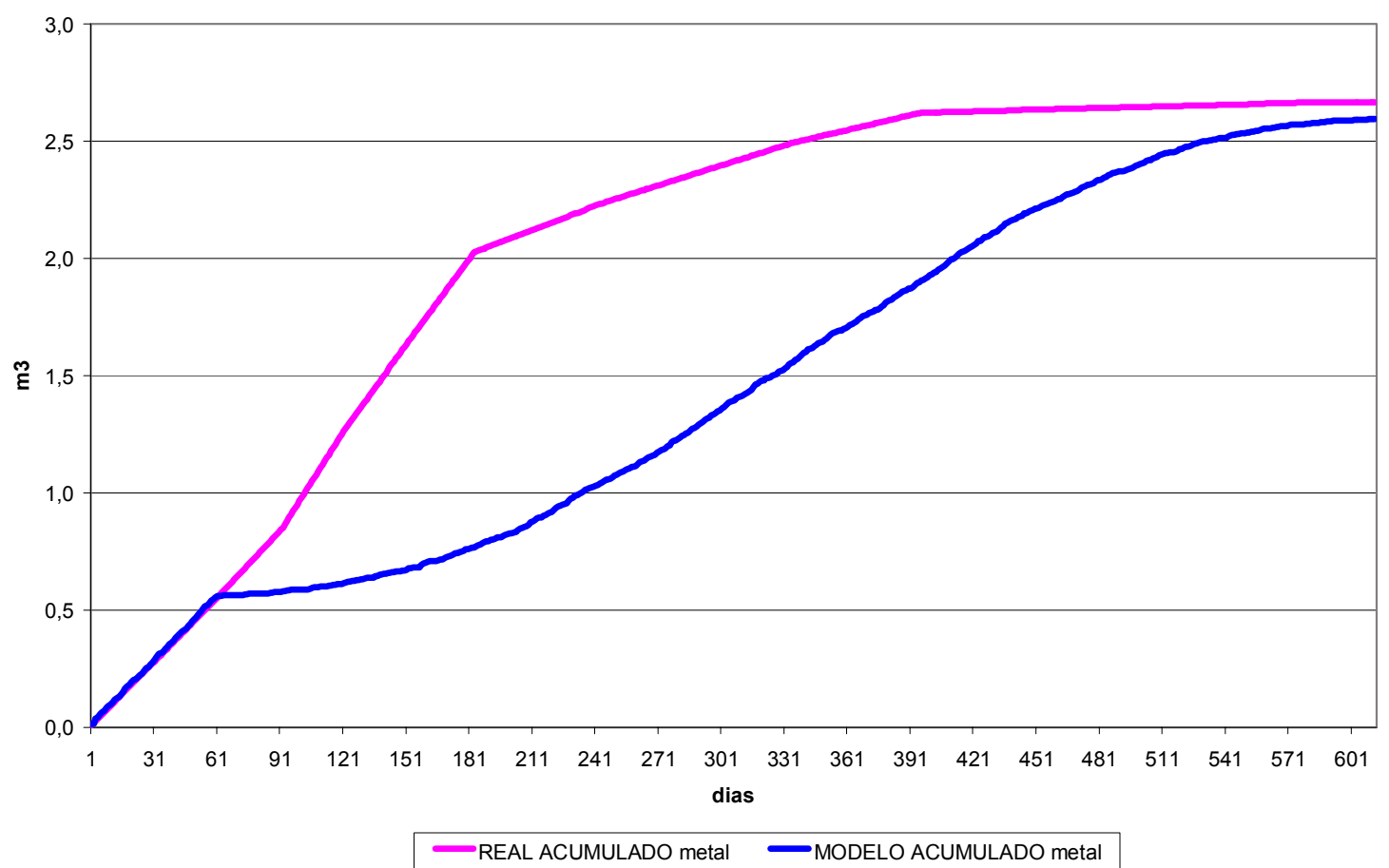

Gráfico 7.16. Geração acumulada de madeira Real X Modelo.

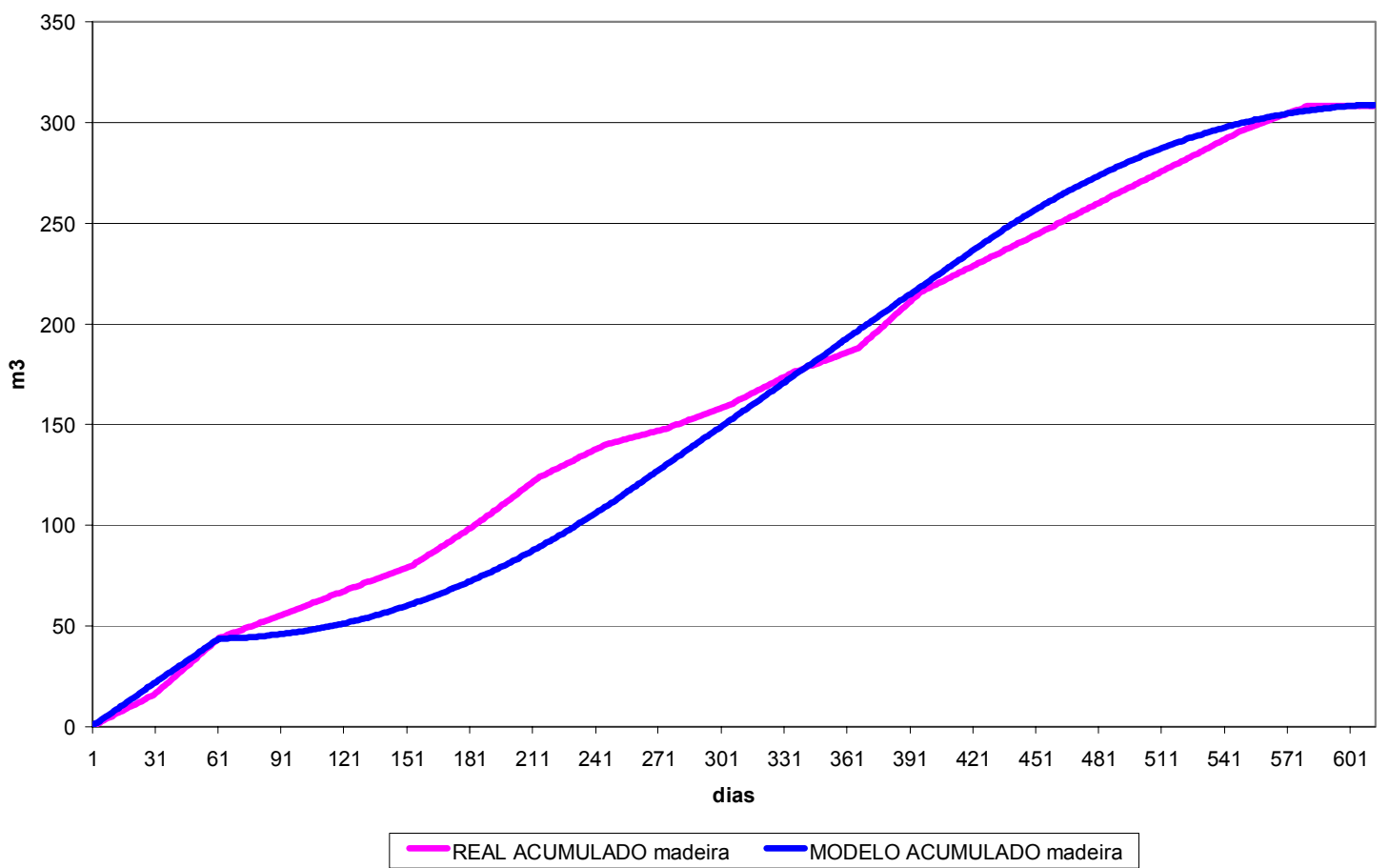


Gráfico 7.17. Geração acumulada de mineral Real X Modelo.

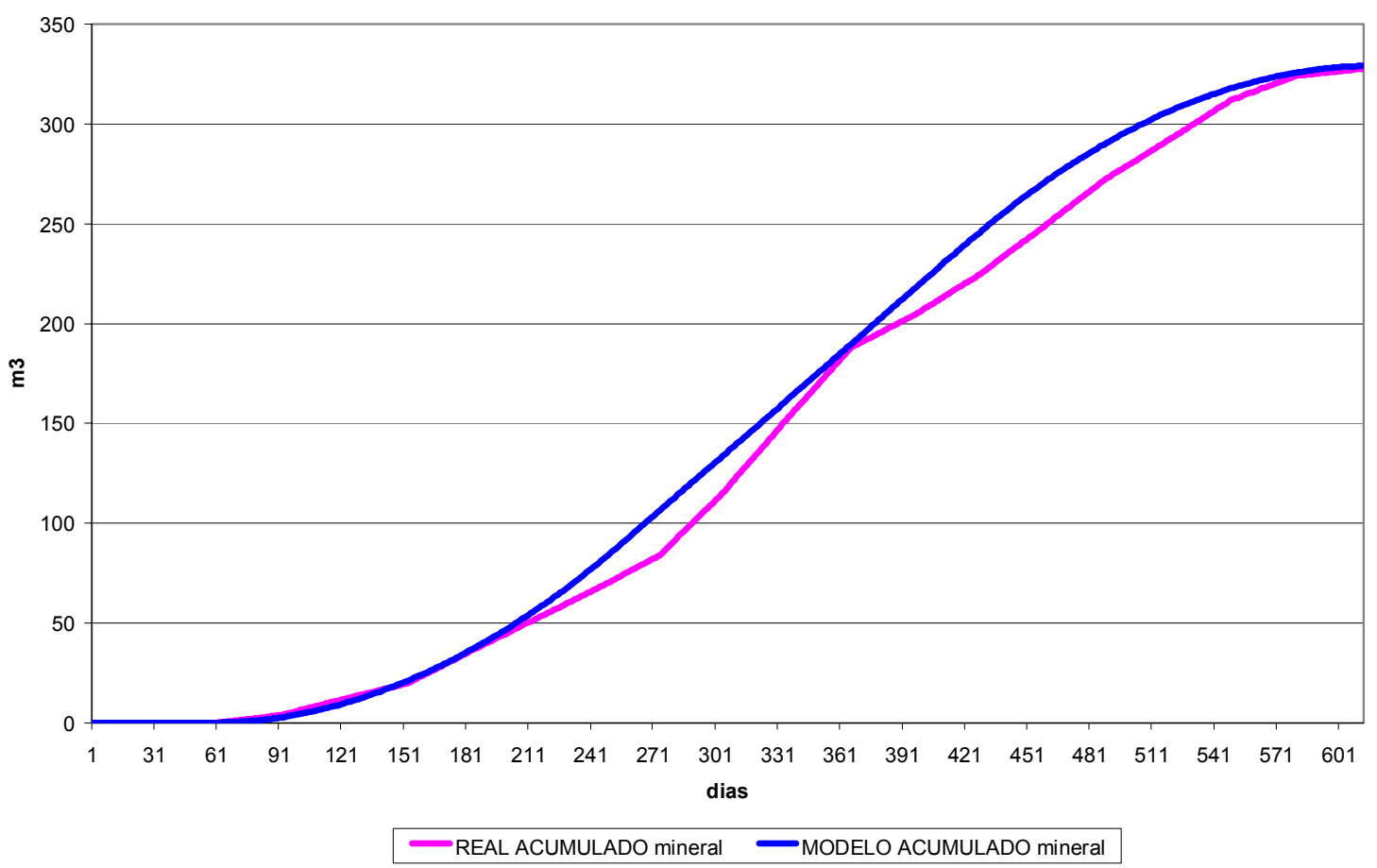

Gráfico 7.18. Geração acumulada de terra Real X Modelo.

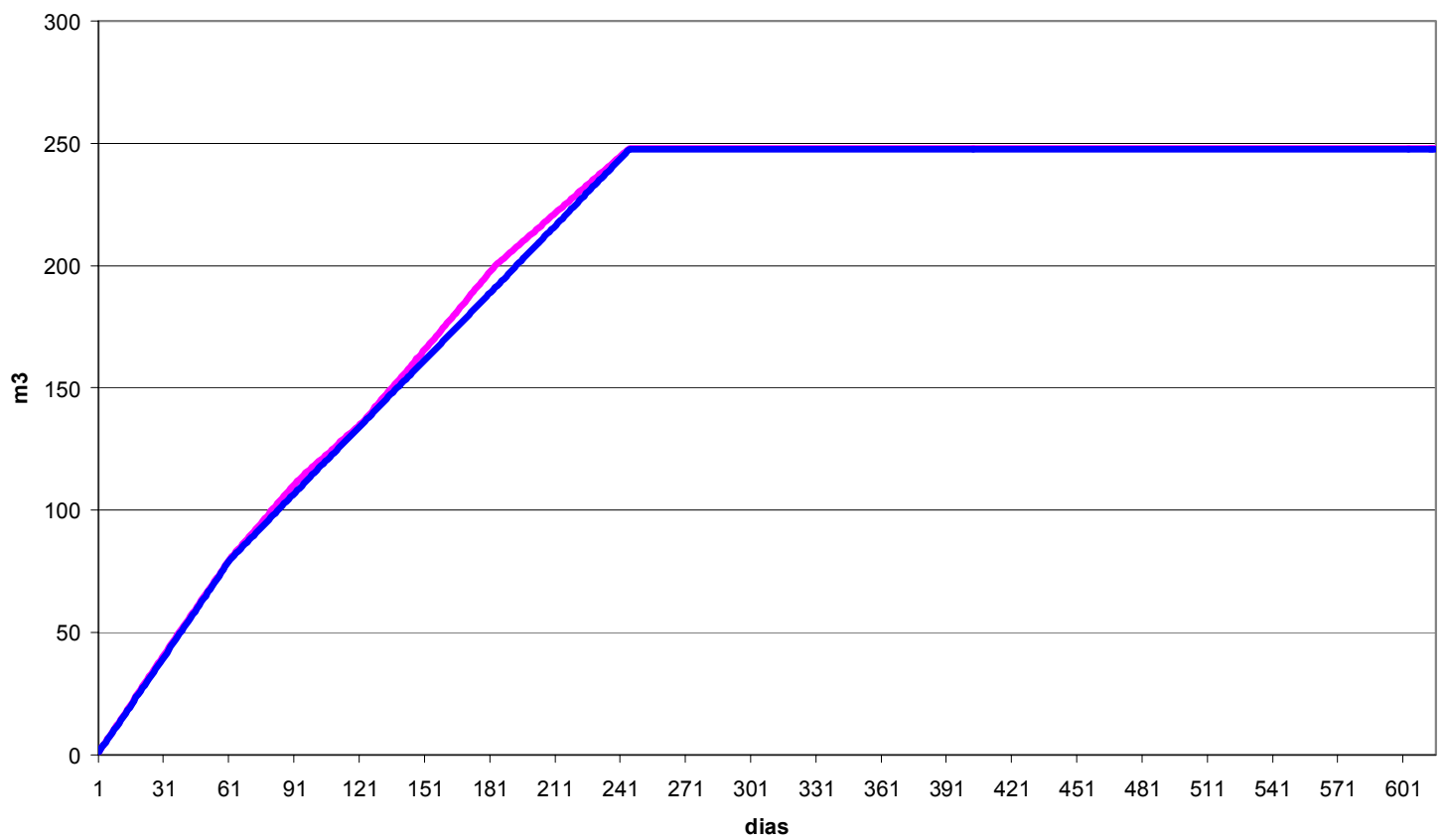


Com a análise desses gráficos, podemos chegar as seguintes conclusões:

Para o papel e o plástico, o modelo representa uma curva média de geração similar, porém defasada da real. Para o metal, a curva do modelo é similar durante a fase de preparação e fundação, porém a curva real assume outra configuração, descolando da curva do modelo. Para a madeira, o mineral e a terra a curva de geração do modelo representa bem a geração real.

Como citado no item 2.6.4, uma das desvantagens da simulação é que ela trabalha com valores médios dos dados de entrada. Dessa forma, os gráficos apresentados acima representam de forma satisfatória a geração de resíduos, com exceção do resíduo de metal. Porém, o volume total de metal gerado é muito baixo (por volta de $2,5 \mathrm{~m}^{3}$ ), não impactando no modelo. Assim, pode-se considerar que a taxa de geração de resíduo no modelo corresponde à taxa de geração real.

Com isso, segue a planilha com os cenários descritos anteriormente, verificando as diferentes combinações de redução e segregação:

Tabela 7.6. Resultado das simulações.

\begin{tabular}{l|c|c|c} 
& SIMULAÇÃO 2 & SIMULAÇÃO 3 & SIMULAÇÃO 4 \\
\hline Redução & não & não & sim \\
Segregação & não & sim & não \\
Resíduo total $\left(\mathrm{m}^{3}\right)$ & $1.085,211$ & $1.085,537$ & 960,618 \\
Custo total $(\mathrm{R} \$)$ & $\mathrm{R} \$ 24.480,00$ & $\mathrm{R} \$ 21.270,00$ & $\mathrm{R} \$ 21.690,00$ \\
Taxa de geração $\left(\mathrm{m}^{3} / \mathrm{m}^{2}\right)$ & 0,199 & 0,199 & 0,176 \\
Taxa de geração $\left(\mathrm{kg} / \mathrm{m}^{2}\right)$ & 238,8 & 177,1 & 211,4
\end{tabular}

\subsection{RESULTADO DAS SIMULAÇÕES DO NOVO MODELO DE RETIRADA DE RESÍDUOS}

Com a confirmação, no item anterior, que a curva de geração dos resíduos madeira, mineral e terra no Modelo se assemelham com a curva de geração real, podemos utilizar os dados levantados no item 7.6, onde determinamos as diferentes fases de geração de cada resíduo, bem como seus valores médios. 
A nova política de transporte será o agendamento da retirada dos resíduos, ao invés da retirada sob demanda. Com isso, tem-se o objetivo de negociar o valor da caçamba, já que existe previsibilidade da retirada.

A princípio, quando esse agendamento ocorre, existe a possibilidade de que caçambas sejam retiradas sem estarem com o volume máximo possível de resíduos. Com isso, no final da obra, seriam retiradas mais caçambas que o necessário e, se não houver redução de custo por caçamba, o valor total seria maior. Dessa forma, a simulação de agendamento será dada da seguinte forma:

Inicialmente será calculado, para cada fase de cada resíduo, qual a média de geração por dia, para obtermos qual a necessidade média de dias para encher uma caçamba. Assim, a primeira simulação será feita de acordo com a freqüência de retirada estabelecida dessa forma. Em seguida, será aumentado em um dia o intervalo de retirada de cada resíduo, em cada fase, com o objetivo de reduzimos a freqüência de retirada.

A situação de contorno dessa redução de freqüência será o estoque de resíduo no piso de um dia para outro. Será admitido que isso ocorra no máximo 65 vezes, que representa aproximadamente $10 \%$ do tempo da obra. Essa limitação é feita pois o resíduo acumulado no piso gera transtorno de movimentação na obra, bem como facilita a contaminação do resíduo e torna o canteiro desorganizado.

O valor do custo da caçamba não será alterado nas simulações. Assim, poderemos comparar o custo de cada simulação e determinar qual o desconto necessário em cada caso para torná-lo viável.

\subsubsection{Retirada da madeira}

Para a retirada da madeira, que é feita em caçambas de $4 \mathrm{~m}^{3}$, foram estudadas duas políticas diferentes: a primeira com a retirada de uma caçamba por vez, com intervalos pré-determinados; e a segunda com a utilização de um caminhão poliguindaste, que retira duas caçambas de $4 \mathrm{~m}^{3}$ por vez, também com o agendamento. Vale ressaltar que 
nesse caso a capacidade da baia de madeira foi aumentada em $4 \mathrm{~m}^{3}$, chegando dessa forma a $12 \mathrm{~m}^{3}$.

Os resultados das simulações foram:

Tabela 7.7. Resultado do agendamento para madeira - política 1.

\begin{tabular}{|c|c|c|c|c|c|c|c|}
\hline & \multirow{2}{*}{ Sob demanda } & \multicolumn{6}{|c|}{ simulações (dias de intervalo entre caçambas) } \\
\hline & & simulação 1 & simulação 2 & simulação 3 & simulação 4 & simulação 5 & simulação 6 \\
\hline$\overline{\text { Fase }}$ & $\bar{n}$ & 5 & 3 & 3 & 4 & 5 & 6 \\
\hline Fase & $\mathrm{n}$ & 11 & 9 & 7 & 7 & 7 & 7 \\
\hline Fase $3(\mathrm{c}$ & na & 5 & 3 & 3 & 4 & 5 & 6 \\
\hline Fase 4 (dia 436 a 615) & na & 11 & 9 & 7 & 7 & 7 & 7 \\
\hline caçambas & 77 & 83 & 122 & 134 & 113 & 101 & 93 \\
\hline dias de uso do piso & 0 & 378 & 84 & 0 & 3 & 3 & 252 \\
\hline $\begin{array}{c}\text { custo total } \\
\text { preço máximo viável }\end{array}$ & $\begin{array}{c}\mathrm{R} \$ 5.850,00 \\
\mathrm{R} \$ 75,00\end{array}$ & $\begin{array}{c}\mathrm{R} \$ 6.225,00 \\
\mathrm{R} \$ 70,48\end{array}$ & $\begin{array}{l}\mathrm{R} \$ 9.150,00 \\
\mathrm{R} \$ 47,95\end{array}$ & $\begin{array}{c}\mathrm{R} \$ 10.050,00 \\
\mathrm{R} \$ 43,66\end{array}$ & $\begin{array}{c}\mathrm{R} \$ 8.475,00 \\
\mathrm{R} \$ 51,77\end{array}$ & $\begin{array}{c}R \$ 7.575,00 \\
R \$ 57,92\end{array}$ & $\begin{array}{c}\mathrm{R} \$ 6.975,00 \\
\mathrm{R} \$ 62,90\end{array}$ \\
\hline
\end{tabular}

Tabela 7.8. Resultado do agendamento para madeira - política 2.

\begin{tabular}{|c|c|c|c|c|c|}
\hline & \multirow{2}{*}{ Sob demanda } & \multicolumn{4}{|c|}{ simulações (dias de intervalo entre caçambas) } \\
\hline & & simulação 1 & simulação 2 & simulação 3 & simulação 4 \\
\hline$\overline{\text { Fase 1 (dia 1 a 61) }}$ & na & $\overline{10}$ & $\overline{10}$ & 10 & 11 \\
\hline Fase 2 (dia 62 a 251 ) & na & 14 & 16 & 15 & 15 \\
\hline Fase 3 (dia 252 a 435 ) & na & 10 & 10 & 10 & 11 \\
\hline Fase 4 (dia 436 a 615$)$ & na & 14 & 16 & 15 & 15 \\
\hline caçambas & 77 & 100 & 94 & 96 & 90 \\
\hline dias de uso do piso & 0 & 4 & 82 & 30 & 217 \\
\hline $\begin{array}{c}\text { custo total } \\
\text { preço máximo viável }\end{array}$ & $\begin{array}{c}\mathrm{R} \$ 5.850,00 \\
\mathrm{R} \$ 75,00\end{array}$ & $\begin{array}{c}\mathrm{R} \$ 7.500,00 \\
\mathrm{R} \$ 58,50\end{array}$ & $\begin{array}{c}\mathrm{R} \$ 7.050,00 \\
\mathrm{R} \$ 62,23\end{array}$ & $\begin{array}{c}\mathrm{R} \$ 7.200,00 \\
\mathrm{R} \$ 60,94\end{array}$ & $\begin{array}{c}\mathrm{R} \$ 6.750,00 \\
\mathrm{R} \$ 65,00\end{array}$ \\
\hline
\end{tabular}

Dessa forma, para a Política 1, o agendamento com o menor custo, que cumpre a situação de contorno, foi a simulação 5. Portanto ele se torna viável desde que o preço máximo por caçamba seja de $\mathrm{R} \$ 57,92$, isto é, uma redução mínima de $22,8 \%$ no preço da retirada de cada caçamba.

Já para a Política 2, a simulação com a melhor condição de agendamento foi a 3, que é viável quando a caçamba retirada com poliguindaste custa no máximo $R \$ 60,94$ cada, que representa um desconto de $18,8 \%$ no preço praticado, de $\mathrm{R} \$ 75,00$. 


\subsubsection{Retirada do mineral}

Da mesma forma que a madeira, o resíduo mineral é retirado em caçambas de $4 \mathrm{~m}^{3}$, assim também foram estudadas duas políticas: retirando $4 \mathrm{~m}^{3}$ por vez; e retirando $8 \mathrm{~m}^{3}$ por vez. De forma semelhante à madeira, para a segunda política, foi adicionada mais uma caçamba na obra, que possuía inicialmente duas. Assim, os resultados foram:

Tabela 7.9. Resultado do agendamento para mineral - política 1.

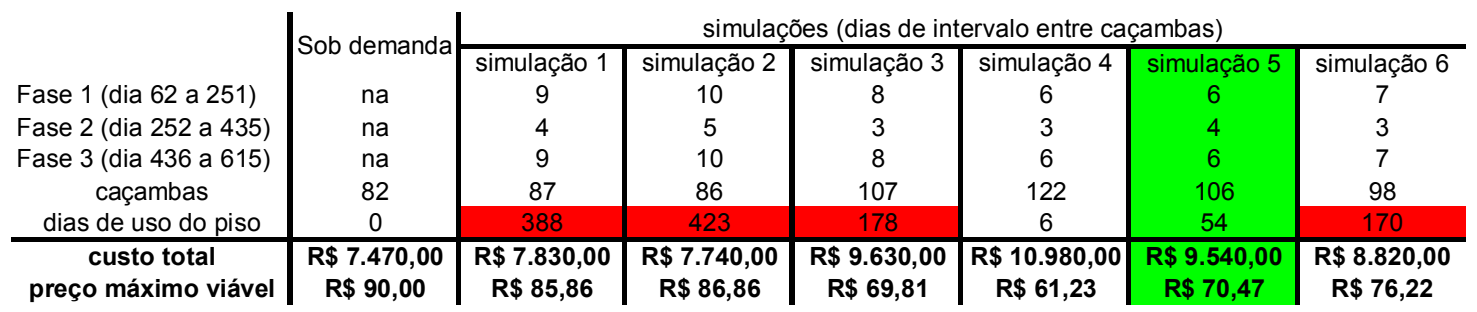

Tabela 7.10. Resultado do agendamento para mineral - política 2.

\begin{tabular}{|c|c|c|c|c|c|}
\hline & \multirow{2}{*}{ Sob demanda } & \multicolumn{4}{|c|}{ simulações (dias de intervalo entre caçambas) } \\
\hline & & simulação 1 & simulação 2 & simulação 3 & simulação 4 \\
\hline Fase 1 (dia 62 a 251$)$ & na & 12 & 11 & 12 & 11 \\
\hline Fase 2 (dia 252 a 435$)$ & na & 8 & 8 & 7 & 9 \\
\hline Fase 3 (dia 436 a 615) & na & 12 & 11 & 12 & 11 \\
\hline caçambas & 82 & 104 & 112 & 112 & 108 \\
\hline dias de uso do piso & 0 & 90 & 25 & 20 & 116 \\
\hline $\begin{array}{c}\text { custo total } \\
\text { preço máximo viável }\end{array}$ & $\begin{array}{c}\mathrm{R} \$ 7.470,00 \\
\mathrm{R} \$ 90,00\end{array}$ & $\begin{array}{c}\mathrm{R} \$ 9.360,00 \\
\mathrm{R} \$ 71,83\end{array}$ & $\begin{array}{c}\mathrm{R} \$ 10.080,00 \\
\mathrm{R} \$ 66,70\end{array}$ & $\begin{array}{c}\mathrm{R} \$ 10.080,00 \\
\mathrm{R} \$ 66,70\end{array}$ & $\begin{array}{c}\mathrm{R} \$ 9.720,00 \\
\mathrm{R} \$ 69,17\end{array}$ \\
\hline
\end{tabular}

Para a Política 1, o agendamento de menor custo é o representado pela simulação 5, que só se torna viável caso haja um desconto mínimo de $21,7 \%$, isto é, que o custo máximo seja de $\mathrm{R} \$ 70,47$.

Para a Política 2, houve um empate de custo entre as simulação 2 e 3, porém foi escolhida aquela que geraria menos dias de resíduo acumulado no piso. Assim, esse agendamento é viável caso cada caçamba, retirada por poliguindaste, custe até $R \$$ 66,70 , isto é, tenha um desconto de $25,9 \%$. 


\subsubsection{Retirada da terra}

No caso da terra, a retirada era feita com caminhões de $20 \mathrm{~m}^{2}$, dessa forma foi proposta uma única política de retirada, que tem suas simulações apresentadas abaixo:

Tabela 7.11. Resultado do agendamento para terra.

\begin{tabular}{|c|c|c|c|c|c|c|c|}
\hline \multirow[b]{2}{*}{ Fase 1 (dia 1 a 61$)$} & \multirow[b]{2}{*}{ Sob demanda } & \multicolumn{6}{|c|}{ simulações (dias de intervalo entre caçambas) } \\
\hline & & $\begin{array}{c}\text { simulação } 1 \\
15\end{array}$ & $\begin{array}{c}\text { simulação } 2 \\
17\end{array}$ & $\begin{array}{c}\text { simulação } 3 \\
18\end{array}$ & $\begin{array}{c}\text { simulação } 4 \\
20\end{array}$ & $\begin{array}{c}\text { simulação } 5 \\
22\end{array}$ & $\begin{array}{c}\text { simulação } 6 \\
17\end{array}$ \\
\hline 245) & na & 21 & 22 & 22 & 22 & 22 & 23 \\
\hline caç & 12 & 13 & 13 & 13 & 13 & 13 & 13 \\
\hline dias de uso do piso & 0 & 0 & 10 & 10 & 10 & 10 & 417 \\
\hline $\begin{array}{c}\text { custo total } \\
\text { preço máximo viável }\end{array}$ & $\begin{array}{r}\$ 5.400,00 \\
R \$ 450,00\end{array}$ & $\begin{array}{r}R \$ 5.850,00 \\
R \$ 415,38\end{array}$ & $\begin{array}{r}\$ 5.850,00 \\
R \$ 415,38\end{array}$ & $\begin{array}{r}\$ 5.850,00 \\
R \$ 415,38\end{array}$ & $\begin{array}{r}\$ 5.850,00 \\
R \$ 415,38\end{array}$ & $\begin{array}{r}R \$ 5.850,00 \\
R \$ 415,38\end{array}$ & $\begin{array}{r}R \$ 5.850,00 \\
R \$ 415,38\end{array}$ \\
\hline
\end{tabular}

Assim, a freqüência de um caminhão a cada 22 dias durante todo o período de geração de terra é a que tem menor custo, e torna-se viável caso o custo por retirada seja no máximo de $\mathrm{R} \$ 415,38$, isto é, uma redução mínima de 7,7\%.

\subsection{CONCLUSÃO DO CAPÍTULO}

Através dos resultados das diferentes simulações, comparados com os resultados da aplicação em um caso, podemos chegar a conclusão que o Plano de Gestão de Resíduos obteve sucesso.

A primeira análise que pode ser feita é em relação ao custo da gestão de resíduo na aplicação em um caso e na Simulação 2, onde não houve nem diminuição da geração de resíduos nem a segregação do resíduo gerado. Assim, podemos avaliar diretamente o impacto do Plano nos custos.

Relembrando esses dados, o custo na aplicação em um caso foi de $R \$ 20.005,00$, sendo que $R \$ 18.735,00$ foram relativos à retirada do resíduo da obra e $R \$ 1.270,00$ relativo aos custos de dispositivos, como bombonas e sacos de ráfia. Na Simulação 2, o resultado foi um custo de $\mathrm{R} \$ 24.480,00$. Dessa forma, houve uma economia de $\mathrm{R} \$$ $4.475,00$, que representa uma diminuição de $18,3 \%$ do custo. 
Porém, quanto desse custo foi economizado pela redução da quantidade de resíduo gerado e quanto desse custo é resultado da segregação? Com a análise das Simulações 3 e 4, podemos chegar a seguinte análise:

A Simulação 3, que representa a hipótese do Edifício Piloto fazendo somente segregação, teve um custo de retirada de resíduo de $\mathrm{R} \$ 21.270,00$. Somando os custos de dispositivos, esse valor chega a $R \$ 22.540,00$, que representa uma economia de $R \$$ $1.940,00$, ou $43,3 \%$ da economia total da aplicação em um caso em relação à não execução do Plano de Gestão (Simulação 2).

Já a simulação 4, que representa somente a redução de $11 \%$ na quantidade de resíduo gerado, obteve um custo de destinação de resíduo de $\mathrm{R} \$ 21.690,00$. Com isso, ocorre uma economia de $\mathrm{R} \$ 2.790,00$, ou uma economia que representa $62,3 \%$ da economia total que ocorre com a aplicação do Plano de Gestão.

Assim, podemos concluir que, tanto a redução da geração de resíduos como a segregação do resíduo gerado trouxeram benefícios relevantes. A diferença entre ambos é que a economia gerada pela diminuição da geração foi $\mathrm{R} \$ 850,00$ maior que a economia gerada somente pela segregação dos resíduos. Porém vale lembrar que, quando existe a segregação, existe um custo de $R \$ 1.270,00$ de dispositivos.

Para as políticas de retirada de resíduos da obra fica claro que, para realizar a agendamento da retirada de caçambas com uma freqüência constante em cada fase, é necessária a redução dos custos cobrados por caçamba. Assim, para a madeira a melhor situação de agendamento é a utilização de poliguindaste, desde que exista um desconto mínimo de $18,8 \%$ no custo por caçamba. No caso do resíduo mineral é o agendamento de retirada de uma caçamba por vez, desde que o desconto no preço por caçamba ultrapasse $21,7 \%$. Para a retirada de terra, o agendamento é valido para um desconto acima de $7,7 \%$. 


\section{CAPÍTULO 8. CONCLUSÃO, COMENTÁRIOS E RECOMENDAÇÕES}

Este trabalho abordou a Gestão de Resíduos de Construção Civil, de forma que essa gestão fosse feita seguindo os parâmetros definidos na Resolução CONAMA 307. Para essa abordagem, foi proposto um Plano de Gestão de Resíduos.

Esse Plano de Gestão de Resíduos foi elaborado através do estudo do subsistema interno à obra, isto é, analisando a geração do resíduo, sua segregação, o transporte interno desse resíduo e sua retirada para deposição final ou reciclagem de forma apropriada.

Para verificar sua eficácia, o Plano de Gestão foi aplicado à obra de um edifício sendo que outro edifício da mesma Construtora, onde não houve nenhuma forma de gestão de resíduos, foi utilizado como controle. A aplicação do Plano ocorreu nos níveis estratégico, tático e operacional da Construtora. Os resíduos das Classes C e D da Resolução CONAMA 307 não fizeram parte do Plano, já que até sua implantação ainda não haviam sido determinados locais para deposição final ou reciclagem desses resíduos.

Os resultados dessa aplicação demonstraram que o Plano atendeu à Resolução CONAMA 307 e que isso foi feito de forma social, ambiental e economicamente viável. Um modelo de simulação foi feito para avaliar o impacto do Plano na diminuição da geração de resíduo e sua segregação.

Através desse modelo, elaborado no programa Arena 7.0, foi possível estudar diferentes simulações abrangendo a ocorrência ou não da diminuição da geração do resíduo, combinado com sua segregação. Também foram simuladas diferentes políticas de retirada de resíduo, utilizando caminhões com capacidades diversas e com retirada sob demanda ou agendada. Essas simulações permitiram quantificar a viabilidade econômica do Plano, bem como propor novas políticas de retiradas de resíduos.

Através dos resultados das diferentes simulações, comparados com os resultados da aplicação em um caso, foi possível constatar que o problema da Gestão de Resíduo pode ser analisado e modelado com base no enfoque sistêmico e no uso da simulação, 
atendendo de forma viável a legislação vigente para esse assunto, em especial a Resolução CONAMA 307.

Sobre o tratamento dos resíduos, percebe-se a necessidade de trabalhar e desenvolver melhor o tratamento dado aos resíduos Classe C e D. No caso do gesso, o resíduo de placas de gesso foi insignificante e encaminhado para aterro sanitário através da coleta pública e o gesso liso foi incorporado ao solo de reaterro das fundações. Essa não é a melhor solução, porém no período da obra ainda não havia uma ATT autorizada a receber gesso. Situação semelhante ocorreu com os resíduos da impermeabilização. Os recortes de manta foram encaminhados também à limpeza pública e os aparelhos de aplicação, como os pincéis, eram de responsabilidade dos aplicadores, então não eram adicionados ao resíduo da obra. Até hoje não existe ainda uma ATT que possa receber esse material

Um dos pontos mais vulneráveis, que se destacou no processo, foi o de transporte e destinação dos resíduos. Apesar de não terem ocorrido problemas com esses serviços, sabe-se que ambos os mercados são extremamente voláteis (BARBOSA, 2003). Isso porque empresas entram e saem desses mercados, principalmente no de transporte, e muitas vezes é difícil para a Construtora acompanhar essas mudanças.

A Política de agendamento da retirada de resíduos, com o estabelecimento de uma freqüência definida de retirada de cada resíduo, dentro de cada fase de sua geração, apresentou soluções diversas. Para a madeira, a melhor solução seria o uso de poliguindaste, retirando duas caçambas por vez. Para o resíduo mineral, a solução de retirar uma caçamba por vez se mostrou a melhor, enquanto que para a terra a solução de poliguindaste não foi considerada, pois já eram retirados $20 \mathrm{~m}^{3}$ por viagem. Nos três casos, esse agendamento gerou mais custo que a retirada sob demanda, porém o valor do desconto para viabilizar esses agendamento é factível, principalmente no caso da terra.

Como recomendação a outras experiências do gênero, vale reforçar a base fundamental permeada por todo esse trabalho: a logística. O tratamento de resíduos de construção civil pode não parecer um tema muito ligado a logística, porém ele não pode ser tratado de uma forma isolada, como um passivo que é inerente ao processo de 
construção e precisa ser descartado. Dentro do sistema logístico, existe o papel fundamental de estruturar toda a cadeia de processos que leva, por fim, à geração desse resíduo, bem como, após essa geração, tratar de seu transporte, deposição e respectiva documentação de forma a agregar valor ao processo.

Como proposta de continuação desse trabalho, cabe disseminar o processo de aplicação da Gestão de Resíduos por todo o país, principalmente fora das grandes capitais. Isso será um enorme desafio a empresas e governos, já que os recursos disponibilizados no município de São Paulo muitas vezes inexistem em outras áreas.

Da mesma forma, um estudo de como esse assunto é tratado em outros países também tem muito a acrescentar. Como foi dito anteriormente, as experiências internacionais possuem um nível de sofisticação muito maior que a necessária no Brasil. Porém, isso não invalida, de forma alguma, seu estudo aprofundado e a conseqüente formulação de propostas de adaptação dessas experiências à nossa realidade. 


\section{ANEXOS}




\section{ANEXO I}

Análise da legislação

\section{Município de São Paulo - Lei n 10.315, de 30 de abril de 1987. Prefeito: Jânio Quadros}

"Dispõe sobre a limpeza pública do Município de São Paulo"

Art. $3^{\circ}$ inc. VI - Cabe a Prefeitura a remoção de entulho, terra e sobras de materiais de construção que não pesem mais de 50 quilos, devidamente acondicionados. Art. $6^{\circ}$ inc. IV $\S 1^{\circ}$ - Caso não proceda a remoção prevista neste artigo, a Prefeitura indicará o local de destino dos resíduos sólidos...

Art. 23 - É proibido expor ou depositar no passeio, canteiros, jardins, área e logradouros públicos,..., materiais de construção, entulho, terra ou resíduos de qualquer natureza, sob pena de apreensão dos mesmos, bem como dos veículos que os estejam transportando, e pagamento das despesas de remoção.

Comentários:

- Trata o assunto lixo e RCD de forma geral, necessitando de regulamentação;

- Indica o critério de pequeno gerador (50 kg);

- A Prefeitura é responsável por indicar o local de destino dos resíduos gerados na cidade, sem distinção do tipo. O que fazer com classe A, B, C e D?

- A responsabilidade pelo depósito ilegal é do transportador do resíduo.

\section{Município de São Paulo - Decreto n 42.217, de 24 de julho de 2002. Prefeito: Marta Suplicy}

"Regulamenta a Lei n 10.315, de 30 de abril de 1987, no que se refere ao uso de áreas destinadas ao transbordo e triagem de resíduos de construção civil, e resíduos volumosos, na forma que especifica, e dá outras providências".

A motivação dessa lei é baseada no artigo $7^{\circ}$ da Lei Orgânica do Município de São Paulo, que diz que é "dever do Poder Público Municipal assegurar a todos os munícipes 
meio ambiente humanizado, sadio e ecologicamente equilibrado". Com isso, a Lei considera que essas áreas permitirão "resguardar a qualidade de vida e as condições ambientais de áreas contíguas aos empreendimentos", que a reciclagem de RCD economiza matéria-prima virgem não-renovável, que o descarte irregular irá diminuir com o aumento do número de ATTs, que a criação de um grande número dessas áreas irá reduzir a distância de transporte e que existirá economia de recursos municipais com a coleta de resíduos ilegais e conseqüente otimização dos equipamentos de coleta e transporte a cargo do Município.

Pela definição do Decreto, temos:

- Resíduos de CC: Materiais residuais oriundos de construções, reformas, reparos, restaurações e demolições de obras de construção civil, bem como os resultantes da preparação e escavação de terrenos, tais como tijolos, blocos cerâmicos, concreto em geral, solo, rocha, madeira, forros, argamassa, gesso, telhas, pavimento asfáltico, vidros, plásticos, tubulações, fiação elétrica, metais, todos comumente denominados de entulho de obras;

- Resíduos volumosos - os resíduos não provenientes de processos industriais, constituídos basicamente por material volumoso não removido pela coleta pública municipal rotineira, como móveis e equipamentos domésticos inutilizados, grandes embalagens e peças de madeira, podas e assemelhados;

Os pontos de entrega dos materiais são divididos em dois tipos, um público e um privado:

- Pontos de Entrega (Pequenos Volumes) - os equipamentos públicos destinados ao recebimento de resíduos da construção civil e resíduos volumosos limitados a 1 (um) metro cúbico, gerados e entregues pelos munícipes ou por pequenos coletores diretamente contratados pelos geradores, e que deverão ser usados para a triagem de resíduos recebidos, posterior coleta diferenciada e remoção, para adequada disposição; além disso, os Pontos de Entrega, sem comprometimento de suas funções, poderão ser utilizados de forma compartilhada por grupos locais que desenvolvam ações de coleta seletiva de resíduos sólidos recicláveis, de origem domiciliar. 
- Áreas de Transbordo e Triagem de Resíduos da Construção Civil - ATT - os estabelecimentos privados destinados ao recebimento de resíduos da construção civil e resíduos volumosos gerados e coletados por agentes privados, e que deverão ser usadas para a triagem dos resíduos recebidos, eventual transformação e posterior remoção para adequada disposição;

O decreto estipula todas as condições necessárias para o funcionamento de ambos.

Para deposição final, são definidos os Aterros de Resíduos da Construção Civil, como áreas para disposição de resíduos minerais no solo, utilizando princípios de engenharia para confiná-los ao menor volume possível, com o máximo de compactação permissível, sem causar danos à saúde pública e ao meio ambiente, visando a reservação de minerais segregados, de forma a possibilitar seu uso futuro ou da área.

Para a reutilização das áreas, tanto dos pontos intermediários como do depósito final, será necessário projeto de recuperação ambiental, devidamente analisados e aprovados pelo Departamento de Controle da Qualidade Ambiental - DECONT, da Secretaria Municipal do Meio Ambiente.

Nos Pontos de Entrega, ATTs e Aterros não será permitido o recebimento de cargas de resíduos de construção civil constituídas predominantemente por resíduos da construção civil perigosos e não-inertes (tintas, solventes, óleos, resíduos provenientes de instalações industriais e outros), enquadrados como Classe I da NBR 10.004; os demais tipos de resíduos da construção civil e os resíduos volumosos deverão ser encaminhados à reutilização, reciclagem, armazenagem ou a aterros adequados, obedecidas as normas técnicas específicas. No caso de solos de escavação, pode-se encaminhá-los diretamente para cobertura de Aterros Sanitários.

O decreto demonstra, em anexo, como deve ser o Controle de Transporte de Resíduos (CTR).

Comentários:

- Na motivação do decreto, não é considerada a poluição e os danos ambientais e a saúde causados pela deposição ilegal do RCD; 
- Os Pontos de Entrega (Pequenos Volumes) só pode ser estabelecido pelo município, enquanto as ATTs somente podem ser privadas. O ideal seria que ambos pudessem ser públicos ou privados, dependendo dos interesses de investimento de ambas as partes;

- Na definição de Aterros de Resíduos da Construção Civil, só é permitida a deposição de resíduos classe A;

- Os pontos de entrega devem preferencialmente ocupar áreas já degradadas pelo depósito de entulho. Isso é uma boa iniciativa, já que recupera a área, e esse local se demonstra um ponto preferencial de descarte;

- Os Pontos de Entrega podem receber recicláveis de origem domiciliar. Por que as ATTs não tem essa possibilidade?

- Nos Pontos de Entrega e ATTs só pode ser recebido RCD Classe A e B. E as outras classes?

- No CTR não existe um campo com o endereço da Área de Disposição Final de Resíduos. Como fiscalizar no caminho?

\section{Município de São Paulo - Lei n 13.298, de 16 de janeiro de 2002. Prefeito: Marta Suplicy}

(Projeto de Lei n 191/01, do Vereador Ricardo Montoro - PSDB)

"Dispõe sobre as responsabilidades e condições de remoção de entulho, terra e materiais de construção".

Art. $1^{\circ}$ - Os proprietários, possuidores, incorporadores e construtores de imóveis, geradores de resíduos de construção civil responderão com as empresas ou prestadoras de serviços de remoção, transporte e destinação final desses materiais inertes, quanto ao cumprimento dos dispositivos aplicáveis da Lei 10.315, de 30 de abril de 1987 a eles aplicáveis.

$\S 1^{\circ}$ - As partes responderão pelas respectivas atividades que, por contrato, sejam combinadas a cada uma, dentro dos correspondentes limites de responsabilidade quanto à qualidade do material a ser removido, ao cumprimento das exigências de 
transporte e de segurança de trânsito e à destinação final dos resíduos.

$\S 2^{\circ}$ - Na ausência de contrato, as partes responderão solidariamente pela destinação final dos resíduos.

Art. $2^{\circ}$ - A empresa ou prestador de serviço contratado para remoção não abrangida pela coleta regular, devem comunicar previamente à Municipalidade, quanto à remoção e a destinação dos resíduos de que trata o artigo $1^{\circ}$ desta lei.

Parágrafo único - A empresa ou prestador de serviço contratado deverá fornecer ao gerador dos resíduos comprovante declarando a sua correta destinação.

Comentários:

- Ao contrário da Lei 10.315, estende a responsabilidade do RCD depositado irregularmente ao gerador, de forma definida em contrato, ou na falta dele, de forma solidária;

- O transportador deve comunicar antecipadamente a retirada e o local de deposição do RCD;

- O transportador deve comprovar depósito em local regular. Com isso, pode-se condicionar o pagamento do serviço a apresentação do comprovante.

\section{Município de São Paulo - Decreto n 42.833, de 06 de fevereiro de 2003. Prefeito: Marta Suplicy}

"Regulamenta o procedimento de fiscalização ambiental no Município de São Paulo e dá outras providências".

- A fiscalização será feita pela SVMA - Secretaria Municipal do Verde e do Meio Ambiente;

- Determina as sanções e sua cumulatividade;

- Caracteriza o Termo de Ajustamento de Conduta;

- Caracteriza os procedimentos administrativos. 


\section{Município de São Paulo - Decreto n 46.594, de 03 de novembro de 2005. Prefeito: José Serra}

"Capítulo I

Dos Grandes Geradores

Art. $1^{\circ}$. Os proprietários, possuidores ou titulares de estabelecimentos públicos, institucionais, de prestação de serviços, comerciais e industriais, dentre outros, geradores de resíduos sólidos inertes, tais como entulhos, terra e materiais de construção, com massa superior a 50 (cinqüenta) quilogramas diários, de produção contínua e não sujeita a prazo, ficam obrigados a proceder ao seu cadastramento na Autoridade Municipal de Limpeza Urbana - AMLURB, nos termos do artigo 140 da Lei ${ }^{\circ}$ 13.478 , de 30 de dezembro de 2002, e deste decreto, conforme modelo constante do Anexo I integrante deste decreto."

Comentários:

- Reafirma o valor de 50 kg diários de geração como caracterização de grande gerador.

\section{Estado de São Paulo - Resolução SMA n 41, de 17 de outubro de 2002. Governador: Geraldo Alckmin}

"Dispõe sobre procedimentos para o licenciamento ambiental de aterros de resíduos inertes e da construção civil no Estado de São Paulo".

Considera que a construção civil gera grande quantidade de resíduos que, se dispostos em locais inadequados, contribuem para a degradação da qualidade ambiental; e que representam um significativo percentual dos resíduos sólidos produzidos nas áreas urbanas; 
Considera que as cavas de mineração resultantes da atividade minerária constituem degradação ambiental, além de sério risco à saúde da população, por facilitar a proliferação de vetores de doenças e provocar freqüentes casos de morte por Ef como lagoas, lagos ou reservatórios artificiais, como definido no Código Florestal;

A disposição final dos resíduos classificados como classe A, pela Resolução CONAMA 307, de 05/07/2002 e de resíduos inertes classificados como classe III, pela NBR 10.004 - Classificação de Resíduos da ABNT, deverá ser feita em aterros que atendam às normas e exigências estabelecidas pelos órgãos ambientais competentes, a saber: DAIA - Departamento de Avaliação de Impacto Ambiental, DUSM - Departamento de Uso do Solo Metropolitano, DEPRN - Departamento Estadual de Proteção de Recursos Naturais e CETESB - Companhia de Tecnologia de Saneamento Ambiental.

Os aterros cuja capacidade total não exceda 100.000 m3 e que recebam uma quantidade de resíduos igual ou inferior a 150 m3 por dia, serão dispensados de licenciamento ambiental prévio, no âmbito da SMA/DAIA, procedendo-se o licenciamento ambiental no âmbito da CETESB.

Os aterros cuja capacidade total seja inferior ou igual a $100.000 \mathrm{~m} 3$ e que recebam uma quantidade de resíduos superior a $150 \mathrm{~m} 3$ por dia e inferior ou igual a $300 \mathrm{~m} 3$ por dia, dependerão de consulta, a ser encaminhada pela agência ambiental da CETESB, ao Departamento de Avaliação de Impacto Ambiental - DAIA da SMA para manifestação acerca da necessidade de licenciamento ambiental prévio por aquele departamento.

Os aterros cuja capacidade total seja superior a $100.000 \mathrm{~m} 3$ ou que recebam uma quantidade de resíduos superior a $300 \mathrm{~m} 3$ por dia dependerão do licenciamento ambiental prévio da SMA/DAIA, nos termos da Resolução SMA n 42, de 29 de dezembro de 1994, mediante a apresentação de RAP na agência ambiental da CETESB.

Os aterros para a disposição dos resíduos que, simultaneamente, ocupem área igual ou inferior a $1.000 \mathrm{~m} 2$, volume total igual ou inferior a $1.000 \mathrm{~m} 3$ e tenha como finalidade imediata a regularização de terrenos para fins de edificação ficam dispensados do 
licenciamento ambiental, porém, sujeitos à manifestação do DEPRN, e do DUSM quando localizado em APM.

Os aterros que serão implantados em cavas exauridas de mineração terão o licenciamento ambiental vinculado à prévia aprovação de um PRAD - Plano de Recuperação de Área Degradada ou do RCA/PCA - Relatório de Controle Ambiental e Plano de Controle Ambiental, ou documento equivalente.

Os aterros mencionados no artigo $2^{\circ}$ em operação na data de publicação desta Resolução deverão solicitar junto à CETESB a respectiva licença de funcionamento, em um prazo máximo de 180 (cento e oitenta dias), contados a partir da data de publicação desta Resolução.

Comentários:

- Reconhece que o RCD representa grande parte do resíduo sólido gerado;

- Divide os aterros por capacidade, facilitando a burocracia para aterros menores;

- Pode-se utilizar resíduos Classe A para nivelamento de terrenos de até $1000 \mathrm{~m} 2$ sem necessidade de autorização, desde que não esteja em área de proteção de mananciais;

- Considera o uso de cavas de mineração como local para disposição.

\section{Governo Federal: CONAMA Resolução n 307, de 5 de julho de 2002. Presidente do Conselho: José Carlos Carvalho}

Considera a necessidade de implementação de diretrizes para a efetiva redução dos impactos ambientais gerados pelos resíduos oriundos da construção civil, que a disposição de resíduos da construção civil em locais inadequados contribui para a degradação da qualidade ambiental e que os resíduos da construção civil representam um significativo percentual dos resíduos sólidos produzidos nas áreas urbanas.

Considera que os geradores de resíduos da construção civil devem ser responsáveis pelos resíduos. 
Considera a viabilidade técnica e econômica de produção e uso de materiais provenientes da reciclagem de resíduos da construção civil.

Considera que a gestão integrada de resíduos da construção civil deverá proporcionar benefícios de ordem social, econômica e ambiental.

É dada a caracterização de RCD, Geradores, Transportadores, Agregado Reciclado, Gerenciamento de Resíduos, discrimina as diferenças entre reutilização, reciclagem e beneficiamento.

Os resíduos da construção civil são classificados como:

I - Classe A - são os resíduos reutilizáveis ou recicláveis como agregados, tais como:

a) de construção, demolição, reformas e reparos de pavimentação e de outras obras de infra-estrutura, inclusive solos provenientes de terraplanagem;

b) de construção, demolição, reformas e reparos de edificações: componentes cerâmicos (tijolos, blocos, telhas, placas de revestimento etc.), argamassa e concreto;

c) de processo de fabricação e/ou demolição de peças pré-moldadas em concreto (blocos, tubos, meios-fios etc.) produzidas nos canteiros de obras; II - Classe B - são os resíduos recicláveis para outras destinações, tais como: plásticos, papel/papelão, metais, vidros, madeiras e outros;

III - Classe C - são os resíduos para os quais não foram desenvolvidas tecnologias ou aplicações economicamente viáveis que permitam a sua reciclagem/recuperação, tais como os produtos oriundos do gesso;

IV - Classe D - são os resíduos perigosos oriundos do processo de construção, tais como: tintas, solventes, óleos e outros, ou aqueles contaminados oriundos de demolições, reformas e reparos de clínicas radiológicas, instalações industriais e outros.

Os resíduos da construção civil deverão ser destinados das seguintes formas: I - Classe A: deverão ser reutilizados ou reciclados na forma de agregados, ou encaminhados a áreas de aterro de resíduos da construção civil, sendo dispostos de modo a permitir a sua utilização ou reciclagem futura; II - Classe B: deverão ser reutilizados, reciclados ou encaminhados a áreas de armazenamento temporário, sendo dispostos de modo a permitir a sua utilização ou reciclagem futura; 
III - Classe C: deverão ser armazenados, transportados e destinados em conformidade com as normas técnicas especificas.

IV - Classe D: deverão ser armazenados, transportados, reutilizados e destinados em conformidade com as normas técnicas especificas.

Os geradores deverão ter como objetivo prioritário a não geração de resíduos e, secundariamente, a redução, a reutilização, a reciclagem e a destinação final.

É instrumento para a implementação da gestão dos resíduos da construção civil o Plano Integrado de Gerenciamento de Resíduos da Construção Civil, a ser elaborado pelos Municípios e pelo Distrito Federal, o qual deverá incorporar:

I - Programa Municipal de Gerenciamento de Resíduos da Construção Civil; e II - Projetos de Gerenciamento de Resíduos da Construção Civil.

Deverão constar do Plano Integrado de Gerenciamento de Resíduos da Construção Civil: I - as diretrizes técnicas e procedimentos para o Programa Municipal de Gerenciamento de Resíduos da Construção Civil e para os Projetos de Gerenciamento de Resíduos da Construção Civil a serem elaborados pelos grandes geradores, possibilitando o exercício das responsabilidades de todos os geradores;

II - o cadastramento de áreas, públicas ou privadas, aptas para recebimento, triagem e armazenamento temporário de pequenos volumes, em conformidade com o porte da área urbana municipal, possibilitando a destinação posterior dos resíduos oriundos de pequenos geradores às áreas de beneficiamento;

III - o estabelecimento de processos de licenciamento para as áreas de beneficiamento e de disposição final de resíduos;

IV - a proibição da disposição dos resíduos de construção em áreas não licenciadas; V - o incentivo a reinserção dos resíduos reutilizáveis ou reciclados no ciclo produtivo; VI - a definição de critérios para o cadastramento de transportadores;

VII - as ações de orientação, de fiscalização e de controle dos agentes envolvidos; VIII - as ações educativas visando reduzir a geração de resíduos e possibilitar a sua segregação.

O Programa Municipal de Gerenciamento de Resíduos da Construção Civil será elaborado, implementado e coordenado pelos municípios e pelo Distrito Federal, e deverá estabelecer diretrizes técnicas e procedimentos para o exercício das 
responsabilidades dos pequenos geradores, em conformidade com os critérios técnicos do sistema de limpeza urbana local.

Os Projetos de Gerenciamento de Resíduos da Construção Civil serão elaborados e implementados pelos geradores de grande porte e terão como objetivo estabelecer os procedimentos necessários para o manejo e destinação ambientalmente adequados dos resíduos. O Projeto de Gerenciamento de Resíduos da Construção Civil, de empreendimentos e atividades não enquadrados na legislação como objeto de licenciamento ambiental, deverá ser apresentado juntamente com o projeto do empreendimento para análise pelo órgão competente do poder público municipal, em conformidade com o Programa Municipal de Gerenciamento de Resíduos da Construção Civil.

Os Projetos de Gerenciamento de Resíduos da Construção Civil deverão contemplar as seguintes etapas:

I - caracterização: nesta etapa o gerador deverá identificar e quantificar os resíduos; II - triagem: deverá ser realizada, preferencialmente, pelo gerador na origem, ou ser realizada nas áreas de destinação licenciadas para essa finalidade, respeitadas as classes de resíduos estabelecidas no art. $3^{\circ}$ desta Resolução;

III - acondicionamento: o gerador deve garantir o confinamento dos resíduos após a geração até a etapa de transporte, assegurando em todos os casos em que seja possível, as condições de reutilização e de reciclagem;

IV - transporte: deverá ser realizado em conformidade com as etapas anteriores e de acordo com as normas técnicas vigentes para o transporte de resíduos; V - destinação: deverá ser prevista de acordo com o estabelecido nesta Resolução.

Prazos:

Programa Municipal de Gerenciamento de Resíduos da Construção Civil: elaboração até janeiro de 2004 e implementação em junho de 2004.

Projeto de Gerenciamento de Resíduos da Construção Civil: janeiro de 2005.

Comentários:

- Considera o gerador responsável pelo RCD;

- Considera a viabilidade técnica e econômica do RCD; 
- Classifica os resíduos em Classes A, B, C e D, porém só indica o tratamento para as Classes A e B;

- Caracteriza as responsabilidades dos Municípios e geradores no planejamento para o tratamento do RCD;

- Dá tratamento diferenciado a gerador de pequeno e grande porte, mas não quantifica o ponto de mudança entre eles. Será $50 \mathrm{~kg}$. por dia (Lei n 10.315 -

- EMA(B) Réce os prazos.

Não diferencia os municípios por tamanho e/ou capacidade de aplicação da resolução. Grande quantidade de municípios não tem nem aterro sanitário, quanto mais a capacidade de estabelecer pelo menos quatro destinos diferentes, para cada Classe.

\section{Governo Federal: CONAMA Resolução n 348, de 16 de agosto de 2004. Presidente do Conselho: Marina Silva}

Considerando o previsto na Convenção de Basiléia sobre Controle de Movimentos Transfronteiriços de Resíduos Perigosos e seu Depósito, promulgada pelo Decreto Federal no 875 , de 19 de julho de 1993, que prevê em seu art. 10, item 1, alínea "a" e anexo I, que considera o resíduo do amianto como perigoso e pertencente à classe $\mathrm{Y} 36$; Considerando a Resolução CONAMA no 235, de 7 de janeiro de 1998, que trata de classificação de resíduos para gerenciamento de importações, que classifica o amianto em pó (asbesto) e outros desperdícios de amianto como resíduos perigosos classe I de importação proibida, segundo seu anexo X;

Considerando o Critério de Saúde Ambiental no 203, de 1998, da Organização Mundial da Saúde-OMS sobre amianto crisotila que afirma entre outros que "a exposição ao amianto crisotila aumenta os riscos de asbestose, câncer de pulmão e mesotelioma de maneira dependente em função da dose e que nenhum limite de tolerância foi identificado para os riscos de câncer", resolve:

Art. $10 \mathrm{O}$ art. 3o, item IV, da Resolução CONAMA no 307, de 5 de julho de 2002, passa a vigorar com a seguinte redação:

"Art. 30

IV - Classe "D": são resíduos perigosos oriundos do processo de construção, tais como tintas, solventes, óleos e outros ou aqueles contaminados ou prejudiciais à saúde oriundos de demolições, reformas e reparos de clínicas radiológicas, instalações industriais e outros, 
bem como telhas e demais objetos e materiais que contenham amianto ou outros produtos nocivos à saúde".

Art. 2o Esta Resolução entra em vigor na data de sua publicação.

\section{Comentários:}

- Insere o amianto, tanto asbesto como crisotila, na classificação de resíduo perigoso Classe D. Isso vêm de encontro com a legislação de diversos países que condenam o uso desse material, por ser nocivo à saúde; 


\section{ANEXO II}

Modelos

Modelo de controle de geração e destinação

\section{FICHA DE REMOÇÃo E DESTINAÇÃO DE RESÍDUOS}

CONSTRUTORA

HUMAITÁ S.A.

EMPRESA: CONSTRUTORA HUMAITÁ S.A

DATA :

I I

OBRA:

ENDEREÇO :

\begin{tabular}{|l|l|l|l|l|}
\hline & TIPO DE RESIDUO & QUANT. & UNIDADE & VOLUME APROX. \\
\hline & ALVENARIA E CONCRETO & & & \\
\hline & GESSO & & & \\
\hline & MADEIRA & & & \\
\hline & PAPEL & & & \\
\hline & METAL & & & \\
\hline & PLÁSTICO & & & \\
\hline & TERRA & & & \\
\hline & OUTROS & & & \\
\hline
\end{tabular}

\section{TERMO DE RESPONSABILIDADE - RETIRADA DOS BAGS}

Assumo a responsabilidade pela devolução dos (quantidade retirada) bags ora retirados da obra, comprometendo-me a ressarcir o prejuízo decorrente da sua não devolução.

Responsável pela retirada e devolução

\section{TRANSPORTADOR}

NOME:

CNPJ / CPF :

TIPO DE VEÍCULO : PLACA :

DESTINATÁRIO: 
Modelo de Cadastro de Destinatário

CADASTRO DOS DESTINATÁRIOS DE RESÍDUOS

INFORMACÕES DO GERADOR

RAZÃO SOCIAL:

OBRA:

ENDEREÇO :

RESÍDUOS PASSÍVEIS DE DESTINAÇÃO

ALVENARIA E CONCRETO

GESSO

MADEIRA

PAPEL

METAL

PLÁSTICO

SOLO

OUTROS

\section{INFORMAÇÕES DO DESTINATÁRIO}

DATA DO CADASTRAMENTO:

RAZÃO SOCIAL:

ENDEREÇO :

NOME DO RESPONSÁVEL:

ATIVIDADE DO DESTINATÁRIO:

DESCRIÇÃO DA UTILIZAÇÃO DOS RESÍDUOS:

OUTRAS INFORMAÇÕES: 


\section{ANEXO III}

Questionário feito com funcionários do Edifício Piloto no início do Plano:

\section{QUESTIONÁRIO CONSTRUTORA HUMAITÁ S.A.}

Fase Inicial

Nome:

Data:

Cargo:

Chapa:

\section{Posicionamento na empresa:}

Quem são seus superiores diretos?

Quem são seus subalternos diretos?

Há quanto tempo trabalha na Humaitá? anos

\section{Com relação à gestão de resíduos:}

Qual sua função na gestão de resíduos?

Quanto tempo você dedica a essa função?

Que materiais você usa:

quantidade:

quantidade:

quantidade:

Qual é a dificuldade de tratar o entulho?

O que poderia facilitar seu trabalho? 


\section{ANEXO IV}

\section{Modelo de check list de limpeza e segregação}

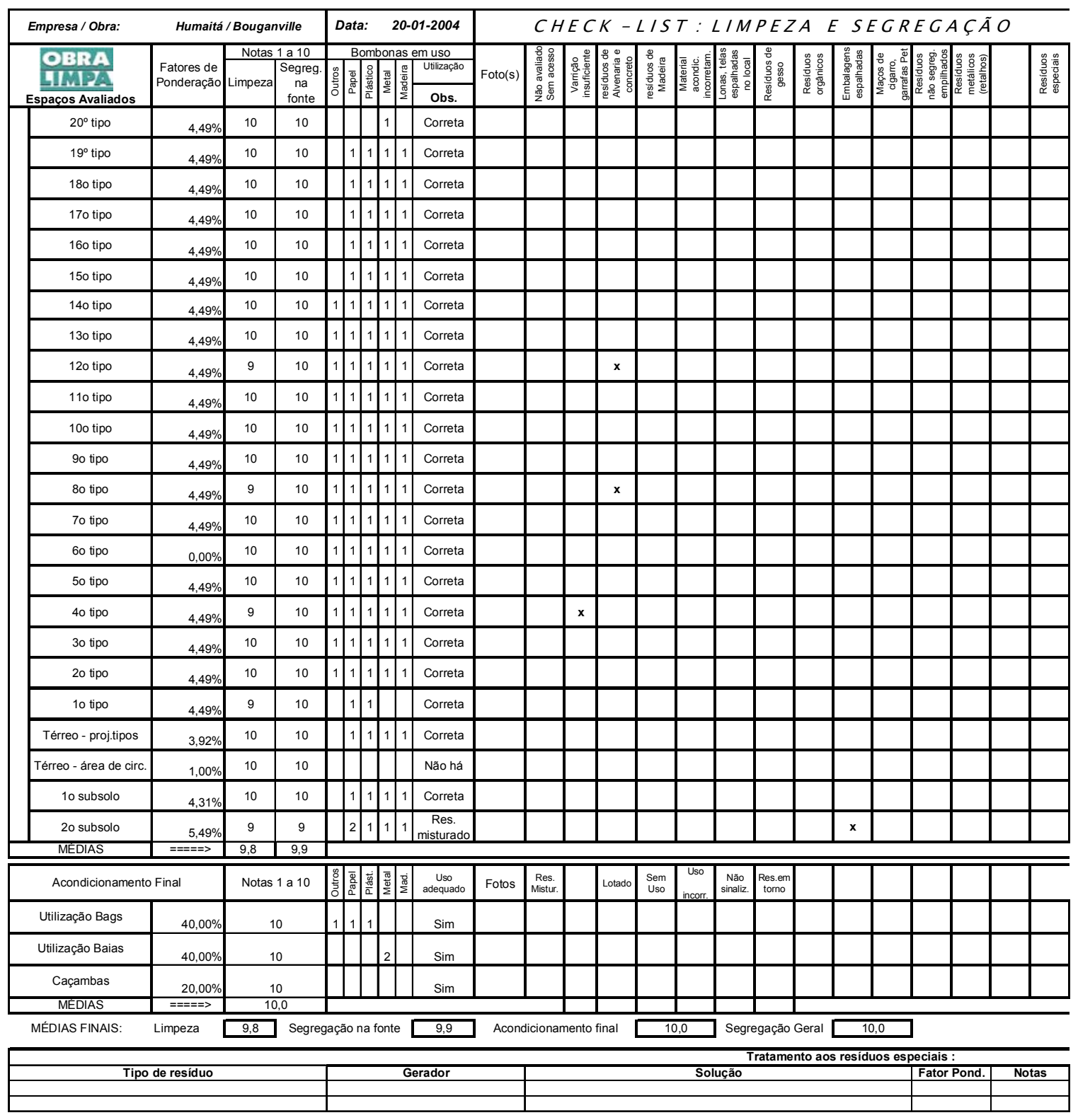




\section{ANEXO V}

Pesquisa realizada ao fim das atividades do primeiro Grupo de Trabalho a pedido do Sinduscon (CAMPOS, 2004).

Percepção de redução dos

resíduos na obra.

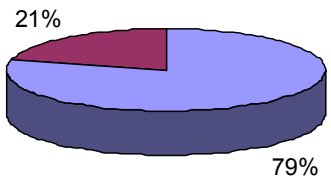

$\square$ Percebeu $\square$ Não percebeu

Mudança de cultura.

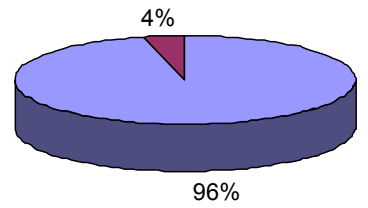

$\square$ Perceberam mudança $\square$ Não perceberam mudança

Gastos da obra.

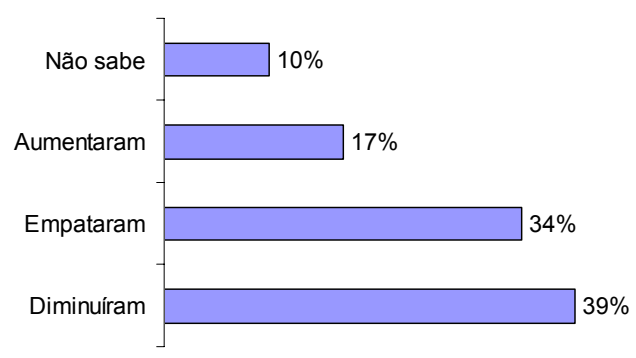

Fatores indutores para

redução dos resíduos.

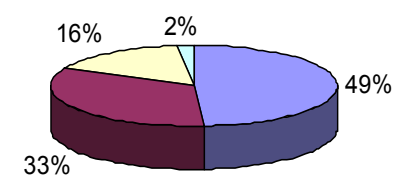

$\square$ Melhoria nos processos

$\square$ Reuso dos resíduos na própria obra

$\square$ Melhoria dos projetos

$\square$ Outros

Mudança de imagem da Construtora

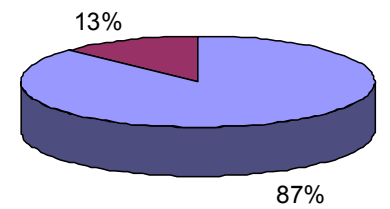

$\square$ Perceberam mudança $\square$ Não perceberam mudança

Principais problemas.

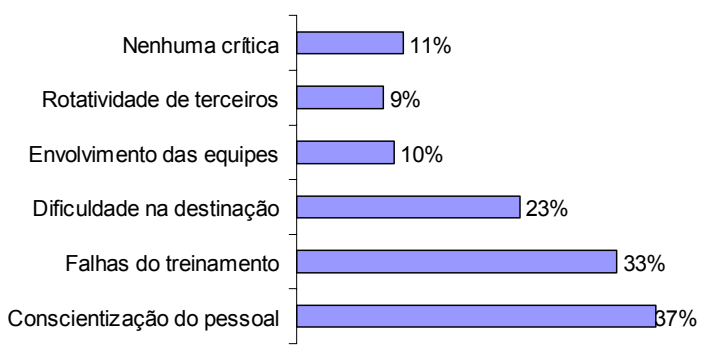




\section{ANEXO VI}

Modelo do Edifício Piloto 


\section{BIBLIOGRAFIA}

BALLOU, R. H. Logística empresarial. 11. ed. São Paulo, Ed. Atlas, 1993.

BARBOSA, E. Panorama do mercado de remoção dos resíduos da construção. Seminário Resíduos da Construção Civil: Nova política e o incentivo a novos negócios, 30 de junho de 2003.

BAZZO, W. A.; PEREIRA, L.T. Introdução à engenharia. Florianópolis, Ed. UFSC, 2000.

BIANCHI, L. Notes on dynamic vehicle routing - the state of the art. Technical Report IDSIA $05-01.2000$.

BIAZZI, L. F. de. Logística Reversa: o que é realmente e como é gerenciada. São Paulo, 2002. Dissertação (Mestrado) EPUSP, 2002.

BOAS, F. V. A evolução da indústria da construção civil na década de $\mathbf{9 0}$. Campinas, 1996 (Monografia) Unicamp, 1996.

BOGADO, J. G. M. Aumento da produtividade e diminuição de desperdícios na construção civil: um estudo de caso - Paraguai. Florianópolis, 1998. Dissertação (Mestrado) UFSC, 1998.

BORGES, A. C. Norma de desempenho de edificações: contribuição para a construção sustentável, Seminário 76 ENIC, 18 de outubro de 2004.

BRASIL, J. Os desafios da construção civil. Fiepa, 2004.

CARDOSO, L. Mesa redonda de desperdícios sólidos municipais: a visão do governo - Política Nacional de Resíduos Sólidos, 07 de março de 2003. 
CAMPOS, A. A. Programa de gestão ambiental de resíduos em canteiros de obras, Seminário 76 ENIC, 18 de outubro de 2004.

CBIC Câmara Brasileira da Industria da Construção. Retrospectiva 2004 e perspectivas para 2005: a conjuntura nacional e o setor da construção civil. Brasília, 2005.

CETESB Companhia de Tecnologia de Saneamento Ambiental. Decreto n. 47.397, de 4 de dezembro de 2002.

CHAROUX, O. Manual de produção científica, CECUR FAAP, São Paulo, outubro de 2002.

CHEN, Z.; LI, H. e WONG, C. T. C. An application of bar-code system for reducing construction wastes - Automation in Construction, 11, pp. 521-533, 2002.

CHURCHMAN, C. The systems approach, Ed. Delta, New York - USA, 1968.

CONSELHO NACIONAL DO MEIO AMBIENTE. Alterações na resolução CONAMA 307, de 20 de fevereiro de 2003.

CONSELHO NACIONAL DO MEIO AMBIENTE. Resolução CONAMA 307, de 5 de julho de 2002.

CONSELHO NACIONAL DO MEIO AMBIENTE. Resolução CONAMA 348, de 16 de agosto de 2004 .

CORSON, W. H. The global ecology handbook. Ed. Beacon Press, Boston, 1990.

De NEUFVILLE, R. Systems analysis for engineers and managers, Ed. McGraw-Hill, 1971

FIALHO, M. A. Plano de gestão sustentável para resíduos da construção civil e resíduos volumosos em São Paulo. Simpósio Resíduos da Construção Civil Nova política e o incentivo a novos negócios - Sinduscon SP 30 de junho de 2003. 
FRANCO, R. A. C. Processo de terceirização logística: uma abordagem de dinâmica de sistemas. São Paulo, 2005. Dissertação (Mestrado) EPUSP, 2005.

GORDON, G. System simulation. New Jersey. Ed Prentice-Hall, 1978.

GUALDA, N. Terminais de transportes: contribuição ao planejamento e ao dimensionamento operacional. São Paulo 1995. Tese (Livre Docência) EPUSP, 1995.

HUANG, W.; LIN, D.; CHANG, N. e LIN, K. Recycling of construction and demolition waste via a mechanical sorting process - Resources, Conservation and Recycling, 37, pp. 23-37, 2002.

JOHN, V. M. Reciclagem de resíduos na construção civil: Contribuição à metodologia de pesquisa e desenvolvimento. São Paulo, 2000(a). Tese (Livre Docência) EPUSP, 2000(a).

JOHN, V. M. e AGOPYAN, V. Reciclagem de resíduos da construção. Seminário Reciclagem de resíduos sólidos domiciliares - SMA/SP Maio de 2000(b).

KLANG, A.; VIKMAN, P. e BRATTEBO, H. Sustainable management of demolition waste: an integrated model for the evaluation of environmental, economical and social aspects - Resources, Conservation and Recycling, 38, pp. 317-334, 2003.

LIMPURB - Departamento de Limpeza Urbana da Secretaria de Serviços do Município de São Paulo. Lista de empresas de transportes de resíduos da construção civil em São Paulo, LIMPURB, julho de 2005.

LIMPURB - Departamento de Limpeza Urbana da Secretaria de Serviços do Município de São Paulo. Relação de áreas de Transbordo e Triagem de resíduos da Construção Civil com licença de funcionamento, Núcleo Gestor de Resíduo, julho de EOGEIRA, N. C. A construção no espelho, Ed. Pini, 1998. 
OWEN, S. H. e DASKIN, M. S. Strategic facility location: a review. European Journal of Operational Research, 111, pp. 423 - 447, 1998.

PARAGON. Introdução à simulação com ARENA. Paragon, 1998.

PCC EPUSP. Resíduos de construção e demolição PCC - Projeto Reciclagem de Resíduos como Materiais de Construção Civil, 2000.

PELLON, J. R. G. Planejamento da manutenção com enfoque logístico. São Paulo, 2004. Dissertação (Mestrado) EPUSP, 2004.

PIERDOMENICO, F. Modelo de gestão de serviço de limpeza urbana do município de São Paulo. Seminário Resíduos da Construção Civil Nova política e o incentivo a novos negócios - Sinduscon SP 30 de junho de 2003.

PINTO, T. P. Gestão de resíduos da construção civil: ações no estado de São Paulo. Painel sobre Resíduos da construção Civil - Sinduscon SP 22 de agosto de 2003.

PINTO, T. P. Metodologia para gestão diferenciada de resíduos sólidos da construção urbana. São Paulo 1999. Tese (Doutorado) EPUSP, 1999.

PINTO, T. P. Nova legislação e novas normas para o manejo e reciclagem de resíduos e para o uso de agregados reciclados. Resíduos da Construção Civil Nova política e o incentivo a novos negócios - Sinduscon SP 30 de junho de 2003.

PIRES, M. C. Painel sobre gestão de resíduos na construção - Painel sobre Resíduos da construção Civil - Sinduscon SP 22 de agosto de 2003.

POON, C. S. Management and recycling of demolition waste in Hong Kong - Waste Management \& Research, 15, pp. 561-572, 1997.

POON, C.S.; YU, A. T. W. e NG, Y. L. H. On-site sorting of construction and demolition waste en Hong Kong - Resources, Conservation and Recycling, 32, pp. 157-172, 2001. 
ROGERS, D. S.; LEMBKE, R. S. Going backwards: reverse logistics trends and practices. Ed. Reverse Logistics Executive Council, Nevada, 1998.

SALIBY, E. Repensando a simulação - A amostragem descritiva. São Paulo. Ed. Atlas, 1989.

SÃO PAULO ESTADO. Apresentação grupo de trabalho sobre política estadual de resíduos sólidos. Assembléia Legislativa de SP, 2003.

SÃO PAULO ESTADO. Projeto de lei 281/03.

SÃO PAULO ESTADO. Projeto de lei 611/03.

SÃO PAULO ESTADO. Substitutivo do projeto de lei 760/99.

SÃO PAULO PREFEITURA. Decreto n 42.217, de 24 de julho de 2002 - Publicado no DOM de 25 de julho de 2002(a).

SÃO PAULO PREFEITURA. Decreto n 46.594, de 03 de novembro de 2005 Publicado no DOM de 04 de novembro de 2005.

SÃO PAULO PREFEITURA. Lei n 10.315, de 30 de abril de 1987.

SÃO PAULO PREFEITURA. Lei n 13.298, de 16 de janeiro de 2002 - Publicado no DOM de 17 de janeiro de 2002(b).

SÃO PAULO PREFEITURA. Lei n 13.478, de 30 de dezembro de 2002 - Publicado no DOM de 02 de janeiro de 2003.

SARROUF, L. Gestão de resíduos na construção civil: a experiência do Sinduscon - SP, Seminário 76 ENIC, 18 de outubro de 2004. 
SCARDOELLI, L. S. Iniciativas de melhorias voltadas à qualidade e à produtividade desenvolvidas por empresas de construção de edificações. Porto Alegre 1995. Dissertação (Mestrado) UFRG, 1995.

SCHNEIDER, D. A. Áreas de transbordo e triagem, áreas de reciclagem, aterros para resíduos da construção civil. Seminário Resíduos da Construção Civil Nova política e o incentivo a novos negócios - Sinduscon SP 30 de junho de 2003.

SCHRIBER, T. J. An introduction to simulation using GPSS/H. Michigan. Ed. John Wiley \& Sons, 1991.

SECRETARIA DO MEIO AMBIENTE DO ESTADO DE SÃO PAULO. Resolução SMA 41, de 17-10-2002, publicada no DOE de 23 de outubro de 2002.

SERPEL, A. e ALARCÓN, L. F. Construction process improvement methodology for construction projects - International Journal of Project Management, Vol. 16, No 4, pp. 215-221, 1998.

SHAPIRO, J. F. Modeling the supply chain. Pacific Grove. Duxbury, 2001.

SHEN, L. Y. e TAM, V. W. Y. Implementation of environmental management in the Hong Kong construction industry - International Journal of Project Management, 20, pp. 535-543, 2002.

SHINGO, S. Study of Toyota production system from industrial engineering viewpoint. Tokyo: Japan Management Association, 1981

SILVA, V. G. Avaliação ambiental de edifícios: tendências internacionais e a realidade brasileira, Seminário 76 ENIC, 18 de outubro de 2004.

SKOYLES, E. R. e SKOYLES, j. Waste prevention on site. Londres. Ed. Mitchell, 1987. 
SOUZA, U. E. L. de. Como medir a produtividade da mão-de-obra na construção civil. VIII Encontro Nacional de Tecnologia do Ambiente Construído - ENTAC. Salvador, 2000.

SOUZA, U. E. L. de. Desenvolvimento e implantação de ferramentas de controle e melhoria da produtividade no uso dos recursos físicos. Seminário Internacional de Gestão e Tecnologia na Produção de Edifícios. São Paulo, 1997.

THOMAS, H. R. e YAKOUMIS, I. Factor model of construction productivity. Journal of Construction Engineering and Management, ASCE. V. 113 n. 4, 1987.

TRÄNKLER, J. O. V.; WALKER, I. e DOHMANN, M. Environmental impact of demolition waste: an overview on 10 years of research and experience - Waste Management, Vol. 16 Nos 1 - 3, pp. 21-26, 1996.

VALLIM, A. R. A. Localização de centros de distribuição de carga: Contribuições à modelagem matemática. São Paulo, 2004. Tese (Doutorado) EPUSP, 2004.

VASCONCELLOS, F. Ações do setor da construção civil na gestão de resíduos. Simpósio Resíduos da Construção Civil Nova política e o incentivo a novos negócios Sinduscon SP 30 de junho de 2003.

VASCONCELLOS, F. Ações do setor da construção civil. Painel sobre Resíduos da construção Civil - Sinduscon SP 22 de agosto de 2003.

YOST, P. A. e HALSTEAD, J. M. A methodology for quantifying the volume of construction waste - Waste Management \& Research, 14, pp. 453-461, 1996. 